\title{
Ontwikkelingen in het leerlingwezen tot 2000
}

Citation for published version (APA):

Borghans, L., \& Smits, W. (1996). Ontwikkelingen in het leerlingwezen tot 2000. Researchcentrum voor Onderwijs en Arbeidsmarkt, Faculteit der Economische Wetenschappen. ROA Reports No. 006 https://doi.org/10.26481/umarep.1996006

Document status and date:

Published: 01/01/1996

DOI:

10.26481/umarep.1996006

Document Version:

Publisher's PDF, also known as Version of record

\section{Please check the document version of this publication:}

- A submitted manuscript is the version of the article upon submission and before peer-review. There can be important differences between the submitted version and the official published version of record.

People interested in the research are advised to contact the author for the final version of the publication, or visit the DOI to the publisher's website.

- The final author version and the galley proof are versions of the publication after peer review.

- The final published version features the final layout of the paper including the volume, issue and page numbers.

Link to publication

\footnotetext{
General rights rights.

- You may freely distribute the URL identifying the publication in the public portal. please follow below link for the End User Agreement:

www.umlib.nl/taverne-license

Take down policy

If you believe that this document breaches copyright please contact us at:

repository@maastrichtuniversity.nl

providing details and we will investigate your claim.
}

Copyright and moral rights for the publications made accessible in the public portal are retained by the authors and/or other copyright owners and it is a condition of accessing publications that users recognise and abide by the legal requirements associated with these

- Users may download and print one copy of any publication from the public portal for the purpose of private study or research.

- You may not further distribute the material or use it for any profit-making activity or commercial gain

If the publication is distributed under the terms of Article $25 \mathrm{fa}$ of the Dutch Copyright Act, indicated by the "Taverne" license above, 
Ontwikkelingen in het leerlingwezen tot 2000

ROA-R-1996/6

Lex Borghans

Wendy Smits

Researchcentrum voor Onderwijs en Arbeidsmarkt

Faculteit der Economische Wetenschappen en Bedrijfskunde

Rijksuniversiteit Limburg

Maastricht, augustus 1996 
ISBN 90-5321-184-5 


\section{Inhoudsopgave}

blz.

Voorwoord

1 Inleiding

2 Het duale onderwijssysteem 5

2.1 Inleiding 5

2.2 Vraag naar leerlingen vanuit het bedrijfsleven 5

2.3 Leren of werken? 8

2.4 Arbeidsmarktpositie van schoolverlaters uit het duale onderwijs 9

3 Huidige stand van zaken in het leerlingwezen 11

$\begin{array}{ll}3.1 \text { Inleiding } & 11\end{array}$

3.2 De leerlingstelsels $\quad 11$

$\begin{array}{ll}\text { 3.3 De praktijkcomponent } & 19\end{array}$

3.4 Conjunctuurgevoeligheid van de instroom $\quad 27$

4 Schoolverlaters van de primaire leerlingwezenopleidingen 31

$\begin{array}{ll}4.1 \text { Inleiding } & 31\end{array}$

4.2 Schoolverlaters van de primaire opleidingen 31

4.3 Actuele arbeidsmarktpositie van gediplomeerde schoolverlaters
uit het leerlingwezen

5 Verschillen in arbeidsmarktpositie tussen schoolverlaters uit

het leerlingwezen, KMBO en MBO 41

5.1 Inleiding 41

5.2 Verschillen in arbeidsmarktpositie $\quad 41$

5.3 Aansluiting opleiding en beroep $\quad 47$

6 De instroom van schoolverlaters uit het leerlingwezen, 1995-2000 51

6.1 Inleiding 51

6.2 De arbeidsmarktinstroom van gediplomeerde schoolverlaters

per landelijk orgaan $\quad 53$

7 De vraag naar schoolverlaters uit het leerlingwezen $\quad 57$

$\begin{array}{ll}7.1 \text { Inleiding } & 57\end{array}$

7.2 Het verbijzonderen van de vraagprognoses $\quad 57$

7.3 Het beroepsdomein van MBO- en LLW-schoolverlaters 59

7.4 Baanopeningen voor MBO en LLW verbijzonderd naar beroepsdomein 66 
8 Confrontatie van vraag en aanbod $\quad 71$

$\begin{array}{ll}8.1 \text { Inleiding } & 71\end{array}$

$\begin{array}{ll}\text { 8.2 De vraag vanuit het gezamenlijke beroepsdomein } & 71\end{array}$

8.3 Arbeidsmarktperspectieven voor LLW'ers en MBO'ers volgens drie $\begin{array}{ll}\text { scenario's } & 74\end{array}$

9 Conclusies $\quad 81$

$\begin{array}{ll}\text { Literatuur } & 95\end{array}$

Appendix A Lijst met afkortingen landelijke organen voor het leerlingwezen $\quad 97$

Appendix B Opleidingsrichtingen uit hoofdstuk 4 99

Appendix C Verbijzonderen van ROA arbeidsmarktprognoses voor het MBO/LLW 109

$\begin{array}{ll}\text { Appendix D De beroepsdomeinen } & 117\end{array}$ 


\section{Voorwoord}

In dit rapport wordt een overzicht gegeven van de huidige en toekomstige positie van het leerlingwezen op de arbeidsmarkt. De actuele arbeidsmarktpositie van schoolverlaters uit het leerlingwezen wordt vergeleken met de positie van schoolverlaters uit het MBO en KMBO. Daarnaast worden de werkgelegenheidsontwikkelingen zoals die beschreven zijn in De arbeidsmarkt naar opleiding en beroep tot 2000 (ROA, 1995a, b) toegespitst op het leerlingwezen.

Het onderzoek is uitgevoerd in opdracht van het Ministerie van Onderwijs, Cultuur en Wetenschappen. De auteurs danken drs. A.G.M. Matheeuwsen voor haar bijdrage aan hoofdstuk 6 van het rapport. Verder zijn zij dank verschuldigd aan prof. dr. J.A.M. Heijke en dr. A. de Grip voor hun commentaar. Tenslotte willen zij mevrouw A. Wijnands van het Sigma College in Maastricht bedanken voor haar informatie over de praktijk van het leerlingwezen. 



\section{Inleiding}

In de rapporten van de commissie Wagner in het midden van de jaren tachtig werd een sterke uitbreiding bepleit van het beroepsonderwijs dat is opgezet via het zogenaamde duale systeem, waarbij leren en werken worden gecombineerd. Door de verdubbelingsoperatie in de jaren tachtig is het aantal leerovereenkomsten sindsdien sterk toegenomen. Momenteel is ongeveer een kwart van de arbeidsmarktinstroom van schoolverlaters op middelbaar niveau afkomstig uit het leerlingwezen. De laatste jaren is de instroom in het leerlingwezen echter weer onder druk komen te staan. Enerzijds heeft aan de vraagkant de slechte conjuncturele situatie een negatieve invloed op de verdere ontwikkeling van het leerlingwezen. Anderzijds loopt aan de aanbodkant de uitstroom uit de opleidingen die traditioneel leverancier waren van het leerlingwezen (met name VBO technisch) sterk terug (De Grip e.a., 1993).

De commissie Van Veen heeft opnieuw de discussie over de positionering van het leerlingwezen ten opzichte van de (K)MBO leertrajecten aangezwengeld (Commissie Dualisering, 1993). Het leerlingwezen lijkt voor vele vormen van vakarbeid een geschikte methode om leerlingen een scholing te geven die aan de ene kant goed aansluit bij de kennis en vaardigheden die nodig zijn voor hun latere beroepsuitoefening (de 'beroepsvorming'), maar die hieraan aan de andere kant ook in voldoende mate een (vak)theoretische scholing koppelt. Een leerovereenkomst is immers in de eerste plaats bedoeld om kennis te verwerven, die van belang is gedurende de gehele loopbaan, en is geen werkplek waarbij het de bedoeling is onmiddellijk reeds zo produktief mogelijk te zijn. Daardoor draagt het leerlingwezen in belangrijke mate bij aan het bereiken van een startkwalificatie, zodat de leerlingen met voldoende kennis de arbeidsmarkt betreden ${ }^{1}$. In de recente beleidsplannen is daarom voorgenomen om het leerlingwezen een nieuwe stimulans te geven. Gestreefd wordt naar een verhoging van de instroom in het primair leerlingwezen van 20.000 personen per jaar (Ministerie van Sociale Zaken en Werkgelegenheid, 1993). Het 'Project Extra Impuls Leerlingwezen' (PEIL) gaf een aanzet voor deze verdere stimulering van de groei van het leerlingwezen (PEIL, 1994).

In het onlangs verschenen rapport De arbeidsmarkt naar opleiding en beroep tot 2000 (ROA, $1995 a, b)$ wordt getoond dat de doorstroom van leerlingen met alleen een VBO-, MAVO-, of HAVO-diploma of zelfs zonder enige voltooide opleiding, naar MBO of leerlingwezen van groot belang is voor een betere aansluiting tussen onderwijs en arbeidsmarkt. Het mes snijdt hierbij aan twee kanten. Aan de ene kant

1. Van der Velden en Lodder (1995) laten zien dat het leerlingwezen met name voor bepaalde leerlingen een zeer geschikte route lijkt te zijn. 
blijken schoolverlaters met een MBO/LLW-diploma betere perspectieven op de arbeidsmarkt te hebben. Aan de ander kant wordt door deze doorstroom het aanbod van schoolverlaters zonder deze 'startkwalificatie' verminderd, waardoor er per saldo meer ruimte op de arbeidsmarkt overblijft voor de groep die nooit dit kwalificatieniveau zal behalen. Dit betekent dat de vraag naar laag- of ongeschoolde arbeid ook terecht komt bij hen die werkelijk afhankelijk zijn van deze banen. Vanuit dit perspectief werpt het gevoerde beleid om de doorstroom naar (K)MBO en leerlingwezen te bevorderen nu reeds zijn vruchten af.

Bij de realisatie van een verdere groei van het leerlingstelsel doen zich twee problemen voor. In de eerste plaats zijn de groeimogelijkheden bij het leerlingwezen, evenals bij andere opleidingen, sterk bepaald door de groei van het instroompotentieel. In De Grip e.a. (1993) komt duidelijk naar voren dat bij ongewijzigd beleid de instroom een sterk belemmerende factor zal worden voor de gewenste ontwikkeling van de leerlingenaantallen in het leerlingwezen. Dit wordt veroorzaakt door het feit dat het leerlingwezen thans met name op technisch opgeleiden op VBO-niveau gericht is. Door gerichte beleidsmaatregelen die de instroom van andere, niet traditioneel op het leerlingwezen gerichte groepen bevorderen en een substantiële rendementsverhoging bewerkstelligen, kunnen de streefcijfers van de meeste organen voor het leerlingwezen toch gerealiseerd worden.

Een momenteel actueel probleem is dat de groeimogelijkheden van het leerlingwezen worden beperkt door de beschikbaarheid van leerlingplaatsen in het bedrijfsleven. Het aantal beschikbare plaatsen is afhankelijk van de mogelijkheden een leerling bij een bedrijf te plaatsen. Hierdoor wordt de capaciteit van dit duale leersysteem conjunctuurgevoelig. Hier komt bij dat de leerling terechtkomt in een praktijksituatie die niet volledig door de school wordt bepaald. Voor de beroepsvorming is de leerling in hoge mate afhankelijk van het bedrijf. In vergelijking met andere leersystemen zal het hierdoor moeilijker zijn het leerniveau en het numerieke rendement van de leerarbeidsplaatsen op peil te houden.

Hoewel het leerlingwezen zich voor een aanzienlijk deel richt op hetzelfde beroepsdomein als het MBO zijn er twee wezenlijke verschillen tussen beide onderwijsvormen. Ten eerst is het leerlingwezen veel sterker beroepsgericht dan het MBO. Dit betekent dat het voor een verdere ontwikkeling van het leerlingwezen van groot belang is om inzicht te hebben in de verschuivingen aan de vraagkant van de arbeidsmarkt. Ten tweede impliceert de duale leervorm van het leerlingwezen dat leerlingen voor hun ontwikkeling afhankelijk zijn van de werksituatie waarin zij terecht komen. Voor een optimale invulling van het leeraspect van een leer-arbeidsovereenkomst, maar ook voor het arbeidsmarktperspectief op langere termijn, lijkt het cruciaal dat ook de werkgever een goede vakopleiding van zijn leerlingen belangrijk vindt. 
In dit rapport wordt ingegaan op de positie die het leerlingwezen inneemt op de arbeidsmarkt. Doel van de studie is om te verkennen welke arbeidsmarktperspectieven de verschillende opleidingsrichtingen binnen het leerlingwezen de komende vijf jaar hebben. Hiertoe worden de werkgelegenheidsontwikkelingen zoals die beschreven staan in De arbeidsmarkt naar opleiding en beroep tot 2000 (ROA, $1995 \mathrm{a}, \mathrm{b})$ ook toegespitst op het leerlingwezen. Omdat het perspectief van het leerlingwezen sterk afhangt van de positie die de leerling tijdens de leer-arbeidsovereenkomst heeft, wordt ook de actuele positie van schoolverlaters uit het leerlingwezen in ogenschouw genomen. Hierbij wordt een vergelijking gemaakt met het MBO en KMBO. Ten slotte worden de vraag- en aanbodstromen tegenover elkaar gesteld en wordt op basis van verschillende aannames over de onderlinge positie van MBO'ers en LLWers het verwachte arbeidsmarktperspectief in het jaar 2000 voor beide groepen geschetst.

De cijfers over de actuele positie van het leerlingwezen zijn gebaseerd op de RUBS-schoolverlatersenquête. Dit is een schriftelijke enquête onder schoolverlaters van het $A V O, V B O$ en $M B O$, ruim drie-kwart jaar na afstuderen. De enquête bevat informatie over personen die na het verlaten van het regulier dagonderwijs een opleiding in het kader van het leerlingwezen zijn gaan volgen. In 1994 zijn voor het eerst ook schoolverlaters van het Beroepsbegeleidend Onderwijs (BBO) ondervraagd. Het BBO vormt het theoriegedeelte van een opleiding in het kader van het leerlingwezen.

Het aantal waarnemingen is voor sommige organen en opleidingsrichtingen echter vrij klein. Om toch voor zoveel mogelijk organen cijfers te kunnen presenteren, is een ondergrens van 15 waarnemingen gekozen. Als het aantal waarnemingen minder is dan 15 wordt in de tabellen een '-' afgedrukt. Omdat deze ondergrens vrij laag genomen is, is er voor gekozen om in de meeste tabellen de percentages op vijftallen af te ronden. 


\section{Het duale onderwijssysteem}

\subsection{Inleiding}

Het leerlingwezen is, sterker nog dan het reguliere beroepsonderwijs, gericht op het aanleren van direct toepasbare vakkennis, die later nodig is voor het adequaat uitoefenen van een beroep. Deze sterke band heeft zowel voor- als nadelen. Een voordeel is uiteraard dat de inhoud van het onderwijsprogramma zeer nauw verbon den is met de werkpraktijk. Door de beroepspraktijkvorming heeft de school een directe relatie met het bedrijfsleven in haar omgeving. Daarmee wordt de afstemming bevorderd en vinden leerlingen sneller een vaste plaats op de arbeidsmarkt, soms al tijdens de opleiding. Dit betekent een verbetering van de aansluiting tussen onderwijs en arbeidsmarkt en dat maakt het leerlingwezen voor vele leerlingen die een praktijkgerichte instelling hebben een belangrijk alternatief voor het meer theoretisch gerichte Middelbaar Beroepsonderwijs. Een nadeel van een dergelijk systeem komt echter tot uitdrukking in de uitvoering. Juist vanwege deze nauwe band met de beroepsuitoefening kan het realiseren van de gewenste aantallen leerlingplaatsen worden belemmerd door de beperkte opleidingsmogelijkheden die het bedrijfsleven biedt.

Verder ontstaat er vanwege het duale karakter van het onderwijssysteem een mogelijke spanning tussen het leerbelang en de wenselijkheid de leerlingen produktief in te zetten. Als voor de werkgever een hoge produktiviteit belangrijker is dan de meer lange termijngerichte scholingseffecten kan de effectiviteit van de leersituatie in gevaar komen.

In dit hoofdstuk wordt kort ingegaan op de spanningen die besloten liggen in het leerlingwezensysteem. Deze theoretische uitgangspunten dienen ertoe de empirische bevindingen in de latere hoofdstukken beter in perspectief te kunnen plaatsen. De wijze waarop deze spanningen zich manifesteren - de wijze waarop de leerarbeidsplaats is ingebed in de organisatie - is naast de verwachte aanbod- en werkgelegenheidsontwikkelingen bepalend voor het arbeidsmarktperspectief van de leerlingwezenopleidingen.

\subsection{Vraag naar leerlingen vanuit het bedrijfsleven}

Een belangrijk verschil tussen het voltijds dagonderwijs en het leerlingwezen is dat in het voltijds dagonderwijs de leerlingen pas geconfronteerd worden met de arbeidsmarkt als ze de opleiding voltooid hebben, terwijl voor het leerlingwezen een leer-arbeidsplaats in principe reeds bij aanvang van de opleiding verworven moet worden. Dit heeft als consequentie dat de problematiek van de aansluiting tussen 
onderwijs en arbeidsmarkt voor een deel in de tijd naar voren wordt geschoven. Of dit vanuit arbeidsmarktoptiek een verbetering is hangt af van twee factoren.

Ten eerste is het de vraag of de aansluitingsproblematiek na afloop van de opleiding in het kader van het leerlingwezen daadwerkelijk kleiner wordt. Als het arbeidscontract gelijktijdig met de leerovereenkomst afloopt, en als de totstandkoming van de leer-arbeidsovereenkomst niet voortkwam uit een concrete behoefte aan gekwalificeerd personeel, hoeft een gediplomeerde leerling niet minder problemen te hebben bij het vinden van werk, dan iemand met een voltijdse dagopleiding. Omgekeerd zijn uiteraard de beste garanties voor een goede aansluiting na de opleiding, concrete intenties van de werkgever om iemand in dienst te houden. Ook goede afspraken binnen een bedrijfstak zouden in principe voor een dergelijke afstemming kunnen zorgen. Werkgevers moeten dus vooruitdenken en via het leerlingwezen in hun toekomstige behoefte aan gekwalificeerd personeel voldoen. Als, bijvoorbeeld vanwege conjuncturele schommelingen, de toekomstige behoefte sterk afwijkt van wat nodig is bij de huidige produktie-omvang, kunnen zich hierbij overigens nog moeilijke organisatorische problemen voordoen. Bij een aantal organen voor het leerlingwezen worden dergelijke discrepanties in de tijd op bedrijfstakniveau aangepakt.

Een tweede vraag met betrekking tot het naar voren schuiven van de confrontatie van leerlingen met de arbeidsmarkt is of - zelfs als er alleen plaatsen beschikbaar komen die goed aansluiten op de latere vraag - leerlingen die willen deelnemen aan het leerlingwezen hun richtingkeuze aanpassen aan de vraagontwikkelingen. Als bij een te groot aanbod van leerlingen maatregelen worden genomen om de vraag naar leerlingen te vergroten, bijvoorbeeld door het subsidiëren van leer-arbeidsplaatsen, of als leerlingen die geen leer-arbeidsplaats vinden uitwijken naar een vergelijkbare richting op het $(\mathrm{K}) \mathrm{MBO}$, wordt de aansluiting met de arbeidsmarkt niet werkelijk bevorderd door het leerlingwezen.

Cruciaal voor de positie die een leerling na het behalen van het diploma heeft is de vraag waarom een werkgever een leer-arbeidsplaats instelt. Een bedrijf kan verschillende redenen hebben om een leerling in dienst te nemen. Ten eerste kan een bedrijf een leerling zien als een goedkope arbeidskracht. Het bedrijf vergelijkt dan de kosten en de produktiviteit van leerlingen met dat van gekwalificeerd personeel (zie Björn, 1995). De belangrijkste kostenpost vormen de directe kosten, zoals de loonkosten, leervergoedingen en onkostenvergoedingen. Andere kosten voor het bedrijf zijn de begeleidingskosten, kosten zoals afdrachten en contributies aan opleidingsfondsen, kosten van de fysieke infrastructuur en gebruik van produktiemid- 
delen en materialen. Tegenover deze kosten staan subsidies en tegemoetkomingen die bedrijven ontvangen als ze een leerling in dienst nemen².

Een bedrijf zal vanuit deze optiek eerder leerlingen aannemen als de directe kosten, zoals het loon, de begeleidingskosten of de overige kosten lager zijn en de subsidies hoger zijn. Als de lonen van het gekwalificeerde personeel toenemen terwijl de Ionen voor leerlingen gelijk blijven zal de vraag naar leerlingen eveneens toenemen.

Een probleem van deze overweging om een leer-arbeidsplaats in te stellen is dat de behoefte van de werkgever in dat geval niet gekoppeld is aan een toekomstige behoefte aan gekwalificeerd personeel. Dit betekent dat de vraag naar leerlingen geenszins een behoefte aan de opleiding weerspiegelt. Stimuleren van opleidingsplaatsen, bijvoorbeeld door een loonkostensubsidie, leidt in dit geval alleen tot een goede arbeidsmarktpositie als de omvang van de vraag vanuit de bedrijfstak of door de overheid wordt vastgesteld. Een stimulans kan echter zelfs averechts werken omdat leerlingen, vanwege hun lage kosten, een substituut kunnen vormen voor gekwalificeerd personeel. Een verlaging van de kosten van leerlingen kan daardoor een lagere vraag naar gekwalificeerd personeel betekenen.

Een tweede mogelijke reden om leerlingen in dienst te nemen is de wens van een bedrijf om zelf personeel op te leiden. Op deze wijze is het bedrijf verzekerd van voldoende gekwalificeerd personeel in de toekomst. Bovendien heeft het bedrijf de kans om zelf een stempel op de opleiding te drukken. lemand die in het bedrijf is opgeleid beschikt over bedrijfsspecifieke vakkennis en vaardigheden. Een bedrijf ziet het opleiden van een leerling dan als een investering.

In dat geval worden de baten van het bedrijf vergroot met de verwachte opbrengst van de investering. Voor een leerling is het voordeel dat hij er van uit kan gaan dat het bedrijf - zeker als hij voldoet in zijn functie - het voornemen heeft hem ook na de opleiding in dienst te houden. In feite wordt de leer-arbeidsovereenkomst in dit geval een gemeenschappelijke investering van leerling en werkgever waardoor voor een groot deel ook hun belangen parallel komen te lopen.

Een bedrijf loopt echter het risico dat een leerling na het voltooien van de opleiding bij een ander bedrijf gaat werken. Dit risico is groter naarmate voor het beroep waarvoor de leerling wordt opgeleid bedrijfsspecifieke kenmerken minder van belang zijn. Als de opleiding alleen waarde heeft in het eigen bedrijf dan is de leerling gebonden aan het leerbedrijf. Als een opleiding algemeen erkend is en

2. De Vries en Heere (1994) geven een uitgebreid overzicht van de directe kosten en opbrengsten voor verschillende opleidingen in het leerlingwezen. 
bedrijfsspecifieke kennis van minder belang is - wat uiteraard juist het streven is van het leerlingwezen - dan heeft de leerling meer mogelijkheden om na het voltooien van de opleiding een andere baan te gaan zoeken (zie Van Smoorenburg en Van der Velden, 1995). De verwachte toekomstige opbrengsten voor het bedrijf worden dan minder, omdat de verwachte tijd dat een leerling bij het bedrijf blijft na het voltooien van de opleiding korter is en de meerwaarde van iemand die in het eigen bedrijf is opgeleid kleiner is. In dat geval is het voor het bedrijf ook gunstiger om iemand in dienst te nemen die bij een ander bedrijf de opleiding heeft gevolgd. Het bedrijf hoeft dan niet zelf de kosten van het opleiden op zich te nemen. Dit leidt tot het zogenaamde 'free riders' gedrag. Bedrijven hebben er baat bij dat er voldoende leerlingen worden opgeleid maar hebben er geen baat bij om zelf leerlingen op te leiden als andere bedrijven al leerlingen opleiden.

Verder lijkt relevant te zijn welke omvang het bedrijf heeft vergeleken met zijn concurrenten in de omgeving. Een groot bedrijf zal relatief minder last hebben van vertrekkende medewerkers en heeft daarbij ook veel meer mogelijkheden de opleiding af te stemmen op de toekomstige behoefte aan gekwalificeerd personeel. Bij een klein bedrijf hangt deze behoefte immers sterk af van toevalligheden, zoals het vertrek van een ervaren medewerker en bestaat er niet veel speling in de tijd om nieuwe vakkrachten aan te trekken. Voor kleine bedrijven is het daarom relatief aantrekkelijk om niet zelf te investeren in de opleiding van vakkrachten, maar deze te werven op de markt. Een gecoördineerde aanpak op bedrijfstakniveau kan mogelijk dit free-riders-probleem oplossen. In verschillende sectoren bestaan reeds samenwerkingsverbanden, de GOA's (Centra Gemeenschappelijke Opleidings-Activiteiten). In een GOA-constructie dragen aangesloten bedrijven gezamenlijk zorg voor de praktijkopleiding. De GOA treedt op als patroon, werft de leerlingen, betaalt loon en leervergoedingen en leent de leerlingen uit aan de betrokken bedrijven.

\subsection{Leren of werken?}

In de praktijk zullen zowel directe baten (de huidige produktiviteit van een leerling) als toekomstige baten (toekomstige produktiviteit van de leerling) een rol spelen in de beslissing om leerlingen aan te nemen. Als voornamelijk directe baten een rol spelen, bestaat het gevaar dat werkgevers niet zozeer in de opleiding van de leerling, maar meer in de directe produktiviteit van de leerling geïnteresseerd zijn. Naast een spanning tussen vraag en aanbod op de arbeidsmarkt, kan er daarom ook een spanning tussen werken en leren ontstaan op de leer-arbeidsplaats. Dat leidt mogelijk tot een verminderde kwaliteit van de opleiding. De essentie van het leerlingwezen is dat men leert door in een concrete werksituatie te functioneren. De mate waarin een leerling vakkennis opdoet wordt echter bepaald door de aard van de werkzaamheden die men hem laat verrichten en de inzet van ervaren collega's in de begeleiding. De combinatie van de werkzaamheden die optimaal is voor de 
kennisverwerving, hoeft uiteraard niet het meest effectief te zijn voor de onmiddellijke produktiviteit. Killingsworth (1982) onderscheidt daarom 'training on the job' van 'learning by doing'. Een bedrijf dat de werkomgeving optimaal benut om een leerling ervaring op te laten doen, zorgt voor 'training on the job'. Doorgaans gaat dit ten koste van de produktiviteit, dus in feite zijn er kosten aan verbonden. Als een bedrijf alleen oog heeft voor de directe produktiviteit zal een leerling toch ervaring op doen. In dat geval spreekt Killingworth van 'learning by doing'. Deze kennisverwerving zal echter geringer zijn dan bij 'training on the job'. In plaats van een produktiviteitsverlies is er in dit geval sprake van leerverlies. Bovendien zal de kennis die men opdoet meer bedrijfsspecifiek en minder algemeen zijn.

Verder kan ook een laag numeriek rendement van het leerlingwezen voortkomen uit het relatief hoge belang van directe produktiviteit en een gering belang van de opleidingscomponent. In dat geval heeft het behalen van het diploma immers weinig betekenis en zullen leerlingen makkelijker hun leer-arbeidsplaats opgeven als ze elders beter betaald werk kunnen krijgen. De Grip e.a. (1993) tonen dat het numeriek rendement van de verschillende leerstelsels nogal uiteen loopt. Juist bij richtingen waar het diploma van groot belang lijkt te zijn voor de verdere loopbaan, zoals bij de grafische opleidingen, blijkt een hoog percentage van de leerlingen de opleiding met een diploma te voltooien.

Ook met betrekking tot de spanning tussen leren en werken kan betrokkenheid van de school of een orgaan voor het leerlingwezen een corrigerende werking hebben. In de praktijk vindt dit plaats doordat de organen eisen stellen aan de aard van de activiteiten die een leerling dient te verrichten.

\subsection{Arbeidsmarktpositie van schoolverlaters uit het duale onderwijs}

De arbeidsmarktpositie van schoolverlaters uit het leerlingwezen is, zoals reeds eerder werd opgemerkt, wezenlijk anders dan die van schoolverlaters uit het voltijds dagonderwijs. Leerlingen in het leerlingwezen betreden in principe de arbeidsmarkt op het moment dat zij met hun opleiding beginnen. De aansluitingsproblematiek speelt dus op het moment dat men aan de opleiding begint en mogelijk minder op het moment dat men de opleiding verlaat.

Zoals in de vorige paragrafen werd aangegeven, is het cruciaal voor de arbeidsmarktpositie van een gediplomeerde schoolverlater uit het leerlingwezen welke motieven het bedrijf heeft gehad om een leerling in dienst te nemen. Indien de toekomstige baten een belangrijke rol hebben gespeeld voor het bedrijf dan is de arbeidsmarktpositie waarschijnlijk beter, dan wanneer met name directe baten een rol hebben gespeeld. In het eerste geval streeft het bedrijf ernaar om de leerling na het voltooien van de opleiding in dienst te houden. In het laatste geval lopen leer- 
lingen meer risico hun baan te verliezen als de opleiding is afgerond omdat de reden van het dienstverband - de relatief lage kosten - wegvalt. Dit betekent dat deze leerlingen een grote kans hebben op zoek te moeten naar een andere baan, terwijl juist bij hen de voorwaarden voor een goede opleiding het minst aanwezig waren. Bedrijven met een duidelijk investeringsdoel zullen in principe zelf de gediplomeerde leerling in dienst willen nemen. Alleen als de prestaties tegen blijken te vallen, zal er reden zijn het dienstverband niet te verlengen. Het feit dat leerlingen niet bij een bedrijf in dienst zijn gebleven is daarbij mogelijk ook nog een negatief arbeidsmarktsignaal voor andere bedrijven. Andere werkgevers kunnen hieruit immers concluderen dat het bedrijf van herkomst ze niet voldoende produktief vindt. Dit verslechtert hun arbeidsmarktpositie nog verder.

Voor de arbeidsmarktpositie van het leerlingwezen moet daarom onderscheid gemaakt worden tussen degenen die bij hun huidige werkgever kunnen blijven werken en zij die na afloop van de opleiding op zoek moeten naar een andere baan. LLW-schoolverlaters in bedrijfssectoren waar de toekomstige baten de belangrijkste reden zijn voor bedrijven om leerlingen op te leiden zullen daardoor weinig concurrentie ondervinden van schoolverlaters van het MBO en KMBO. Schoolverlaters uit het MBO en KMBO moeten nog werk zoeken, terwijl de schoolverlaters uit het leerlingwezen in de regel al werk hebben. Leerlingen die na het voltooien van de opleiding niet bij hetzelfde bedrijf kunnen blijven werken, ondervinden wel meer concurrentie van MBO'ers en KMBO'ers.

De eerste tijd na het afstuderen hebben veel schoolverlaters van het leerlingwezen waarschijnlijk een iets betere arbeidsmarktpositie dan schoolverlaters van het KMBO en MBO. KMBO'ers en MBO'ers hebben, in tegenstelling tot schoolverlaters uit het leerlingwezen, nog geen binding met de arbeidsmarkt op het moment dat ze de school verlaten. Na enige tijd, wanneer de MBO'ers ook werk hebben, zullen LLWers wel concurrentie gaan ondervinden van MBO'ers (Van der Velden en Lodder, 1995). Met name MBO'ers hebben naar verwachting meer algemene vaardigheden aangeleerd en zullen daardoor ook beter in staat zijn om nieuwe vaardigheden aan te leren. Mensen met een leerlingwezenopleiding bezitten daarentegen meer specifiek vaktechnische vaardigheden en zullen minder goed in staat zijn om nieuwe vaardigheden bij te leren. Zeker in tijden van sterke technologische veranderingen zal dit zijn weerslag hebben op de arbeidsmarktmogelijkheden. 


\title{
3 Huidige stand van zaken in het leerlingwezen
}

\author{
3.1 Inleiding
}

In dit hoofdstuk wordt een beeld gegeven van de huidige stand van zaken in het leerlingwezen. Er zal met name worden ingegaan op de verschillen tussen de leerlingstelsels. Het accent zal hierbij liggen op de primaire leerlingwezenopleidingen. De leerlingstelsels zijn over het algemeen sterk aan een bedrijfssector gekoppeld. Ontwikkelingen in de bedrijfssectoren zullen daarom hun weerslag vinden in de inrichting van de opleidingen en in de beschikbaarheid van leer-arbeidsplaatsen. Hoe groot de invloed is van sectorale ontwikkelingen op de leerlingwezenopleidingen is mede afhankelijk van de wijze waarop de praktijkcomponent in een bepaald leerlingstelsel geregeld is. Het is dus van groot belang om meer inzicht te krijgen in de verschillende organisatorische vormen van het leerlingwezen. Eerst zal in paragraaf 3.2 een overzicht worden gegeven van de verschillende leerlingstelsels. In paragraaf 3.3 wordt vervolgens gekeken naar de wijze waarop de praktijkcomponent in de verschillende leerlingstelsels is geregeld. Tot slot van dit hoofdstuk wordt ingegaan op de conjunctuurgevoeligheid van de instroom in het leerlingwezen. Dit hoofdstuk is hoofdzakelijk gebaseerd op gegevens uit de schoolverlatersenquête RUBS. Het gaat om informatie over leerlingen die het VBO, MBO of AVO in 1993 hebben verlaten en thans in het leerlingwezen zitten.

\subsection{De leerlingstelsels}

Het onderwijs in het leerlingwezen is georganiseerd per leerlingstelsel. Per stelsel is een landelijk orgaan verantwoordelijk voor de praktijkcomponent van de opleiding. De landelijke organen stellen in samenwerking met het bedrijfsleven en de scholen voor het Beroepsbegeleidend onderwijs (BBO) het onderwijsprogramma op. Bovendien verzorgen zij de examinering van de opleidingen. Er zijn momenteel 25 landelijke organen actief. De Landelijke Organisatie Beroepsopleidingen Agrarische Beroepen valt onder het ministerie van Landbouw, Visserij en Natuurbeheer. De overige landelijke organen vallen onder het ministerie van Onderwijs, Cultuur en Wetenschappen.

De meeste landelijke organen verzorgen opleidingen voor technische beroepen. Enkele grotere organen met relatief veel leerlingen op dat gebied zijn de Vereniging Elektrotechnisch Vakonderwijs (VEV), de Stichting Opleidingen Metaal (SOM), de Stichting Vakopleiding Bouwbedrijf (SVB) en het Innovatie- en onderwijscentrum auto- en tweewielerbranche (INNOVAM). De Stichting Hout \& Meubel (SH\&M) die opleidingen verzorgt voor onder andere meubelmaker en timmerman, het opleidingscentrum SVS voor het schilders- en stukadoorbedrijf en reclame- en presen- 
tatietechnieken en de Stichting Beroepsopleidingen Weg- en waterbouw (SBW) werken samen met het SVB in het Cluster Bouw- en Houtnijverheidsorganen. Andere organen die zich richten op de techniek zijn de Stichting Vakopleiding Schoen- en Lederwarenindustrie (VAS), de Stichting Vakopleiding Carrosseriebedrijf (VOC-car), Intechnium (installatietechniek), het instituut voor arbeidsmarkt en onderwijs voor de grafische en communicatie-industrie (GOC), de Stichting Vakopleiding Procesindustrie (VAPRO) en de Stichting Vakopleiding Gezondheidstechnische beroepen (SVGB).

De Stichting Opleidingen Brood en Banket (SOBB) leidt op tot brood en banketbakker. Dit orgaan is ontstaan uit een fusie van de Vereniging tot Bevordering van Opleidingen in de Banketbakkersbranche (VBOB) en de Stichting voor Vakopleiding en Examens in het Bakkersbedrijf (SVEB). De Stichting voor de Vleessector (SVO) verzorgt opleidingen voor onder andere slager.

Uit een fusie van de Stichting Vakopleiding Confectie Industrie (VOC-conf) en de Stichting Beroepsopleidingen Textielindustrie (BETEX) is recentelijk het Onderwijscentrum voor Textiel en Confectie (VOC/BETEX) ontstaan, dat opleidingen verzorgt voor onder andere textielspecialist, textieltechnoloog (BETEX) en kleermaker (VOC).

Er zijn drie organen die beroepsopleidingen verzorgen op het gebied van transport. De Stichting Koninklijk Onderwijsfonds voor de Scheepvaart (KOFS) verzorgt ondermeer opleidingen voor matroos en kapitein/schipper. De Stichting ter bevordering van het Leerlingwezen in het Haven en Vervoerbedrijf in Nederland (SLHV) leidt op tot operationele en administratieve medewerkers in haven en vervoersbedrijven, beveiligingscontroleurs, werktuigkundig monteurs en veiligheidsfunctionarissen. De Vakopleiding Wegvervoer (SWW/SLW) leidt niet alleen op voor chauffeur maar ook voor logistieke functies.

Het landelijke orgaan ECABO leidt op voor economische, administratieve en beveiligingsfuncties. Ook hier gaat het om een relatief groot orgaan. Het Opleidingsinstuut Voor de Distributie (OVD) verzorgt ondermeer opleidingen voor verkoopmedewerker en magazijnmedewerker voor de detailhandel en groothandel.

Het Onderwijscentrum Horeca $(\mathrm{OCH})$ verzorgt opleidingen voor kok, gastheer of gastvrouw, receptionist in hotel en verblijfsrecreatiebedrijven en horecaondernemer. Het onderwijscentrum zorg en welzijn (OVDB) leidt op tot bijvoorbeeld bejaardenverzorgende, kraamverzorgende en leider kindercentra. Tenslotte is er nog de stichting Vakopleiding Kappersbedrijf (SVK). Appendix A geeft een overzicht van de afkortingen van de diverse landelijke organen voor het leerlingwezen. 
Van een aantal organen zijn voor de meeste tabellen in dit hoofdstuk niet voldoende gegevens beschikbaar. Dat betreft VOC/BETEX, VAS, SH\&M, VAPRO, VOC-car, SBW, SVS, KOFS, SLHV en SVGB. Voor een deel komt dat omdat deze organen weinig leerlingen hebben. Het aantal waarnemingen in RUBS voor deze organen is dan te klein voor een representatief beeld. Ook zijn er organen die wel veel leerlingen hebben maar waar weinig schoolverlaters instromen. Dat geldt bijvoorbeeld voor VAPRO. Leerlingen die bij de VAPRO instromen hebben doorgaans al enkele jaren werkervaring en zijn gemiddeld ook ouder dan leerlingen van andere organen. De VAPRO is daarom ondervertegenwoordigd in RUBS.

Een leerlingstelsel is in principe op een bepaalde bedrijfssector gericht. Tabel 3.1 geeft de verdeling de werkgelegenheid van leerlingen per landelijk orgaan over de verschillende bedrijfstakken ${ }^{3}$. Het blijkt dat de bouwnijverheid een belangrijke sector is voor het leerlingwezen. Vijf landelijke organen verzorgen opleidingen die zich voornamelijk op de bouwnijverheid richten, namelijk Intechnium, VEV, SVS, SBW en SVB. Ook een gedeelte van de werkgelegenheid van leerlingen die aangesloten zijn bij het orgaan SH\&M concentreert zich in de bouwnijverheid. Kennelijk is het duale onderwijs met name in de bouw een belangrijk instrument om mensen op te leiden. Omdat de werkgelegenheid in de bouwnijverheid in de komende jaren naar verwachting zal toenemen, is alleen hierom al een groei van dit omvangrijke deel van het leerlingwezen te verwachten. Enkele andere voor het leerlingwezen belangrijke industriële bedrijfssectoren zijn de overige industrie (o.a. grafische industrie, papierindustrie, hout- en bouwmaterialenindustrie en textiel- en lederindustrie) en de metaal-elektro-industrie.

Tabel 3.1

Percentage leerlingen werkzaam in een bedrijfssector per orgaan 1992-1994: sectoren waarin minimaal $10 \%$ van de werkgelegenheid van de (primaire en voortgezette) leerlingen van een orgaan is geconcentreerd

\begin{tabular}{lc}
\hline & $\%$ \\
\hline LOBAS & \\
Landbouw en visserij & 54 \\
Handel & 39 \\
SOBB & \\
Handel & 66 \\
Voedings- en genotmiddelenindustrie & 30 \\
svo & \\
Handel & 92 \\
& \\
\hline
\end{tabular}

3. Het gaat hier om de Athena-bedrijfstakkenindeling zoals die door het Centraal Planbureau (CPB) wordt gehanteerd (zie ook ROA, 1995b). 
Tabel 3.1 (vervolg)

Percentage leerlingen werkzaam in een bedrijfssector per orgaan 1992-1994: sectoren waarin minimaal $10 \%$ van de werkgelegenheid van de (primaire en voortgezette) leerlingen van een orgaan is geconcentreerd

\section{VOC/BETEX}

Overige Industrie

Handel

VAS

SH\&M

Overige Industrie

Bouw

10

GOC

Overige Industrie

VAPRO

Chemie

Overige Industrie

Metaal en elektrotechniek

23

SOM

Metaal en elektrotechniek

VEV

Bouw

Metaal en elektrotechniek

VOC-CAR

Metaal en elektrotechniek

Overige commerciële dienstverlening

SVB

Bouw

SBW

Bouw

Intechnium

Bouw

SVS

Bouw

INNOVAM

Overige commerciële dienstverlening 80

Handel

10

SVWISLW

Transport, opslag en communicatie

Handel

Overige commerciële dienstverlening 
Tabel 3.1 (vervolg)

Percentage leerlingen werkzaam in een bedrijfssector per orgaan 1992-1994: sectoren waarin minimaal $10 \%$ van de werkgelegenheid van de (primaire en voortgezette) leerlingen van een orgaan is geconcentreerd

KOFS

Transport, opslag en communicatie

SLHV

Transport, opslag en communicatie

Handel

SVGB

Handel

Metaal en elektrotechniek

Kwartaire diensten

SVK

Overige commerciele dienstverlening

$\mathrm{OCH}$

Overige commerciele dienstverlening

OVD

Handel

ECABO

Bank- en verzekeringswezen

Overheid

Overige commerciele dienstverlening

Handel

OVDB

Kwartaire diensten

96

Bron: ROA (RUBS)

Opvallend is dat bij veel organen een deel van de werkgelegenheid zich - naast de specifieke sector waarop het orgaan is gericht - ook richt op de handel. Dat geldt bijvoorbeeld voor LOBAS, SOBB, VOC/BETEX, INNOVAM, SLW, SLHV, SVGB. Dat is niet zo verwonderlijk omdat veel organen ook opleidingen verzorgen voor beginnend of zelfstandig beroepsbeoefenaar in de detailhandel bijvoorbeeld voor verkoper in een bloemenzaak of bloemist (LOBAS) of opticien (SVGB). De overige commerciële dienstverlening, een sector waar de werkgelegenheid de komende jaren sterk zal groeien, is van belang voor onder andere VOC-car, Innovam, SLW, SVK, SVH en ECABO. ECABO leidt op voor economisch-administratieve functies. De werkgelegenheid van leerlingen bij ECABO is daardoor niet op één specifieke bedrijfssector gericht maar is verspreid over verschillende sectoren. Dat geldt in iets mindere mate ook voor de werkgelegenheid van leerlingen bij de VAPRO. De VAPRO verzorgt opleidingen voor de procesindustrie. In diverse bedrijfstakken, 
waaronder de chemische industrie, de metaalindustrie en de papierindustrie wordt gebruik gemaakt van procestechniek.

Tabel 3.2

Percentage leerlingen werkzaam in een beroepsklasse per landelijk orgaan 1992-1994: beroepsklassen waarin minstens $10 \%$ van de (primaire en voortgezette) leerlingen van een orgaan werkzaam is

\section{$\%$}

\section{LOBAS}

Uitvoerend agrarisch personeel 62

Fotografen, ontwerpers en vormgevers $\quad 20$

$\begin{array}{ll}\text { Verkooppersoneel } & 12\end{array}$

SOBB

$\begin{array}{ll}\text { Bakkers en chocolademakers } & 97\end{array}$

SVO

Voedings- en genotmiddelenbereiders $\quad 65$

Verkooppersoneel 32

VOC-C/BETEX

$\begin{array}{ll}\text { Patroonmakers, naaiers en zeilmakers } & 90\end{array}$

VAS

\section{SH\&M}

Timmerlieden

Stoffeerders en ledenwarenmakers

GOC

Produktiepersoneel grafische industrie

VAPRO

Produktiepersoneel chemische industrie

\section{SOM}

Lassers, constructeurs en edelsmeden $\quad 34$

Machinebank-, plaatwerkers en smeden

VEV

Monteurs en controleurs elektrotechnische installaties

\section{VOC-CAR}

Machinebank-, plaatwerkers en smeden

53

Produktiepersoneel aardewerk-, en glasindustrie

28

Automonteurs en herstellers

SVB

Timmerlieden 
Tabel 3.2 (vervolg)

Percentage leerlingen werkzaam in een beroepsklasse per orgaan 1992-1994: beroepsklassen waarin minstens $10 \%$ van de (primaire en voortgezette) leerlingen van een orgaan werkzaam is

\section{$\%$}

SBW

Machinisten bouw en industrie

Wegenbouwvakkrachten en buizenleggers $\quad 26$

Metselaars en stukadoors

Intechnium

Loodgieters en installateurs

Monteurs en controleurs elektrotechnische installaties

SVS

Schilders

Metselaars en stukadoors

INNOVAM

Automonteurs en herstellers

SVWISLW

Chauffeurs en spoorwegpersoneel 48

Expeditie-medewerkers

Automonteurs en herstellers

KOF

Scheepsdek- en machinekamerpersoneel

SLHV

Commercieel-administratieve employées

Expeditie-medewerkers

Secretaresses en typisten

SVGB

Opticiens en apothekersassistenten

SVK

Kappers en schoonheidsspecialisten

$\mathrm{OCH}$

Keuken- en serveerpersoneel

OVD

Administrateurs en bankemployées

\section{ECABO}

Secretaresses en typisten 
Tabel 3.2 (vervolg)

Percentage leerlingen werkzaam in een beroepsklasse per orgaan 1992-1994: beroepsklassen waarin minstens $10 \%$ van de (primaire en voortgezette) leerlingen van een orgaan werkzaam is

\begin{tabular}{ll}
\hline & $\%$ \\
\hline $\begin{array}{l}\text { OVDB } \\
\text { Kinder-, gezins- en bejaardenverzorgenden } \\
\text { Leerling-verpleegkundigen, zieken- en kraamverzorgenden* }\end{array}$ & 77 \\
\hline * In de ROA-beroepsklasse indeling zijn de leerlingverpleegkundigen ingedeeld bij de zieken- \\
en kraamverzorgenden. De OVDB leidt echter alleen op tot verzorgenden en niet tot \\
verpleegkundigen.
\end{tabular}

Tabel 3.2 geeft een overzicht van de belangrijkste beroepsklassen ${ }^{4}$ waarvoor leerlingen worden opgeleid per landelijk orgaan. Het blijkt dat enkele landelijke organen mensen niet alleen voor specifieke vaktechnische beroepen opleiden maar ook voor meer algemene beroepen, zoals winkelbedienden en commercieel administratieve employées. Dat geldt bijvoorbeeld voor LOBAS (verkoper in een bloemenzaak), SVO (verkoopmedewerker in slagerij) en SLHV (technisch administratief medewerker). Kennelijk is het voor het uitoefenen van dergelijke functies in sommige branches belangrijk om specifieke kennis over de branche of over het produkt te bezitten. Het leerlingwezen is dus niet alleen van belang voor het aanleren van specifieke vaktechnische vaardigheden maar ook voor het aanleren van specifieke kennis over de branche waarin men werkzaam is.

Tabel 3.3 geeft de de vooropleiding van personen die een primaire opleiding in het leerlingwezen volgen. Deze gegevens zijn gebaseerd op RUBS. Dat betekent dat het alleen schoolverlaters van de dagopleidingen $\mathrm{VBO}, \mathrm{MBO}$ en AVO en BBOopleidingen betreft. Voortijdig schoolverlaters, mensen die eerder een oriëntatie- en schakelopleiding hebben gevolgd en mensen die zich al langer op de arbeidsmarkt bevinden voor ze een leerlingwezenopleiding zijn gaan volgen niet zijn meegenomen. Bovendien is de steekproef van BBO-schoolverlaters niet dekkend naar richting. Het percentage van de instroom dat al een leerlingwezenopleiding heeft gevolgd kan dus vertekend zijn. Het blijkt dat $80 \%$ van de instroom een vooropleiding op VBO/MAVO-niveau heeft, $15 \%$ op KMBO of primair leerlingwezen-niveau en $5 \%$ op MBO-niveau. Het percentage met een vooropleiding op MBO-niveau is relatief hoog bij het ECABO, GOC, LOBAS en OVDB. Bij SOBB, SOM, SVB, Intechnium, INNOVAM, SVK en OVD is het percentage met een vooropleiding op MBO-niveau beduidend lager dan gemiddeld.

4. Het gaat hier om de ROA-beroepsklasse-indeling (zie ook ROA, 1995b). 
Tabel 3.3

Instroom primair LLW naar niveau van de vooropleiding (op basis van RUBS), 1994

\begin{tabular}{|c|c|c|c|}
\hline & $\begin{array}{l}\text { VBO" } \\
\%\end{array}$ & $\begin{array}{l}\mathrm{KMBO}^{2)} \\
\%\end{array}$ & $\begin{array}{l}\mathrm{MBO}_{\%}^{3)} \\
\%\end{array}$ \\
\hline LOBAS & 75 & 15 & 10 \\
\hline SOBB & 90 & 10 & 0 \\
\hline SVO & 90 & 5 & 5 \\
\hline VOC-C/BETEX & - & - & - \\
\hline VAS & - & - & - \\
\hline SH\&M & - & - & - \\
\hline GOC & 90 & 0 & 10 \\
\hline VAPRO & - & - & - \\
\hline SOM & 85 & 15 & 0 \\
\hline VEV & 65 & 30 & 5 \\
\hline VOC-CAR & & - & - \\
\hline SVB & 95 & 5 & 0 \\
\hline SBW & - & - & - \\
\hline Intechnium & 75 & 25 & 0 \\
\hline SVS & - & - & - \\
\hline INNOVAM & 90 & 10 & 0 \\
\hline SWW/SLW & 90 & 5 & 5 \\
\hline KOF & - & - & - \\
\hline SLHV & - & - & - \\
\hline SVGB & - & - & - \\
\hline SVK & 75 & 25 & 0 \\
\hline $\mathrm{OCH}$ & 85 & 15 & 5 \\
\hline OVD & 70 & 30 & 0 \\
\hline ECABO & 55 & 25 & 20 \\
\hline OVDB & 50 & 40 & 10 \\
\hline Totaal & 80 & 15 & 5 \\
\hline
\end{tabular}

1) inclusief MAVO

${ }^{2)}$ inclusief primair leerlingwezen

3) inclusief HAVO, WWO en voortgezet leerlingwezen

Bron: ROA (RUBS)

\subsection{De praktijkcomponent}

Een belangrijke voorwaarde voor een verdere groei van het leerlingstelsel is een voldoende aanbod van leer-arbeidsplaatsen. In hoofdstuk 2 werd ingegaan op het belang van de positie die leerlingen in het bedrijf hebben, voor hun latere arbeidsmarktperspectief. Het is daarom belangrijk om een goed zicht te hebben in de verschillende vormen van praktijkonderwijs in de verschillende leerlingstelsels. In principe wordt bij de start van de opleiding een leerovereenkomst (LOK) afgesioten met de leerling, het landelijke orgaan en het leerbedrijf (de patroon). Doorgaans wordt ook een arbeidsovereenkomst met de leerling afgesloten. De leerling ontvangt dan loon. In sommige sectoren is dit per CAO geregeld. In andere sectoren kunnen bedrijven dit zelf bepalen. Als leerlingen alleen een LOK hebben dan ontvangen zij geen loon maar kunnen zij wel een onkostenvergoeding krijgen. Ook voor de 
vergoeding geldt dat deze in sommige sectoren in de CAO is vastgelegd en in andere sectoren bedrijven zelf de hoogte van de vergoeding kunnen bepalen. Het kan dus voorkomen dat een leerling geen onkostenvergoeding ontvangt. Verder bestaan er in sommige sectoren GOA's (Centra gemeenschappelijke opleidingsactiviteiten). Een GOA kan dienen om de opleidingsdoelstellingen per bedrijfstak te coördineren. Hierdoor wordt free-riders-gedrag bestreden. Het komt echter ook voor dat men alleen stage loopt in het kader van het leerlingwezen. De wijze waarop de praktijkcomponent in een sector geregeld is geeft aan hoe belangrijk men het leerlingwezen in die sector vindt als opleidingsinstrument voor vakkrachten. Als het bedrijfsleven veel belang heeft bij het leerlingwezen omdat het een belangrijke bron van nieuwe vakkrachten is, zal men meer moeite doen om de praktijkcomponent goed te regelen. Als men weinig belang hecht aan de opleidingscomponent van het leerlingwezen, maar leerlingen slechts als goedkope arbeidskrachten beschouwt, dan valt te verwachten dat de praktijkcomponent veel minder goed geregeld is.

Tabel 3.4

Plannen van schoolverlaters AVO, VBO, (K)MBO en BBO bij het verlaten van de opleiding naar huidige bezigheid, 1994

\begin{tabular}{lcccc}
\hline & alleen werken & $\begin{array}{c}\text { alleen verder } \\
\text { leren } \\
\%\end{array}$ & $\begin{array}{c}\text { werken en } \\
\text { leren } \\
\%\end{array}$ & $\begin{array}{c}\text { iets anders } \\
\%\end{array}$ \\
\hline Huidige bezigheid & & & & \\
Scholier & 1 & 92 & 7 & 14 \\
Betaald werk & 80 & 4 & 28 & 33 \\
LLW/in-service & 2 & 2 & 55 & 3 \\
Werkloos & 8 & 2 & 5 & 14 \\
Onbetald werk & 1 & 0 & 0 & 1 \\
Huishouden & 1 & 0 & 0 & 2 \\
Milit/vervangende dienst & 7 & 1 & 5 & 29 \\
Anders & 0 & 0 & 0 & 3 \\
\hline
\end{tabular}

Bron: ROA (RUBS)

Voordat wordt ingegaan op de positie die een leerling binnen het leerlingwezen bekleedt, dient eerst ingegaan te worden op de vraag in hoeverre schoolverlaters die niet voltijd verder willen studeren, maar werken met leren willen combineren, ook in staat zijn een dergelijke leer-arbeidsplaats te bemachtigen. Tabel 3.4 geeft de relatie tussen de toekomstplannen die leerlingen hadden voordat zij hun (voor)opleiding verlieten en hun huidige bezigheid. Vrijwel iedereen die thans een leerlingwezenopleiding volgt wilde dit ook doen. Opmerkelijk is echter dat slechts $55 \%$ van degenen die werken met leren wilde combineren ook op het moment van enquête een dergelijke positie hebben verworven. De andere plannen - vooral alleen verder leren - zijn in veel grotere mate verwezenlijkt. Van degenen die geen 
leerlingplaats konden bemachtigen heeft een groot deel thans betaald werk. Dat duidt erop dat deze groep veel meer op werken dan op leren is gericht en het (K)MBO dus geen goed alternatief voor hen vormt.

Tabel 3.5

Percentage van de (primaire) leerlingen per orgaan dat naast het theorie gedeelte ook nog werk of een stage plaats heeft in het kader van het leerlingwezen, 1994

\begin{tabular}{|c|c|c|c|c|}
\hline & $\begin{array}{c}\text { betaald werk } \\
\%\end{array}$ & $\begin{array}{c}\text { onkostenvergoeding } \\
\%\end{array}$ & $\begin{array}{c}\text { onbetaald werk } \\
\%\end{array}$ & $\begin{array}{c}\text { alleen theorie } \\
\%\end{array}$ \\
\hline LOBAS & 95 & 5 & 0 & 5 \\
\hline SOBB & 95 & 0 & 0 & 5 \\
\hline SVO & 95 & 5 & 0 & 0 \\
\hline VOC-C/BETEX & - & - & - & - \\
\hline VAS & - & - & - & - \\
\hline SH\&M & - & - & - & - \\
\hline GOC & 100 & 0 & 0 & 0 \\
\hline VAPRO & - & - & - & - \\
\hline SOM & 50 & 30 & 0 & 20 \\
\hline VEV & 55 & 15 & 5 & 25 \\
\hline VOC-CAR & - & - & - & - \\
\hline SVB & 85 & 0 & 0 & 10 \\
\hline SBW & - & - & - & - \\
\hline Intechnium & 90 & 5 & 0 & 5 \\
\hline SVS & - & - & - & - \\
\hline INNOVAM & 75 & 15 & 0 & 10 \\
\hline SWWISLW & 95 & 5 & 0 & 0 \\
\hline KOF & - & - & - & - \\
\hline SLHV & - & - & - & - \\
\hline SVGB & - & - & - & - \\
\hline SVK & 95 & 0 & 0 & 5 \\
\hline $\mathrm{OCH}$ & 95 & 5 & 0 & 0 \\
\hline OVD & 90 & 5 & 0 & 5 \\
\hline ECABO & 25 & 45 & 20 & 10 \\
\hline OVDB & 40 & 20 & 35 & 5 \\
\hline Totaal & 75 & 10 & 5 & 10 \\
\hline
\end{tabular}

Bron: ROA (RUBS)

Een belangrijke aanwijzing voor het belang van het leerlingwezen voor een bepaalde sector is het percentage leerlingen dat betaald werk heeft in het kader van het leerlingwezen, dat zijn in principe de leerlingen die naast een leerovereenkomst ook nog een arbeidsovereenkomst hebben. Het percentage van de leerlingen dat betaald werk heeft verschilt sterk per landelijk orgaan, zoals blijkt uit tabel 3.5. Zo hebben leerlingen van het $G O C$ altijd betaald werk, en ook leerlingen van de LOBAS, SOBB, SVO, SLW, OCH en OVD hebben bijna altijd betaald werk. Bij veel van deze organen is het hebben van werk ook een ingangseis voor de opleiding. Als een leerling binnen een bepaalde termijn na de aanvang van de opleiding geen werk heeft gevonden dat mag hij de opleiding niet afmaken. Zo geldt bijvoorbeeld voor leerlingen van de SVK dat men voor 31 december van het jaar waarin men de 
opleiding is begonnen een baan moet hebben gevonden. Bovendien geldt voor leerlingen van de SVK dat er naast een leerovereenkomst ook altijd een arbeidsovereenkomst moet worden afgesloten.

Bij de SWW/SLW sluiten de leerlingen een arbeidsovereenkomst met de SWW. Deze stichting fungeert als collectieve werkgever. De leerling wordt vervolgens door de SWW bij leerbedrijven geplaatst en de leerbedrijven wordt het loon van de leerlingen in rekening gebracht. In principe zijn leerlingen van de SWWISLW dus verzekerd van een leerplaats.

Bij de SOM en de VEV heeft slechts ongeveer de helft van de leerlingen betaald werk. Veel leerlingen krijgen alleen een onkostenvergoeding. Het is mogelijk dat deze leerlingen de praktijkcomponent bij de Centra Vakopleiding volgen. Onbetaald werk komt bij SOM en VEV weinig voor. Wel is het aandeel van leerlingen die alleen het theoriegedeelte volgen vrij hoog. Bij de VEV mag een leerling in principe wel doorgaan met de theorieopleiding als hij nog geen werk heeft gevonden. Bij de VEV werkt men overigens veel met GOA-constructies. Leerlingen krijgen dan twee dagen praktijkonderwijs op een regionaal opleidingscentrum, een samenwerkingsverband van bedrijven uit de sector. Verder werken ze nog twee dagen in de week bij een van de aangesloten bedrijven. Ze hebben wel een arbeidsovereenkomst. Als er geen plaatsen in de opleidingscentra zijn dan moeten leerlingen zelf een praktijkplaats vinden. Ook bij de SVB zijn GOA-constructies erg belangrijk. Ongeveer $80 \%$ van de leerlingen van de SVB heeft een arbeidovereenkomst met een samenwerkingsverband van bouwbedrijven. Ze worden daar geplaatst via opleidingsconsulenten van de SVB.

Bij ECABO en OVDB is het percentage dat betaald werk heeft erg laag. Bovendien zijn dit de enige organen waarbij een flink deel van de leerlingen onbetaald werk verricht. Bij ECABO mogen leerlingen die nog geen praktijkplaats hebben gevonden toch doorgaan met de opleiding, ze worden dan zoveel mogelijk geholpen om alsnog een praktijkplaats te vinden.

Tabel 3.6 geeft het percentage van de leerlingen met betaald werk in het kader van het leerlingwezen, dat vast werk heeft. Het is mogelijk dat een bedrijf iemand in vaste dienst neemt met als voorwaarde dat hij een opleiding volgt. In dat geval voorziet het bedrijf in de eigen behoefte aan geschoold personeel door zelf mensen op te leiden. Het blijkt dat ruim de helft van de leerlingen met betaald werk in het kader van het leerlingwezen ook een vaste baan heeft. Uit de tabel wordt duidelijk dat vooral bij OVD en INNOVAM het percentage van de leerlingen met vast werk erg hoog is. Opvallend zijn ook de hoge percentages voor de SOM en de VEV. Terwijl het percentage met betaald werk voor deze organen lager dan gemiddeld is, is het percentage met vast werk juist hoger dan gemiddeld. $\mathrm{Bij}$ de $\mathrm{OCH}$ heeft 
slechts een enkele leerling vast werk. De horeca is bij uitstek een sector waar men behoefte heeft aan goedkope (makkelijk inzetbare) krachten omdat er vaak sprake is van piekbelasting.

Tabel 3.6

Percentage van de (primaire) leerlingen per orgaan dat vast werk heeft, 1994

$\%$

\begin{tabular}{lc} 
LOBAS & 40 \\
SOBB & - \\
SVO & - \\
VOC-C/BETEX & - \\
VAS & - \\
SH\&M & - \\
GOC & - \\
VAPRO & - \\
SOM & 60 \\
VEV & 60 \\
VOC-CAR & - \\
SVB & 40 \\
SBW & - \\
Intechnium & 65 \\
SVS & - \\
INNOVAM & - \\
SLW & 80 \\
KOF & 15 \\
SLHV & - \\
SVGB & - \\
SVK & - \\
OCH & 65 \\
OVD & 0 \\
ECABO & 75 \\
OVDB & - \\
Totaal & - \\
\hline
\end{tabular}

Bron: ROA (RUBS)

Uit tabel 3.7 blijkt dat de werkgelegenheid voor leerlingen geconcentreerd is bij bedrijven met minder dan 50 werknemers. Dit is voor een deel te verklaren door de aard van bedrijfstak waar de opleiding zich op richt. Reparatiebedrijven, landbouwbedrijven (LOBAS) en kapperszaken (SVK) bijvoorbeeld hebben over het algemeen minder dan 50 werknemers. Alleen leerlingen van de VEV, Intechnium en OVD werken relatief vaak in grote bedrijven met meer dan 500 werknemers.

Verschillen in het gemiddelde bruto loon en in de variantie van het loon tussen organen kunnen mogelijk verklaard worden uit de mate waarin in bepaalde sectoren lonen voor leerlingen in de CAO zijn vastgelegd. Tabel 3.8 geeft een overzicht van de gemiddelde lonen per orgaan met hun standaardafwijking. Ook de mate waarin door bedrijven in een bedrijfstak wordt samengewerkt op het gebied van de 
opleidingen is van belang. Als de organisatiegraad in een branche met betrekking tot de opleidingen hoog is, zal de variantie in de lonen laag zijn. Het gaat hier om personen met betaald werk, dus de onkostenvergoedingen zijn buiten beschouwing gelaten. Bij de SLW is de variantie in het bruto uurloon erg laag maar het loon is lager dan gemiddeld. Dit is te verklaren door de afwijkende organisatie van de opleidingen in dit stelsel. Het gemiddelde loon voor leerlingen bij de VEV en de SVB is vrij hoog. De variantie in het loon van leerlingen van de VEV en de SVB is ondanks de hoge organisatiegraad van de bedrijfstak eveneens hoog. Leerlingen van de SVK verdienen gemiddeld minder dan leerlingen van andere organen. De Ionen voor leerlingkappers zijn vastgelegd in het $\mathrm{CAO}$, daarom is de variantie in lonen vrij gering.

Tabel 3.7

Omvang van het bedrijf waar de leerling werkt in het kader van het leerlingwezen, per orgaan (primaire opleidingen), 1994

\begin{tabular}{|c|c|c|c|c|c|c|}
\hline \multicolumn{7}{|c|}{ Aantal werknemers } \\
\hline & $\begin{array}{c}<10 \\
\%\end{array}$ & $\begin{array}{c}10-49 \\
\%\end{array}$ & $\begin{array}{c}50-99 \\
\%\end{array}$ & $\begin{array}{c}100-499 \\
\%\end{array}$ & $\begin{array}{c}500-999 \\
\%\end{array}$ & $\begin{array}{c}>=1000 \\
\%\end{array}$ \\
\hline LOBAS & 65 & 30 & 5 & 0 & 0 & 5 \\
\hline SOBB & - & - & - & - & - & - \\
\hline SVO & - & - & - & - & - & - \\
\hline VOC-C/BETEX & - & - & - & - & - & - \\
\hline VAS & - & - & - & - & - & - \\
\hline SH\&M & - & - & - & - & - & - \\
\hline GOC & - & - & - & - & - & - \\
\hline VAPRO & - & - & - & - & - & - \\
\hline SOM & 10 & 45 & 10 & 20 & 5 & 10 \\
\hline VEV & 25 & 25 & 15 & 5 & 10 & 25 \\
\hline VOC-CAR & - & - & - & - & - & - \\
\hline SVB & 10 & 50 & 10 & 20 & 5 & 0 \\
\hline SBW & - & - & - & - & - & - \\
\hline Intechnium & 25 & 10 & 15 & 15 & 15 & 20 \\
\hline SVS & - & - & - & - & - & - \\
\hline INNOVAM & 65 & 15 & 5 & 10 & 5 & 5 \\
\hline SLW & 10 & 30 & 25 & 25 & 0 & 10 \\
\hline KOF & - & - & - & - & - & - \\
\hline SLHV & - & - & - & - & - & - \\
\hline SVGB & - & - & - & - & - & - \\
\hline SVK & 70 & 25 & 5 & 0 & 0 & 0 \\
\hline $\mathrm{OCH}$ & 30 & 45 & 15 & 5 & 5 & 0 \\
\hline OVD & 25 & 25 & 10 & 10 & 15 & 25 \\
\hline ECABO & - & - & - & - & - & - \\
\hline OVDB & - & - & - & - & - & - \\
\hline Totaal & 40 & 30 & 10 & 10 & 5 & 10 \\
\hline
\end{tabular}

Bron: ROA (RUBS) 
Tabel 3.8

Gemiddeld bruto uurloon van (primaire) leerlingen met betaald werk, 1994

\begin{tabular}{|c|c|c|c|}
\hline Orgaan & $\begin{array}{l}\text { Gemiddeld loon } \\
\text { in guldens }\end{array}$ & standaardafwijking & $n$ \\
\hline LOBAS & 8,30 & 2,4 & 17 \\
\hline SOBB & 9,70 & 5,2 & 10 \\
\hline SVO & 8,70 & 3,0 & 11 \\
\hline VOC/BETEX & - & - & - \\
\hline VAS & - & - & - \\
\hline SH\&M & - & - & - \\
\hline GOC & 12,20 & 4,0 & 12 \\
\hline VAPRO & - & - & - \\
\hline SOM & 9,00 & 4,7 & 21 \\
\hline VEV & 10,30 & 5,3 & 21 \\
\hline VOC-CAR & - & - & - \\
\hline SVB & 9,40 & 3,6 & 28 \\
\hline SBW & - & - & - \\
\hline Intechnium & 8,70 & 3,3 & 14 \\
\hline SVS & - & - & - \\
\hline INNOVAM & 8,20 & 3,8 & 16 \\
\hline SLW & 7,50 & 1,3 & 17 \\
\hline KOF & - & - & - \\
\hline SLHV & - & - & - \\
\hline SVGB & - & - & - \\
\hline SVK & 6,60 & 2,2 & 53 \\
\hline $\mathrm{OCH}$ & 9,00 & 2,5 & 43 \\
\hline OVD & 7,80 & 4,1 & 47 \\
\hline ECABO & - & - & - \\
\hline OVDB & - & - & - \\
\hline Totaal & 8,70 & 4,1 & 363 \\
\hline
\end{tabular}

Bron: ROA (RUBS)

Tabel 3.9 geeft de geschatte coëfficiënten van een loonvergelijking voor leerlingen met betaald werk. Het loon is in deze vergelijking afhankelijk van de leeftijd, het geslacht, de omvang van het bedrijf waarin men werkzaam is, de vooropleiding, de bedrijfsector, het aantal gewerkte uren en het hebben van vast werk. De te verklaren variabele is het logaritme van het bruto uurloon. Een leerling met vast werk blijft ook na het voltooien van de opleiding bij het bedrijf in dienst. Het bedrijf zal in dat geval ook zelf profijt hebben van het opleiden van leerlingen. Het valt te verwachten dat het bedrijf daarom meer bereid zal zijn om de kosten van de opleiding te dragen. Het feit dat iemand vast werk heeft blijkt echter geen significante invloed te hebben op de hoogte van het loon. De vooropleiding is wel van belang: leerlingen met een vooropleiding op MBO- of KMBO-niveau verdienen meer dan leerlingen met een vooropleiding op VBO-niveau. Vrouwen verdienen ook wanneer gecorrigeerd wordt voor de specifieke bedrijfssector gemiddeld minder dan mannen. 
Tabel 3.9

Loonvergelijking voor (primaire) leerlingen in het LLW, 1994

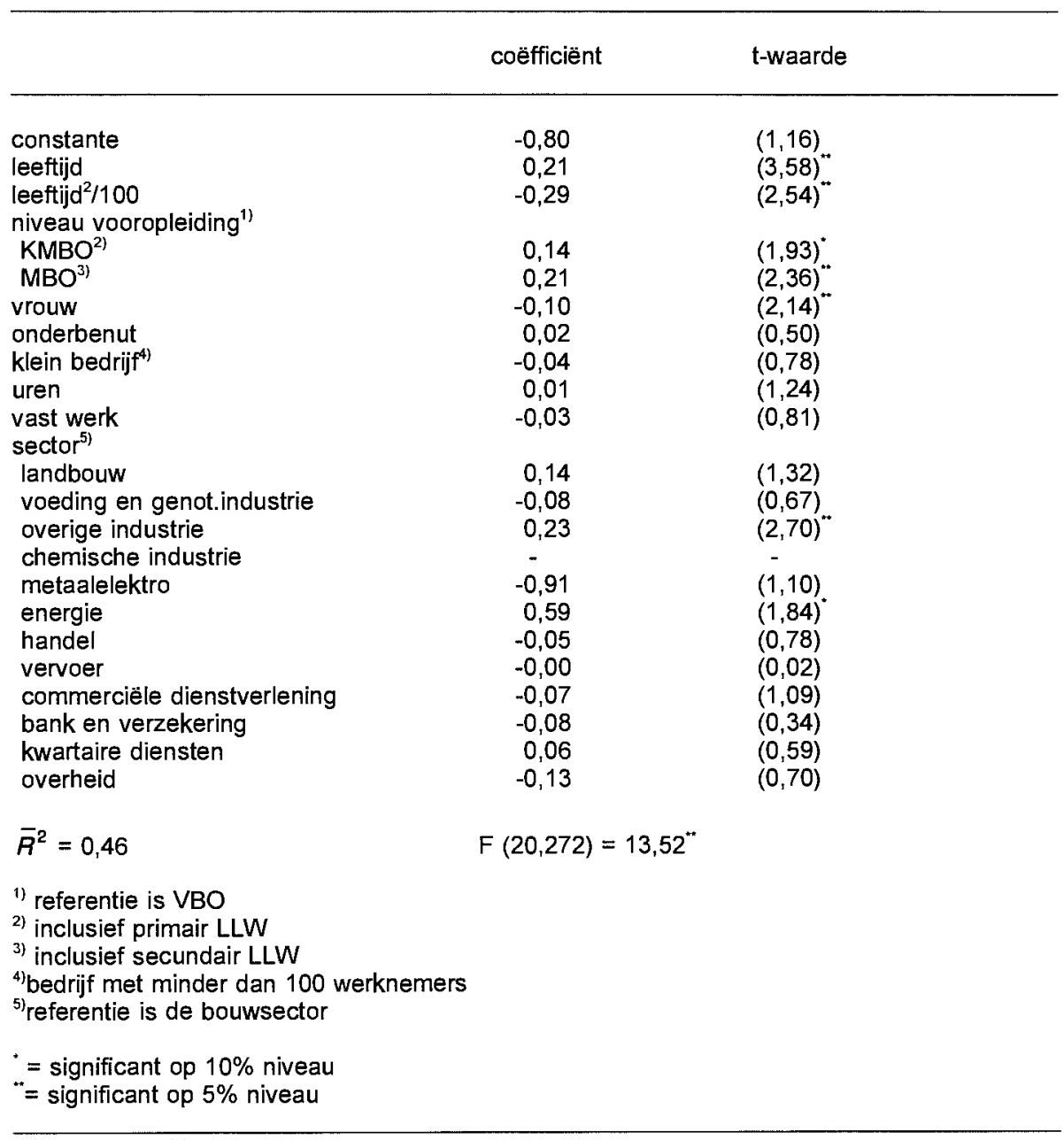

Bron: ROA (RUBS)

Het minimaal aantal uren dat een leerling per week moet werken verschilt nogal per stelsel. Bij veel opleidingen van de OVDB is het minimaal aantal uren voor de primaire opleidingen 16 uur per week. Bij de OCH, OVD, SVS, SOBB en LOBAS is dat meestal minimaal 20 uur. Bij INNOVAM, SBW, GOC, SH\&M, SVO en SVB is dat minimaal 32 uur per week. De praktijkcomponent is dus niet bij alle opleidingen even zwaar. Tabel 3.10 geeft het gemiddeld aantal uren per week voor leerlingen met betaald werk. Het blijkt dat er in de praktijk gemiddeld weinig verschillen zijn in 
aantallen uren tussen stelsels ${ }^{5}$. Gemiddeld werkt een leerling 30 uur per week. Alleen bij de SVO, GOC, VEV, SVB, SBW, SVS, SLW, SVGB en OCH werken leerlingen gemiddeld significant meer dan 30 uur per week. Bij OVD en SVK werkt men minder dan 30 uur per week. Bij de SVWISLW werken alle leerlingen 32 uur per week.

Tabe/ 3.10

Gemiddeld aantal uren per week dat (primaire) leerlingen betaald werk verrichten, 1994

\begin{tabular}{lcc}
\hline & $\begin{array}{l}\text { Gemiddeld aantal } \\
\text { uren }\end{array}$ & standaardafwijking \\
\hline LOBAS & 30,9 & \\
SOBB & 30,7 & 3,2 \\
SVO & 31,4 & 2,9 \\
VOC/BETEX & - & 1,2 \\
VAS & - & - \\
SH\&M & - & - \\
GOC & 31,0 & - \\
VAPRO & - & 1,7 \\
SOM & 29,5 & - \\
VEV & 31,3 & 4,5 \\
VOC-CAR & - & 2,4 \\
SVB & 32,3 & - \\
SBW & - & 1,5 \\
Intechnium & 30,9 & - \\
SVS & 30,7 & 3,9 \\
INNOVAM & 30,6 & 1,0 \\
SLW & 32,0 & 3,6 \\
KOFS & - & 0,0 \\
SLHV & - & - \\
SVGB & - & - \\
SVK & 28,4 & - \\
OCH & 31,8 & 4,4 \\
OVD & 27,6 & 4,3 \\
ECABO & 31,2 & 5,8 \\
OVDB & - & 2,5 \\
Totaal & 30,1 & - \\
& & 4,3 \\
\hline BIOn: ROA (RUBS) &
\end{tabular}

Bron: ROA (RUBS)

\subsection{Conjunctuurgevoeligheid van de instroom}

Omdat voor het leerlingwezen reeds tijdens de opleiding de band met de arbeidsmarkt bestaat, geldt dat naast de mogelijke arbeidsmarktrisico's voor de gediplo-

5. Alleen leerlingen die betaald werk verrichten zijn in beschouwing genomen. Mogelijk zijn de verschillen in aantal werkzame uren groter als ook leerlingen met onbetaald werk in beschouwing zouden zijn genomen. Voor deze groep zijn echter geen gegevens beschikbaar over werkzame uren. 
meerden als gevolg van conjuncturele fluctuaties, ook de instroommogelijkheden in de leer-arbeidsplaatsen in meer of mindere mate afhankelijk zijn van schommelingen op de arbeidsmarkt. Voor het aangaan van een leerarbeidsovereenkomst is men immers afhankelijk van de leer-arbeidsplaatsen die door de werkgevers worden aangeboden. Als werkgevers zich bij het beschikbaarstellen van leer-arbeidsplaatsen sterk laten leiden door de economische situatie van het moment, kunnen er conjuncturele schommelingen in de instroommogelijkheden ontstaan. Dit betekent dat de actuele economische situatie mede bepalend wordt voor het aantal gekwalificeerde vakarbeiders dat twee of drie jaar later het leerlingwezen verlaat. Dit bergt het gevaar in zich dat er tijdens een recessie te weinig leerlingen worden opgeleid, waardoor er bij een economische opleving een tekort ontstaat. Een adequaat opleidingsbeleid zou derhalve minder conjunctuurgevoelig moeten zijn door in plaats van op de actuele situatie in de bedrijfstak, de instroom in het leerlingwezen af te stemmen op de werkgelegenheidsontwikkeling op de middellange termijn. Te verwachten valt dat voor bedrijven en bedrijfstakken waar het leerlingwezen in belangrijke mate voorziet in de vraag naar gekwalificeerd vakpersoneel, dergelijke voorzorgsmaatregelen beter geregeld zijn dan elders.

Tabel 3.11 geeft voor een aantal landelijke organen van het leerlingwezen een indicatie van de conjunctuurgevoeligheid van de instroom ${ }^{6}$. Deze indicator geeft aan in welke mate de instroom in het leerlingwezen fluctueert als gevolg van schommelingen in de werkgelegenheid van bedrijfssectoren ${ }^{7}$. Het blijkt dat er een opmerkelijke discrepantie bestaat tussen de conjunctuurgevoeligheid van de instroom in het leerlingwezen en de conjunctuurgevoeligheid van de werkgelegenheidsontwikkeling van de desbetreffende opleidingstypen. Zo blijken bij de technische opleidingen diverse landelijke organen een (erg) lage of gemiddelde conjunctuurgevoeligheid van de instroom te vertonen. Dat geldt bijvoorbeeld voor organen in de richting bouwkunde, (SH\&M, SVB en SVS). De conjunctuurgevoeligheid van de werkgelegenheid voor het opleidingstype MBO/LLW bouwkunde is daarentegen erg hoog. Ook voor de SOM en de VEV is de conjunctuurgevoeligheid van de instroom respectievelijk erg laag en laag terwijl de conjunctuurgevoeligheid van de werkgelegenheid voor de overeenkomende opleidingstypes juist hoog is. Alleen bij de INNOVAM, VOC, BETEX en de VAPRO is de conjunctuurgevoeligheid van de leerlingeninstroom hoog of erg hoog. Bij de VAPRO blijkt een groot deel van de leerlingen overigens niet direct vanuit het dagonderwijs het leerlingwezen in te stromen, maar betreft het vooral personen die reeds werkzaam zijn in de procestechniek en vanuit die positie een opleiding in het leerlingwezen gaan volgen. In de

6. De opleidingsindeling die hier wordt gepresenteerd is de opleidingsindeling zoals die wordt gehanteerd in ROA, 1995 a,b (zie ook hoofdstuk 6).

7. Zie ook ROA, 1995c. 
overige technische richtingen weet men kennelijk een redelijke constante instroom van leerlingen te realiseren, zonder dat hierbij de conjuncturele situatie een doorslaggevende rol speelt. Bij de niet technische richtingen is de conjunctuurgevoeligheid van de leerlingeninstroom soms groter. Bij de ECABO opleidingen is de conjunctuurgevoeligheid zelfs hoog. Dat is vooral opmerkelijk omdat de werkgelegenheid van de opleidingstypen MBO/LLW administratief en MBO/LLW secretarieel gemiddeld tot laag is. Buiten de OVDB, die een lage conjunctuurgevoeligheid van de instroom kent, scoren alle overige niet-technische opleidingstypen gemiddeld op deze indicator. Zeker gezien de grote conjunctuurgevoeligheid van de omgeving waarin zij opereren, lijken de meeste technische opleidingsrichtingen toch beter in staat een constante leerlingeninstroom te realiseren.

Tabel 3.11

Conjunctuurgevoeligheid van de instroom in het leerlingwezen

\begin{tabular}{|c|c|c|}
\hline Opleidingstype/orgaan & conjunctuurgevoeligheid & typering \\
\hline $\begin{array}{l}\text { MBO/LLW bouwkunde } \\
\text { houtbedrijf, SH\&M } \\
\text { bouw, SVB } \\
\text { schilders/stukadoors, SVS }\end{array}$ & $\begin{array}{l}0,13 \\
0,09 \\
0,14\end{array}$ & $\begin{array}{l}\text { laag } \\
\text { erg laag } \\
\text { laag }\end{array}$ \\
\hline $\begin{array}{l}M B O / L L W \text { weg- en waterbouwkund } \\
\text { weg-en waterbouw, SBW }\end{array}$ & 0,23 & gemiddeld \\
\hline $\begin{array}{l}\text { MBO/LLW metaalkunde, } \\
M B O / L L W \text { fijmmechanische techniek } \\
\text { MBO/LLW werktuigbouwkunde } \\
\text { metaal, SOM }\end{array}$ & 0,08 & erg laag \\
\hline $\begin{array}{l}\text { MBO/LLW motorvoertuigentechniek } \\
\text { motorvoertuigen, INNOVAM } \\
\text { carrosserie, VOC }\end{array}$ & $\begin{array}{l}0,31 \\
0,34\end{array}$ & $\begin{array}{l}\text { hoog } \\
\text { hoog }\end{array}$ \\
\hline $\begin{array}{l}\text { MBO/LLW elektrotechniek } \\
\text { elektrotechniek, VEV }\end{array}$ & 0,15 & laag \\
\hline $\begin{array}{l}\text { MBO/LLW grafische techniek } \\
\text { grafici, GOC }\end{array}$ & 0,18 & gemiddeld \\
\hline $\begin{array}{l}\text { MBO/LLW consumptieve techniek } \\
\text { brood en banket, bakkers, SVEB } \\
\text { banketbakken, VBOB }\end{array}$ & $\begin{array}{l}0,04 \\
0,12\end{array}$ & $\begin{array}{l}\text { erg laag } \\
\text { laag }\end{array}$ \\
\hline $\begin{array}{l}\text { MBO/LLW procestechniek } \\
\text { procesindustrie, VAPRO }\end{array}$ & 0,33 & hoog \\
\hline $\begin{array}{l}\text { MBO/LLW textiel- en ledertechniek } \\
\text { textiel, BETEX } \\
\text { schoenindustrie, VAS } \\
\text { confectie, VOC" }\end{array}$ & $\begin{array}{l}0,50 \\
0,21 \\
0,53\end{array}$ & $\begin{array}{l}\text { hoog } \\
\text { gemiddeld } \\
\text { erg hoog }\end{array}$ \\
\hline
\end{tabular}


Tabel 3.11 (vervolg)

Conjunctuurgevoeligheid van de instroom in het leerlingwezen

\begin{tabular}{|c|c|c|}
\hline Opleidingstype/orgaan & conjunctuurgevoeligheid & typering \\
\hline $\begin{array}{l}\text { MBO/LLW haven en vervoer } \\
\text { wegvervoer, SLW } \\
\text { haven en vervoer, SLHV }\end{array}$ & $\begin{array}{l}0,21 \\
0,29\end{array}$ & $\begin{array}{l}\text { gemiddeld } \\
\text { gemiddeld }\end{array}$ \\
\hline $\begin{array}{l}M B O / L L W \text { medisch laboratorium } \\
\text { opticiens, SVGB }\end{array}$ & 0,24 & gemiddeld \\
\hline $\begin{array}{l}\text { MBO/LLW handel } \\
\text { detailhandel, distributie, OVD }\end{array}$ & 0,23 & gemiddeld \\
\hline $\begin{array}{l}M B O / L L W \text { administratiefl } \\
M B O / L L W \text { secretarieel } \\
\text { ECABO }\end{array}$ & 0,42 & hoog \\
\hline $\begin{array}{l}M B O / L L W \text { verzorging } \\
\text { verzorging/dienstverlening, OVDB } \\
\text { kappers, SVK } \\
\text { horeca, OCH }\end{array}$ & $\begin{array}{l}0,12 \\
0,18 \\
0,17\end{array}$ & $\begin{array}{l}\text { laag } \\
\text { gemiddeld } \\
\text { gemiddeld }\end{array}$ \\
\hline
\end{tabular}

De SVEB en de VBOB zijn inmiddels gefuseerd tot de SOBB

- BETEX en VOC zijn inmiddels gefuseerd tot BETEX/VOC

Bron: ROA (1995b) 


\section{Schoolverlaters van de primaire leerlingwezenop- leidingen}

\subsection{Inleiding}

Zoals in hoofdstuk 2 is beschreven is de positie van een leerling die een duale leerweg volgt sterk verschillend van een leerling in het full-time onderwijs. De combinatie van leren en werken impliceert dat de leerling reeds bij intrede in dit onderwijs te maken krijgt met de werking van de arbeidsmarkt. Op de positie gedurende de opleiding is in het vorige hoofdstuk ingegaan. Echter ook na het behalen van het diploma wordt de arbeidsmarktpositie van een LLWer mede bepaald door het duale karakter van zijn scholing. In dit hoofdstuk wordt deze positie besproken. In paragraaf 4.2 worden enkele algemene gegevens over schoolverlaters uit het leerlingwezen gepresenteerd. Paragraaf 4.3 zal ingaan op de arbeidsmarktpositie van deze schoolverlaters. De gegevens in dit hoofdstuk zijn gebaseerd op de enquête onder schoolverlaters van de primaire opleidingen van het Beroepsbegeleidend onderwijs (BBO) uit het studiejaar 1992-1993. De steekproef van schoolverlaters van het BBO is niet representatief, omdat niet alle BBO richtingen zijn meegenomen in de steekproef. $\mathrm{Er}$ is alleen informatie beschikbaar over schoolverlaters van GOC, SOM, VEV, Intechnium, SVK, OVD, ECABO en OVDB.

\subsection{Schoolverlaters van de primaire opleidingen}

Leerlingen die een leerlingwezenopleiding willen gaan volgen schrijven zich eerst bij de school in en vervolgens als ze een praktijkplaats hebben gevonden bij het landelijke orgaan waar de betreffende opleiding onder valt. Het komt echter voor, zoals in het vorige hoofdstuk reeds werd opgemerkt, dat leerlingen geen praktijkplaats kunnen vinden die aan alle eisen voldoet. Bij sommige opleidingen is het dan toch mogelijk om het theoriegedeelte van de opleiding af te maken. Vaak is dat ook afhankelijk van de individuele BBO-school. Het komt dus voor dat leerlingen alleen het theoriegedeelte van de opleiding volgen. Tabel 4.1 geeft het percentage van de schoolverlaters van de primaire opleidingen dat alleen het theoriegedeelte van de opleiding heeft gevolgd. Het blijkt dat alleen bij de SOM, VEV, Intechnium, OVD en ECABO schoolverlaters voorkomen die alleen het theoriegedeelte hebben gevolgd. Ze zijn dan echter niet ingeschreven bij een landelijk orgaan. Omdat deze leerlingen geen volwaardige LLW-opleiding volgen worden ze in dit rapport meestal buiten beschouwing gelaten. Indien ze wel in de analyse betrokken zijn wordt er gesproken van $\mathrm{BBO}$-schoolverlaters en niet van leerlingwezenschoolverlaters. 
Tabel 4.1

Percentage van de BBO-schoolverlaters per orgaan dat naast de opleiding ook nog werk of een stageplaats had in het kader van het leerlingwezen, 1994

\begin{tabular}{|c|c|c|c|c|}
\hline & $\begin{array}{c}\text { betaald werk } \\
\qquad \%\end{array}$ & $\begin{array}{l}\text { werk met } \\
\text { onkostenvergoeding } \\
\qquad \%\end{array}$ & $\begin{array}{c}\text { onbetaald werk } \\
\qquad \%\end{array}$ & $\begin{array}{l}\text { geen werk } \\
\text { alleen theorie } \\
\text { gevolgd } \\
\qquad \%\end{array}$ \\
\hline $\begin{array}{l}\text { GOC } \\
\text { SOM } \\
\text { VEV } \\
\text { Intechnium } \\
\text { SVK } \\
\text { OVD } \\
\text { ECABO } \\
\text { OVDB }\end{array}$ & $\begin{array}{r}100 \\
55 \\
80 \\
95 \\
100 \\
90 \\
35 \\
65\end{array}$ & $\begin{array}{r}0 \\
35 \\
15 \\
0 \\
0 \\
5 \\
50 \\
20\end{array}$ & $\begin{array}{r}0 \\
5 \\
0 \\
0 \\
0 \\
0 \\
10 \\
15\end{array}$ & $\begin{array}{l}0 \\
5 \\
5 \\
5 \\
0 \\
5 \\
5 \\
0\end{array}$ \\
\hline Totaal & 75 & 15 & 5 & 5 \\
\hline
\end{tabular}

Bron: ROA (RUBS)

Tabel 4.1 geeft aan welke positie de leerlingwezenschoolverlaters gedurende hun opleiding hebben gehad. Deze cijfers verschillen op sommige plaatsen van de cijfers in tabel 3.5. Dit verschil kan twee oorzaken hebben. Ten eerste kunnen leerlingen die op het moment van de enquête nog geen betaald werk hebben, op een later moment in de opleiding nog wel betaald werk vinden. Daarnaast hebben de cijfers in tabel 4.1 betrekking op een eerder cohort, zodat verschillen voort kunnen komen uit ontwikkelingen in het aantal praktijkplaatsen.

Tabel 4.2

Percentage van de BBO-schoolverlaters uit het laatste schooljaar dat een diploma heeft behaald, 1994

\begin{tabular}{lc}
\hline & $\%$ \\
\hline GOC & $\%$ \\
SOM & 95 \\
VEV & 65 \\
Intechnium & 70 \\
SVK & 85 \\
OVD & 85 \\
ECABO & 85 \\
OVDB & 80 \\
& 85 \\
Totaal & 75
\end{tabular}

Bron: ROA (RUBS)

Terwijl van alle schoolverlaters van een VEV leerlingwezenopleiding die werk hadden tijdens de opleiding ongeveer $85 \%$ betaald werk had is dat voor mensen die 
in 1994 een VEV opleiding volgde slechts $75 \%$. Dit betekent dat een kleine groep in de loop van de studie alsnog betaald werk krijgt, of dat het moeilijker is geworden om een betaalde arbeidsplaats te vinden. Dat geldt eveneens voor leerlingen van ECABO en OVDB.

Voor SOM, SVK, INTECHNIUM en OVD zijn er geen grote verschillen in deze percentages voor de twee groepen. Maar daarbij moet wel worden bedacht dat voor leerlingen van de SVK geldt dat ze betaald werk moeten hebben om aan de opleiding te beginnen. Een dalend aanbod van leerplaatsen leidt bij dit orgaan automatisch tot een dalend aantal leerlingen.

Tabel 4.2 geeft aan welk deel van de uitstroom van leerlingen in het laatste schooljaar gediplomeerd is. Het numerieke rendement van de opleidingen ligt aanmerkelijk lager, omdat veel leerlingen reeds eerder de opleiding verlaten (zie De Grip e.a. 1993). Het percentage van de schoolverlaters dat een volledig diploma heeft gehaald verschilt nogal per orgaan. Bij het GOC heeft $90 \%$ van de schoolverlaters een volledig diploma behaald, bij de VEV slechts $70 \%$. Een reden voor het niet volledig afmaken van de opleiding kan zijn dat het diploma geen noodzakelijke voorwaarde is om in die branche (dat beroep) aan de slag te komen. In sommige sectoren vinden werkgevers de leerlingwezendiploma's wellicht belangrijker dan in andere. Tabel 4.3 geeft de redenen waarom schoolverlaters hun opleiding niet hebben afgemaakt. Helaas zijn alleen voor schoolverlaters van de SOM genoeg waarnemingen beschikbaar over schoolverlaters zonder diploma. Bijna $30 \%$ van de schoolverlaters is afgehaakt om persoonlijke redenen. Voor leerlingen van de SOM is dat slechts iets meer dan $10 \%$. Meer dan $40 \%$ van de leerlingen van de SOM vond de opleiding te moeilijk. Dat de (nieuwe) werkgever de opleiding niet nodig vond noemt nog geen $5 \%$ van de schoolverlaters als reden. Schoolverlaters van de SOM geven dat nooit als reden op. Deze leerlingen haken dus zelden af omdat ze weinig belang hechten aan een leerlingwezendiploma. De redenen voor vertrek kunnen echter anders zijn bij degenen die reeds vroeg de opleiding verlaten.

Het leerlingwezen is niet altijd de afsluiting van een onderwijstraject. Tabel 4.4 gaat in op het percentage leerlingen dat na het behalen van het diploma verder gaat met een andere leerlingwezenopleiding. Bijna $40 \%$ van de gediplomeerde LLW-schoolverlaters gaat opnieuw een leerlingwezenopleiding volgen. Van de schoolverlaters van Intechnium is dat zelfs $75 \%$. Ook bij SVK is dat percentage hoger dan gemiddeld. Schoolverlaters van ECABO gaan zelden opnieuw een leerlingwezenopleiding volgen. In tabellen over de huidige arbeidsmarktpositie van schoolverlaters uit het leerlingwezen zullen in dit hoofdstuk en in hoofdstuk 5 ook degenen meegenomen worden die opnieuw een leerlingwezenopleiding zijn gaan volgen. Het gaat hier trouwens niet alleen om secundaire opleidingen. Ongeveer $15 \%$ van de schoolverlaters gaat weer opnieuw een primaire opleiding volgen. Dit kan zowel voortkomen 
uit een behoefte aan verbreding van de kwalificaties als uit een aansluitingsprobleem tussen de specifieke richting die men gekozen had en de arbeidsmarkt. $\mathrm{Er}$ zijn op dit punt overigens grote verschillen tussen organen. Schoolverlaters van GOC die opnieuw een leerlingwezenopleiding volgen doen vrijwel altijd een secundaire opleiding. Daarentegen volgt het merendeel van de SVK schoolverlaters die opnieuw een leerlingwezenopleiding doen een primaire opleiding. Het geringe percentage schoolverlaters van ECABO dat zich weer in het leerlingwezen bevindt doet zelfs altijd een primaire opleiding.

Tabel 4.3

Reden van BBO-schoolverlaters uit het laatste studiejaar om leerlingwezenopleiding niet af te maken, 1994

\begin{tabular}{lcc}
\hline & SOM \\
& $\%$ & Totaal \\
& $\%$ \\
\hline & 10 & 30 \\
Persoonlijke reden & 10 & 20 \\
Einde contract, ontslag & 0 & 5 \\
Werkgever vond opleiding niet nodig & 5 & 5 \\
Leerling vond opleiding niet nodig & 10 & 10 \\
Wilde uitsluitend gaan werken & 20 & 10 \\
Wilde andere opleiding gaan doen & 0 & 5 \\
Vanwege de school & 0 & 0 \\
Inhoud vakken niet leuk & 40 & 20 \\
Opleiding te moeilijk & & \\
\hline
\end{tabular}

Bron: ROA (RUBS)

Tabel 4.4

Percentage van de gediplomeerde schoolverlaters uit het leerlingwezen dat opnieuw een leerlingwezenopleiding volgt, 1994

\begin{tabular}{lccc}
\hline & $\begin{array}{c}\text { primair } \\
\%\end{array}$ & $\begin{array}{c}\text { secundair } \\
\%\end{array}$ & $\begin{array}{c}\text { totaal } \\
\%\end{array}$ \\
\hline GOC & 0 & 40 & 45 \\
SOM & 10 & 10 & 25 \\
VEV & 15 & 20 & 35 \\
Intechnium & 35 & 35 & 75 \\
SVK & 40 & 20 & 60 \\
OVD & 20 & 25 & 45 \\
ECABO & 5 & 0 & 5 \\
OVDB & 15 & 5 & 25 \\
Totaal & 15 & 20 & 40 \\
\hline
\end{tabular}

Bron: ROA (RUBS) 


\subsection{Actuele arbeidsmarktpositie van gediplomeerde schoolverlaters uit het leerlingwezen}

Schoolverlaters van een leerlingwezenopleiding verkeren, zoals gezegd, vaak in een andere arbeidsmarktpositie dan schoolverlaters van dagopleidingen. Zij bevinden zich al tijdens de opleiding op de arbeidsmarkt. Het zoeken naar werk vindt al plaats voor dat men met de opleiding begonnen is. In hoofdstuk 2 werd een onderscheid gemaakt tussen bedrijven die leerlingen aannemen met de bedoeling ze na het voltooien van de opleiding in dienst te houden en bedrijven die leerlingen als goedkope arbeidskrachten zien. In het laatste geval is de kans groot dat een schoolverlater na het verlaten van de opleiding niet bij het bedrijf kan blijven werken. Met het beëindigen van het leertraject vervalt immers de reden van aanstelling voor het bedrijf.

In hoofdstuk 3 werd getoond dat de helft van de leerlingen met betaald werk ook een vaste aanstelling heeft. Hieruit kan geconcludeerd worden dat een groot deel van de bedrijven leerlingen opleiden met het oog op de toekomstige baten. Het is daarom interessant om te weten hoe vaak gediplomeerden ook daadwerkelijk blijven werken bij het bedrijf waar ze tijdens de opleiding werkzaam waren. Hierover zijn helaas geen cijfers beschikbaar. Wel is bekend hoeveel schoolverlaters bij het verlaten van de opleiding nog bij hetzelfde bedrijf werkzaam waren. Het is natuurlijk mogelijk dat het arbeidscontract iets langer doorloopt dan de opleiding, maar deze cijfers geven echter toch een goede indicatie van de gebondenheid van de leerling aan het leerbedrijf. Tabel 4.5 laat zien dat $70 \%$ van de schoolverlaters bij het verlaten van de opleiding nog bij hetzelfde bedrijf werkzaam was. Uit de achterliggende cijfers blijkt verder dat ongeveer $10 \%$ bij een ander bedrijf werkte en $20 \%$ geen werk had. Als alleen schoolverlaters in beschouwing worden genomen die betaald werk hadden tijdens de opleiding dan loopt het percentage dat werkzaam was bij hetzelfde bedrijf op tot $85 \%$. Schoolverlaters die tijdens de opleiding hooguit een onkostenvergoeding kregen zijn nog slechts zelden bij hetzelfde bedrijf werkzaam (15\%) terwijl bijna $70 \%$ geen werk had bij het verlaten van de opleiding. Uit deze cijfers blijkt dat als bedrijven leerlingen opleiden uit lange-termijn-overwegingen, ze ook bereid zijn om de leerling een arbeidsovereenkomst aan te bieden. Bedrijven die leerlingen niet vanwege dergelijke lange-termijn-overwegingen aannemen, zijn daartoe veel minder bereid, omdat het dan niet meer lucratief is om leerlingen in dienst te nemen. Geconcludeerd kan worden dat de arbeidsmarktpositie na het behalen van het LLW-diploma van personen die geen arbeidsovereenkomst hadden minder goed is dan van personen die wel een arbeidsovereenkomst hadden. 
Tabel 4.5

Percentage van de gediplomeerde schoolverlaters uit het leerlingwezen per orgaan dat bij het verlaten van de opleiding nog bij hetzelfde bedrijf werkzaam was voor schoolverlaters die betaald werk hadden tijdens de opleiding en voor schoolverlaters die hooguit onbetaald werk of werk met onkostenvergoeding hadden, 1994

\begin{tabular}{|c|c|c|c|}
\hline & betaald werk & $\begin{array}{l}\text { onbetaald werk of } \\
\text { werk met onkosten- } \\
\text { vergoeding } \\
\%\end{array}$ & $\begin{array}{l}\text { alle LLW- } \\
\text { schoolverlaters } \\
\%\end{array}$ \\
\hline GOC & 95 & - & 95 \\
\hline SOM & 80 & 20 & 50 \\
\hline VEV & 80 & - & 70 \\
\hline Intechnium & 95 & - & 95 \\
\hline SVK & 85 & - & 85 \\
\hline OVD & 85 & - & 80 \\
\hline ECABO & - & 10 & 25 \\
\hline OVDB & 95 & - & 70 \\
\hline Totaal & 85 & 15 & 70 \\
\hline
\end{tabular}

Bron: ROA (RUBS)

Schoolverlaters van GOC en Intechnium werken vaker nog bij hetzelfde bedrijf dan schoolverlaters van andere organen. Dat geldt ook wanneer alleen naar schoolverlaters met betaald werk tijdens de opleiding wordt gekeken. Dus kennelijk zijn lange-termijnoverwegingen voor bedrijven die leerlingen via GOC en Intechnium opleiden een belangrijke factor in de beslissing om leerlingen aan te nemen.

Tabel 4.6 geeft het percentage van de schoolverlaters met betaald werk. Schoolverlaters van organen waar men vaker bij het verlaten van de opleiding nog bij het leerbedrijf werkzaam is hebben uiteraard later ook vaker betaald werk. Een groot deel van het verschil in de mogelijkheid om bij het eigen leerbedrijf te blijven werken wordt echter in het baanzoekproces weer gecompenseerd. Zo heeft $80 \%$ van de ECABO-leerlingen werk, terwijl slechts $25 \%$ hiervan bij de oude werkgever is gebleven. Wel gaat het hier minder vaak om vast werk. De ondervraagde gediplomeerde schoolverlaters van Intechium blijken op het moment van enquêtering altijd betaald werk te hebben. Ook schoolverlaters van het SVK, het GOC en het OVD hebben vaak betaald werk. Onder de schoolverlaters bevinden zich echter ook personen die weer opnieuw een leerlingwezenopleiding volgen. Dit kan de resultaten enigszins beïnvloeden omdat bij enkele organen leerlingen vaak onbetaald werk verrichten. Bij organen waar veel schoolverlaters opnieuw een leerlingwezenopleiding volgen en waar tevens veel leerlingen onbetaald werk of werk tegen onkostenvergoeding verrichten zal het percentage van de schoolverlaters met betaald werk gemiddeld lager liggen. Het percentage van de geënquêteerde schoolverlaters met betaald werk dat tevens een vaste baan heeft is opnieuw hoog 
bij Intechnium en het GOC. Opvallend is dat schoolverlaters van het OVDB met een betaalde baan altijd een vaste aanstelling hebben.

Tabel 4.6

Percentage van de gediplomeerde schoolverlaters uit het leerlingwezen dat betaald werk heeft en het percentagae dat vast werk heeft, 1994

\begin{tabular}{lcc}
\hline & $\begin{array}{c}\text { betaald werk } \\
\%\end{array}$ & $\begin{array}{c}\text { Waarvan vast werk } \\
\%\end{array}$ \\
\hline GOC & 95 & 90 \\
SOM & 75 & 80 \\
VEV & 80 & - \\
Intechnium & 100 & 95 \\
SVK & 100 & 75 \\
OVD & 90 & 80 \\
ECABO & 80 & 50 \\
OVDB & 85 & 100 \\
Totaal & 85 & 80 \\
\hline
\end{tabular}

Bron: ROA (RUBS)

Tabel 4.7

Gemiddeld bruto uurloon van schooverlaters uit het leerlingwezen, 1994

\begin{tabular}{lcc}
\hline & $\begin{array}{l}\text { gemiddeld uurloon } \\
\text { in guldens }\end{array}$ & standaardafwijking \\
\hline GOC & 17,10 & 4,6 \\
SOM & 13,30 & 5,6 \\
VEV & 16,40 & 4,7 \\
Intechnium & 16,00 & 6,0 \\
SVK & 9,40 & 2,6 \\
OVD & 10,80 & 5,2 \\
ECABO & 9,50 & 3,6 \\
OVDB & 14,40 & 6,1 \\
& & \\
Gemiddeld & 13,00 & 5,6 \\
\hline
\end{tabular}

Bron: ROA (RUBS)

De lonen van de LLW-schoolverlaters verschillen nogal tussen de organen. Tabel 4.7 laat dit zien. De Ionen van schoolverlaters van ECABO en SVK zijn gemiddeld lager dan de lonen van schoolverlaters van andere organen. Schoolverlaters van het GOC hebben gemiddeld het hoogste loon. Natuurlijk worden ook hier de cijfers enigszins beïnvloed doordat ook schoolverlaters die opnieuw een leerlingwezen opleiding volgen in beschouwing zijn genomen. Bij organen waar veel schoolverlaters weer opnieuw een leerlingwezenopleiding volgen kan het gemiddelde loon wat omlaag zijn getrokken. Het blijkt echter dat over het algemeen het gemiddelde 
loon voor schoolverlaters die opnieuw een leerlingwezenopleiding volgen weinig afwijkt van dat van andere schoolverlaters.

Tabel 4.8

Percentage onderbenutting van de gediplomeerde schoolverlaters uit het leerlingwezen, 1994

\begin{tabular}{lc}
\hline & $\%$ \\
\hline GOC & $\% 5$ \\
SOM & 50 \\
VEV & 60 \\
Intechnium & 65 \\
SVK & 55 \\
OVD & 75 \\
ECABO & 65 \\
OVDB & 75 \\
Totaal & 65 \\
\hline
\end{tabular}

Bron: ROA (RUBS)

Omdat de praktijkcomponent in het leerlingwezen van wezenlijk belang is voor de opleiding, mag verwacht worden dat de opleiding doorgaans - voor degenen die in hun eigen vakgebied werkzaam blijven - goed aansluit op de baan die men na afloop verwerft. Tabel 4.8 geeft het percentage van de schoolverlaters dat aangeeft dat het vereiste opleidingsniveau voor hun functie lager is dan het primaire leerlingwezen. Uit de tabel blijkt echter dat meer dan de helft van de schoolverlaters werkzaam is onder hun niveau. Dit hoge percentage wordt mogelijk verklaard doordat in het leerlingwezen relatief veel schoolverlaters na de opleiding bij hun leerbedrijf blijven werken. Binnen dit bedrijf zal op het moment van diplomering niet onmiddellijk een formele functieverhoging plaatsvinden. De leerlingen geven dan bij de vraag over het vereiste functieniveau voor hun huidige functie de ingangseis om met de leer-arbeidsplaats te beginnen (Smoorenburg en Van der Velden, 1995). De functionaliteit van de in het onderwijs verworven kwalificaties zouden daarom bij het leerlingwezen op een meer genuanceerde wijze gemeten moeten worden. Bij schoolverlaters van de OVDB en de OVD is de gemiddelde onderbenutting overigens hoger dan bij andere organen. De onderbenutting is het laagst voor leerlingen van de VEV.

Omdat er geen informatie beschikbaar is over de wijze waarop de verworven kwalificaties doorwerken in de aard van de functie, is de concrete vraag of mensen in hun eigen vakgebied werkzaam blijven wellicht van grotere betekenis. De gedachte is dat schoolverlaters uit het leerlingwezen niet zo veel uitwijkmogelijkheden hebben omdat ze weinig algemene vakken hebben gehad tijdens de opleiding. Tabel 4.9 laat zien dat slechts $5 \%$ van de schoolverlaters zegt in een beroep te 
werken waarvoor een andere vakrichting werd vereist. Opvallend genoeg zeggen schoolverlaters van VEV en Intechnium dat vaker dan gemiddeld. Veel schoolverlaters geven aan dat geen specifieke vakrichting werd vereist voor hun huidige beroep. Ook hier kan echter de vertekening optreden doordat schoolverlaters die bij hetzelfde bedrijf zijn blijven werken uitgaan van het moment dat ze aan de opleiding begonnen. Dit argument geldt overigens niet voor schoolverlaters van ECABO omdat zij meestal niet bij hetzelfde bedrijf in dienst zijn gebleven na het afronden van de opleiding.

Tabel 4.9

Percentage van de gediplomeerde schoolverlaters uit het leerlingwezen per orgaan dat niet in de eigen vakrichting werkzaam is, 1994

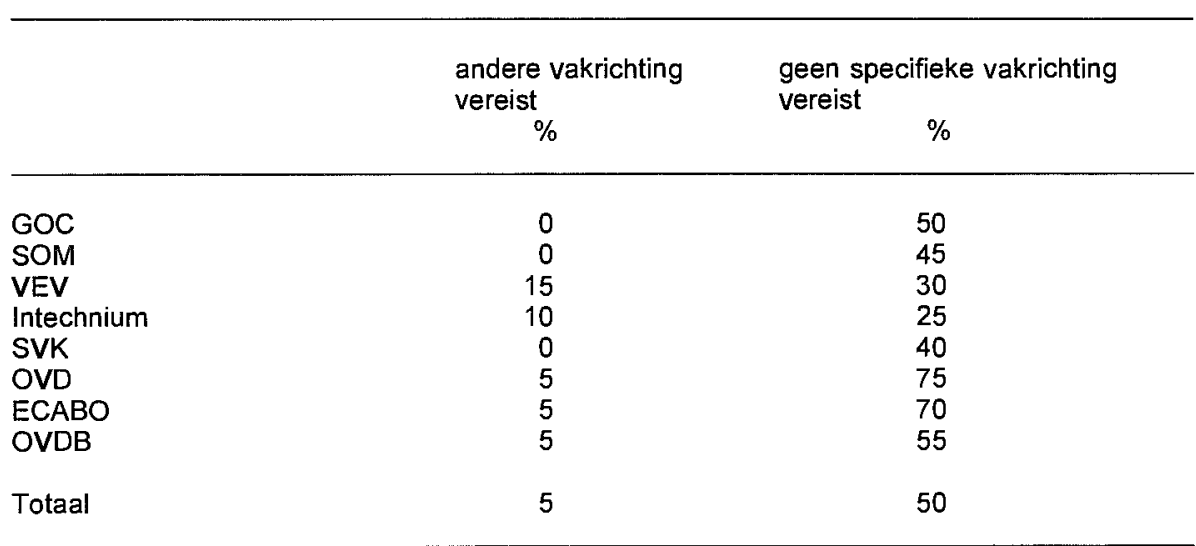

Bron: ROA (RUBS)

Al met al vindt - zoals wordt weergegeven in tabel 4.10 - bijna $85 \%$ van de schoolverlaters dat hun opleiding goed aansluit op hun huidige baan. Bij de SVK en de OVDB ligt dat percentage iets hoger dan gemiddeld. Bij ECABO vindt slechts iets meer dan de helft van de schoolverlaters dat er sprake is van een goede aansluiting. Dat zal gedeeltelijk samenhangen met het feit dat schoolverlaters van ECABO niet in hun eigen vakgebied werkzaam zijn. Anderzijds is het ook mogelijk dat leerlingen van ECABO minder leren op de praktijkplaats omdat het niet altijd een echte arbeidsplaats is, maar bijvoorbeeld een leerplaats bij een simulatiebedrijf.

Schoolverlaters van de technische leerlingwezenopleidingen lijken over het algemeen een wat betere arbeidsmarktpositie te hebben dat schoolverlaters van de andere richtingen. De arbeidsmarktpositie van schoolverlaters van GOC en Intechnium is op meerdere punten beter dan dat van schoolverlaters van andere organen. Ook schoolverlaters van OVDB hebben in verhouding een goede arbeidsmarktpositie. Schoolverlaters van ECABO lijken een slechtere arbeidsmarkpositie te hebben. Deze verschillen ontstaan al voordat leerlingen met de opleiding beginnen. Het is voor ECABO-leerlingen veel moeilijker om een betaalde leer-arbeidsplaats te 
vinden, en de kans dat ze bij hun leerbedrijf in dienst kunnen blijven na het voltooien van de opleiding is ook veel kleiner dan voor leerlingen van andere organen. Als ze na het voltooien van de opleiding werk hebben gevonden dan is dat veel minder vaak vast werk. Verder liggen de lonen voor schoolverlaters uit deze richting gemiddeld ook lager dan bij andere organen.

Tabel 4.10

Percentage van de gediplomeerde schoolverlaters uit het leerlingwezen per orgaan dat vindt dat de opleiding goed aansluit op de huidige baan, 1994

SOM

VEV

Intechnium

SVK

OVD

ECABO

OVDB

Totaal

Bron: ROA (RUBS) 


\section{Verschillen in arbeidsmarktpositie tussen school- verlaters uit het leerlingwezen, KMBO en MBO}

\subsection{Inleiding}

In dit hoofdstuk wordt de arbeidsmarktpositie van schoolverlaters van de primaire opleidingen in het leerlingwezen vergeleken met die van MBO'ers en KMBO'ers. De vergelijkingen worden gemaakt naar opleidingsrichting. Opleidingen in de drie onderwijsvormen zijn vaak niet volledig vergelijkbaar. Per opleidingsrichting voor het leerlingwezen wordt daarom naar de meest verwante opleidingsrichting op KMBOen MBO-niveau gezocht. Appendix B geeft een overzicht van de resulterende opleidingsindeling.

In paragraaf 5.2 wordt ingegaan op verschillen in de actuele arbeidsmarktpositie tussen schoolverlaters uit het leerlingwezen en schoolverlaters van het MBO en $\mathrm{KMBO}$. Hierbij wordt gekeken naar werkloosheid onderbenutting en lonen. Vervolgens wordt in paragraaf 5.3 onderzocht hoe goed LLW-, KMBO- en MBO-opleidingen aansluiten op het beroep van de schoolverlaters.

\subsection{Verschillen in arbeidsmarktpositie}

\section{Werkloosheid}

Tabel 5.1 geeft de werkloosheid onder schoolverlaters van het LLW, KMBO en MBO. Het betreft het aantal werkzoekenden zonder baan. De werkloosheid is het hoogst onder schoolverlaters van het KMBO. Ook onder schoolverlaters van het MBO is de werkloosheid hoger dan onder schoolverlaters uit het leerlingwezen. Dat is gedeeltelijk te verklaren door het feit dat veel schoolverlaters uit het leerlingwezen blijven werken bij het bedrijf waar ze zijn opgeleid terwijl KMBO'ers en MBO'ers voor het eerst de arbeidsmarkt betreden. In die zin sluit het leerlingwezen dus inderdaad goed aan bij het vervolg op de arbeidsmarkt. Hierbij dient men zich echter wel te realiseren dat, zoals reeds werd opgemerkt, bij het leerlingwezen de aansluitingsproblematiek zich gedeeltelijk verplaatst naar het begin van de studie. Niet iedereen die dat wil weet immers een leer-arbeidsplaats te bemachtigen.

De werkloosheid onder LLW-schoolverlaters is het hoogst in de richtingen metaaltechniek, elektrotechniek en economische en administratieve beroepen. Dat zijn ook precies de richtingen waarin leerlingen die een LLW-opleiding volgen vaker dan gemiddeld geen betaald werk hebben in het kader van hun opleiding. De eveneens hoge werkloosheidspercentages voor $\mathrm{KMBO}$ - en MBO-schoolverlaters uit deze 
opleidingsrichtingen wijzen er overigens op dat de problemen zich over de hele linie voordoen en niet specifiek zijn voor het leerlingwezen.

Opvallend is de lage werkloosheid onder LLW-schoolverlaters uit de richtingen haarkappen en verzorgende en dienstverlenende beroepen. Dit is vooral opmerkelijk wanneer wordt bedacht dat leerlingen bij de OVDB (het orgaan dat de opleidingen voor verzorgende en dienstverlenende beroepen verzorgt) relatief vaak onbetaald werk hebben tijdens de opleiding en ook vaak niet bij dezelfde instelling in dienst blijven na het verlaten van de opleiding. Hun positie gedurende de opleiding leek daardoor op zich op een zwakke arbeidsmarktpositie te duiden. In vergelijking met MBO- en KMBO-schoolverlaters is hun arbeidsmarktpositie op dit punt echter goed.

Tabel 5.1

Werkloosheid per opleidingstype en opleidingsrichting onder schoolverlaters, 1994

\begin{tabular}{lccc}
\hline & $\begin{array}{l}\text { LLW } \\
\%\end{array}$ & $\begin{array}{l}\text { KMBO } \\
\%\end{array}$ & $\begin{array}{l}\text { MBO } \\
\%\end{array}$ \\
\hline Opleidingsrichting & & & \\
Technisch: metaaltechniek & 10 & 7 & 16 \\
Technisch: elektrotechniek & 9 & 19 & 16 \\
Technisch: installatietechniek & 0 & 6 & - \\
Technisch: consumptieve techniek & - & 7 & 8 \\
Technisch: grafische techniek & 4 & - & 11 \\
Technisch: overig & 4 & 11 & 14 \\
Ec-adm: detailhandel & 5 & 10 & 18 \\
Ec-adm: econ. \& adm. beroepen & 7 & 19 & 5 \\
Verz: verz.\& dienstverlenende beroepen & 3 & 19 & 10 \\
Verz: haarkappen & 0 & - & 12 \\
Totaal & 5 & 15 & \\
\hline
\end{tabular}

Bron: ROA (RUBS)

\section{Beroepenspreiding}

De leerlingwezenopleidingen zijn over het algemeen veel beroepsspecifieker dan KMBO- en MBO-opleidingen. Er worden vooral vaardigheden aangeleerd die van direct belang zijn voor het uitoefenen van het beroep waarvoor men wordt opgeleid. De MBO-opleidingen leren daarentegen ook meer algemene vaardigheden aan. Dat betekent dat de directe aansluiting opleiding en beroep beter is voor leerlingwezenschoolverlaters. De keerzijde hiervan is echter dat MBO'ers meer uitwijkmogelijkheden hebben naar andere beroepen. Tabel 5.2 geeft de beroepenspreiding voor schoolverlaters uit het LLW, KMBO en MBO. De Gini-Hirschman spreidingsindex geeft de beroepenspreiding van een opleiding. Deze index neemt een waarde aan tussen 0 en 1 . Als iedereen met een bepaalde opleiding in hetzelfde beroep 
werkzaam is dan is de Gini-Hirschmanindex gelijk aan 0 . Bij een gelijkmatige spreiding is de index gelijk aan 1 . Het blijkt dat voor vrijwel alle opleidingsrichtingen geldt dat LLW-schoolverlaters een lagere beroepenspreiding hebben dan KMBO'ers en MBO'ers. Dat maakt mensen met een leerlingwezenopleiding inderdaad kwetsbaarder voor conjuncturele ontwikkelingen dan KMBO'ers en MBO'ers.

Tabel 5.2

Uitwijkmogelijkheden naar verschillende beroepsgroepen: Gini-Hirschman spreidingsindex, 1994

\begin{tabular}{llll}
\hline & LLW & KMBO & MBO \\
\hline Opleidingsrichting & & & \\
& & & \\
Technisch: metaaltechniek & 0,84 & 0,91 & 0,90 \\
Technisch: elektrotechniek & 0,77 & 0,87 & 0,90 \\
Technisch: installatietechniek & 0,48 & 0,88 & nvt \\
Technisch: consumptieve techniek & 0,72 & 0,46 & 0,83 \\
Technisch: grafische techniek & 0,57 & - & 0,89 \\
Technisch: overig & 0,85 & 0,88 & 0,93 \\
Ec-adm: detailhandel & 0,69 & 0,64 & 0,73 \\
Ec-adm: econ. \& adm. beroepen & 0,75 & 0,84 & 0,81 \\
Verz: verz.\& dienstverlenende beroepen & 0,47 & 0,88 & 0,83 \\
Verz: haarkappen & 0,28 & - & 0,52 \\
\hline
\end{tabular}

Bron: ROA (RUBS)

\section{Onderbenutting}

Schoolverlaters uit het leerlingwezen werken relatief vaak beneden hun opleidingsniveau. Tabel 5.3 geeft hiervan een overzicht. De tabel geeft aan welk deel van de werkenden onder het eigen opleidingsniveau werkzaam is. Bijna $65 \%$ van de schoolverlaters uit het leerlingwezen werkt in een beroep waarvan het vereiste functieniveau lager is dan het primair leerlingwezen. Van de KMBO-schoolverlaters werkt bijna $55 \%$ onder zijn niveau. Voor MBO-schoolverlaters is dit ongeveer $40 \%$. In hoofdstuk 4 werd het hoge percentage onderbenutting voor LLW-schoolverlaters al verklaard door de mogelijkheid dat LLW-schoolverlaters uitgaan van het vereiste functieniveau op het moment dat ze met de opleiding begonnen in plaats van het functieniveau op het moment dat ze de opleiding hebben afgerond. Veel leerlingwezenschoolverlaters blijven immers bij hun leerbedrijf werkzaam.

Alleen bij schoolverlaters uit de opleidingsrichting haarkappen worden MBO'ers vaker onderbenut dan LLW-schoolverlaters. Dit bevestigt opnieuw het beeld dat in de kappersbranche de leerlingwezenopleiding zeer goed aansluit op de vraag naar kappers. Bij MBO'ers uit de richting economische en administratieve beroepen is de onderbenutting het laagst. Het is daarom opvallend dat LLW- en KMBO-schoolver- 
laters uit deze richting wel relatief vaak onder hun niveau werken. Uit tabel 5.1 bleek al dat de werkloosheid onder MBO-schoolverlaters uit de richting economische administratieve beroepen erg hoog is. Omgekeerd gaat het hoge percentage onderbenutting van schoolverlaters uit de richting verzorgende en dienstverlenende beroepen voor zowel LLW'ers als MBO'ers gepaard met een relatief laag werkloosheidspercentage. Er bestaat kennelijk een trade-off tussen de kans een baan te vinden en het niveau van dit werk.

Tabel 5.3

Percentage onderbenutting van de gediplomeerde schoolverlaters, 1994

\begin{tabular}{lccc}
\hline Opleidingsrichting & $\begin{array}{l}\text { LLW } \\
\%\end{array}$ & $\begin{array}{l}\text { KMBO } \\
\%\end{array}$ & $\begin{array}{l}\text { MBO } \\
\%\end{array}$ \\
\hline Technisch: metaaltechniek & 60 & 50 & 45 \\
Technisch: elektrotechniek & 40 & 40 & 35 \\
Technisch: installatietechniek & 65 & - & - \\
Technisch: consumptieve techniek & - & 25 & 30 \\
Technisch: grafische techniek & 55 & - & 20 \\
Technisch: overig & 65 & 40 & 30 \\
Ec-adm: detailhandel & 75 & 70 & 50 \\
Ec-adm: econ. \& adm. beroepen & 65 & 55 & 20 \\
Verz: verz.\& dienstverlenende beroepen & 75 & 70 & 50 \\
Verz: haarkappen & 55 & - & 70 \\
Totaal & 65 & 55 & 35 \\
\hline
\end{tabular}

Bron: ROA (RUBS)

\section{Lonen}

Tabel 5.4 geeft het gemiddelde bruto uurloon voor LLW-, KMBO- en MBO-schoolverlaters. Voor de meeste opleidingsrichtingen geldt dat MBO'ers gemiddeld het meest verdienen en KMBO'ers het minst. In de richting elektrotechniek verdienen LLW-schoolverlaters echter gemiddeld significant meer dan KMBO- en MBOschoolverlaters.

Tabel 5.5 geeft de geschatte coëfficiënten van de loonvergelijkingen voor LLW'ers, KMBO'ers en MBO'ers. De afhankelijke variabele is het logaritme van het bruto uurloon. Het bruto uurloon is afhankelijk van de leeftijd, de opleidingsrichting, geslacht, de grootte van het bedrijf, het aantal uren dat iemand per week werkt en het hebben van een vast arbeidscontract. 
Tabel 5.4

Gemiddeld bruto uurloon van schoolverlaters, 1994

\begin{tabular}{|c|c|c|c|c|c|c|}
\hline \multirow[b]{2}{*}{ Opleidingsrichting } & \multicolumn{2}{|c|}{ LLW } & \multicolumn{2}{|c|}{ KMBO } & \multicolumn{2}{|c|}{ MBO } \\
\hline & $f$ & $\begin{array}{c}\text { standaard- } \\
\text { afwijking }\end{array}$ & $f$ & $\begin{array}{l}\text { standaard- } \\
\text { afwijking }\end{array}$ & $f$ & $\begin{array}{l}\text { standaard- } \\
\text { afwijking }\end{array}$ \\
\hline Metaaltechniek & 13,40 & $(5,7)$ & 13,70 & $(10,9)$ & 14,90 & $(3,7)$ \\
\hline Elektrotechniek & 16,40 & $(4,7)$ & 10,30 & $(4,0)$ & 13,40 & $(3,5)$ \\
\hline Installatietechniek & 13,30 & $(5,7)$ & 16,00 & $(6,0)$ & - & - \\
\hline Consumptieve techniek & - & - & 10,50 & $(3,2)$ & 15,70 & $(3,2)$ \\
\hline Grafische techniek & 17,00 & $(4,6)$ & - & - & 15,30 & $(3,0)$ \\
\hline Technisch overig & 15,80 & $(6,6)$ & 11,00 & $(5,8)$ & 14,40 & $(5,0)$ \\
\hline Detailhandel & 11,30 & $(5,8)$ & 10,70 & $(4,5)$ & 11,80 & $(4,4)$ \\
\hline Economisch-administratief & 9,50 & $(3,6)$ & 9,50 & $(2,5)$ & 11,20 & $(3,1)$ \\
\hline Verzorgend-dienstverlenend & 14,40 & $(6,1)$ & 9,90 & $(2,7)$ & 12,70 & $(3,6)$ \\
\hline Haarkappen & 9,40 & $(2,6)$ & - & - & 10,00 & $(2,2)$ \\
\hline Totaal & 12,80 & $(5,6)$ & 10,20 & $(4,5)$ & 12,40 & $(3,8)$ \\
\hline
\end{tabular}

Bron: ROA (RUBS)

Tabel 5.5

Loonvergelijkingen voor schoolverlaters, 1994

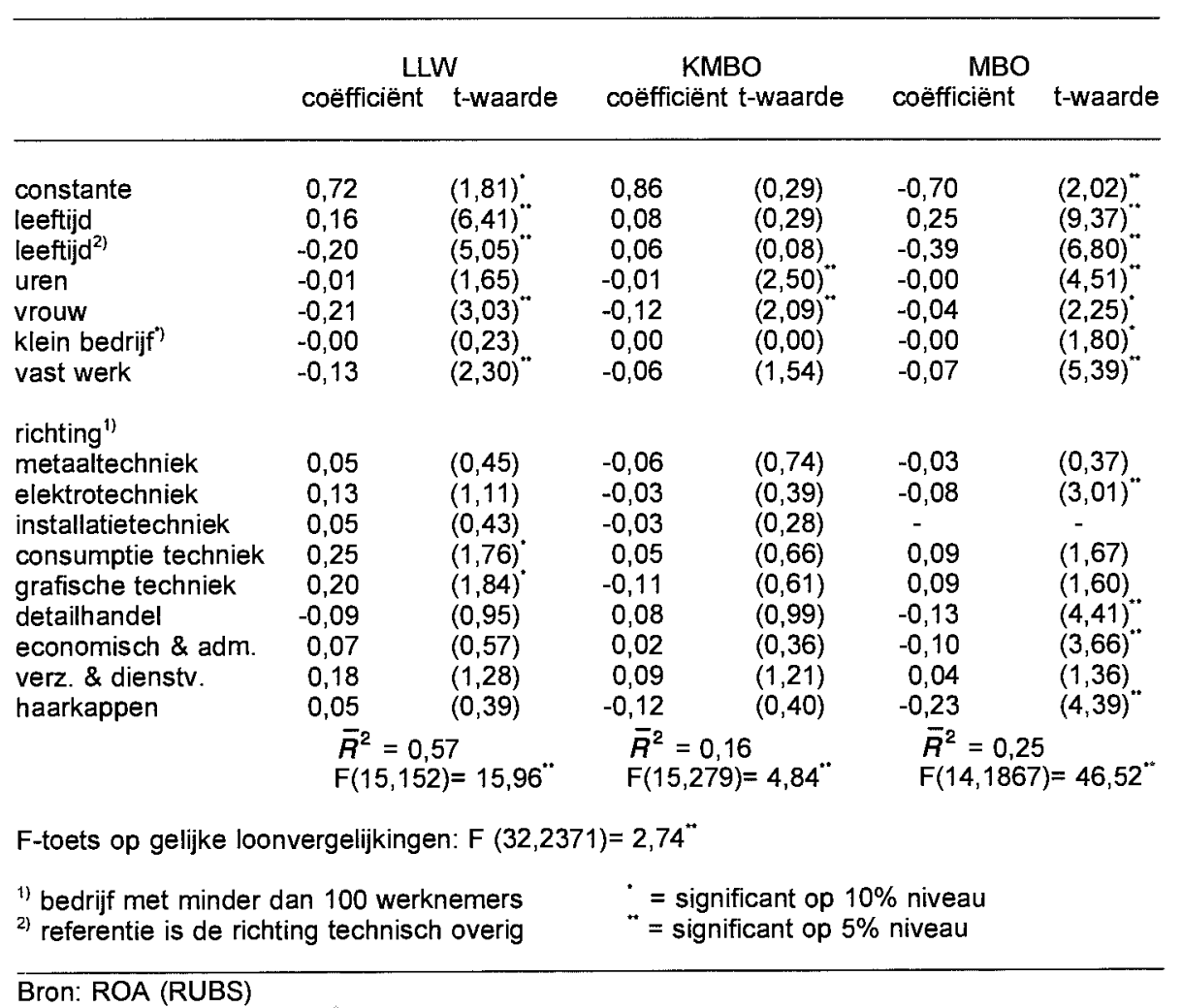


Tabel 5.6

Verschillen tussen loonvergelijkingen: het LLW ten opzichte van het KMBO en ten opzichte van het MBO, 1994

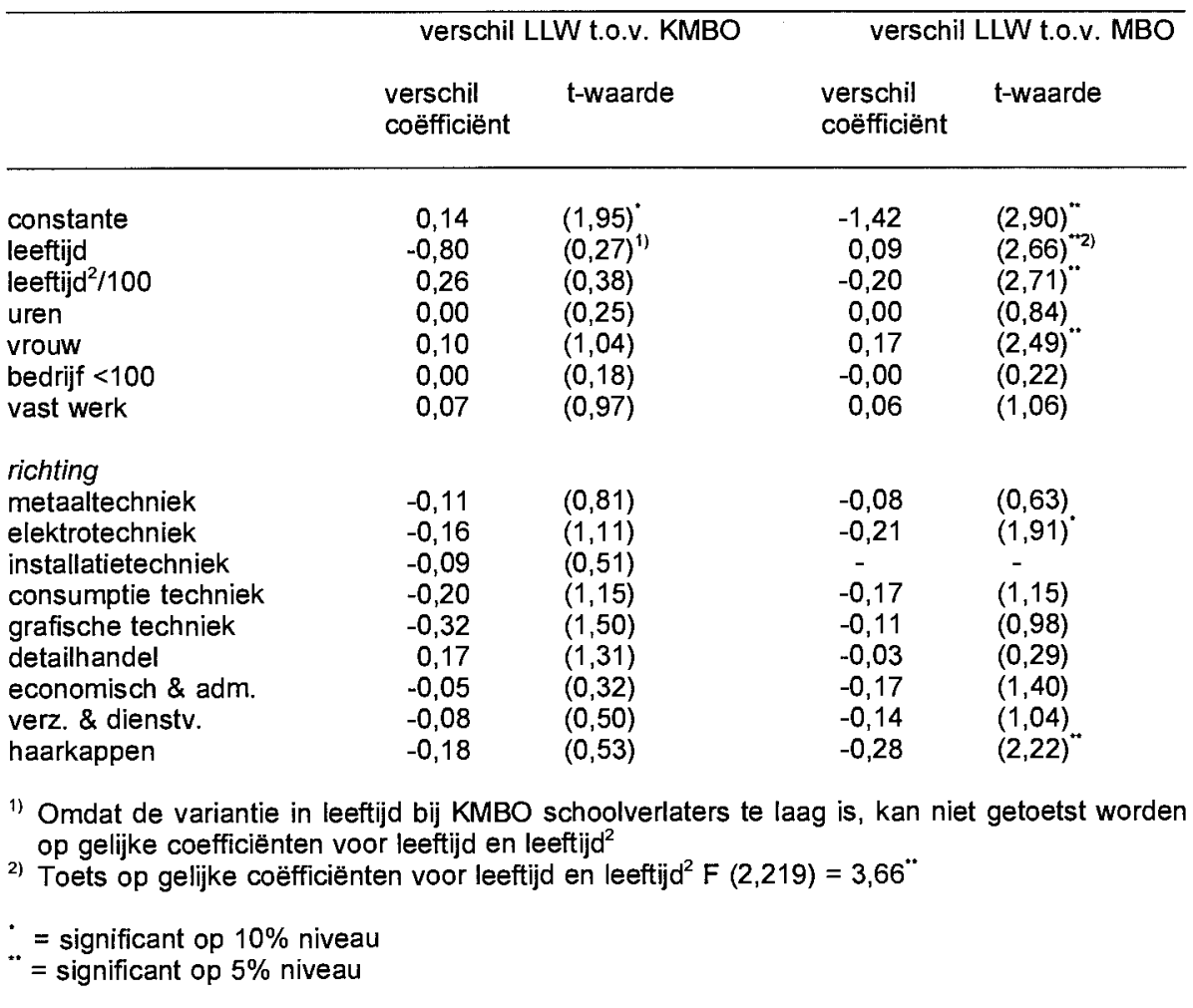

Bron: ROA (RUBS)

In tabel 5.6 wordt getoets of de coëfficiënten van de loonvergelijking voor LLWschoolverlaters significant verschillen van de coëfficiënten van de loonvergelijkingen van $\mathrm{MBO}$ - en KMBO-schoolverlaters. De tabel geeft het verschil tussen de parameters van de loonvergelijkingen van LLW-schoolverlaters en KMBO- en MBOschoolverlaters. Een positief verschil betekent dat de invloed van de variabele op het loon groter is voor LLW-schoolverlaters dan voor KMBO- of MBO-schoolverlaters. Leeftijd is een belangrijke verklarende variabele voor zowel het LLW als het MBO. De leeftijd lijkt geen significante invloed te hebben op het loon van KMBOschoolverlaters. De variantie in de leeftijd van KMBO-schoolverlaters is echter te laag om een significante invloed van de leeftijd op het loon te kunnen vinden. Het blijkt dat vrouwen zowel bij de schoolverlaters van het LLW, KMBO als het MBO gemiddeld minder verdienen dan mannen. Het verschil in bruto-uurloon tussen mannen en vrouwen is echter groter voor LLW-schoolverlaters dan voor KMBO- en MBO-schoolverlaters. MBO-schoolverlaters die bij een bedrijf met minder dan 100 werknemers werkzaam zijn, verdienen gemiddeld minder dan schoolverlaters die bij 
grote bedrijven werken. Bij LLW- en KMBO-schoolverlaters wordt geen significante invloed van de bedrijfsgrootte op het loon gevonden. Het feit dat iemand vast werk heeft, heeft een significante negatieve invloed op het loon van zowel LLW- als MBO-schoolverlaters.

\subsection{Aansluiting opleiding en beroep}

Tabel 5.7 geeft aan hoe schoolverlaters denken over de aansluiting tussen hun opleiding en werk. Ruim $80 \%$ van de schoolverlaters uit het leerlingwezen vindt dat hun opleiding voldoende tot goed op hun huidige baan aansluit. Voor KMBO- en MBO-schoolverlaters in de overeenkomstige opleidingsrichtingen is dat respectievelijk $70 \%$ en $75 \%$. Deze betere aansluiting tussen opleiding en beroep voor schoolverlaters uit het leerlingwezen komt overeen met de verwachtingen. Schoolverlaters uit het leerlingwezen blijven na het voltooien van hun opleiding immers vaak bij hetzelfde bedrijf werkzaam als waar ze opgeleid zijn. Ze hebben hun huidige beroep in de praktijk bij het betreffende bedrijf geleerd en daarom zal de aansluiting over het algemeen goed zijn.

Tabe/ 5.7

Percentage van de gediplomeerde schoolverlaters dat vind dat studie voldoende tot goed op het huidige werk aansluit, 1994

\begin{tabular}{lccc}
\hline & $\begin{array}{l}\text { LLW } \\
\%\end{array}$ & $\begin{array}{l}\text { KMBO } \\
\%\end{array}$ & $\begin{array}{l}\text { MBO } \\
\%\end{array}$ \\
\hline Opleidingsrichting & & & \\
Technisch: metaaltechniek & 75 & 60 & 55 \\
Technisch: elektrotechniek & 85 & 70 & 60 \\
Technisch: installatietechniek & 85 & - & - \\
Technisch: consumptieve techniek & 80 & 65 & 65 \\
Technisch: grafische techniek & 90 & - & 70 \\
Technisch: overig & 85 & 75 & 70 \\
Ec-adm: detailhandel & 55 & 70 & 70 \\
Ec-adm: econ. \& adm. beroepen & 90 & 70 & 80 \\
Verz: verz.\& dienstverlenende beroepen & 95 & - & 65 \\
Verz: haarkappen & 80 & 70 & 75 \\
Totaal & & & 70 \\
\hline
\end{tabular}

Bron: ROA (RUBS)

Een uitzondering vormen opnieuw LLW-schoolverlaters uit de richting economisch en administratieve beroepen. Slechts iets meer dan de helft van deze schoolverlaters vindt dat de gevolgde opleiding goed aansluit op het huidige beroep. Voor KMBO- en MBO-schoolverlaters uit deze richting is dat ruim $70 \%$. Een slechte aansluiting betekent overigens niet per definitie dat de opleiding inhoudelijk te kort 
schiet. Het is ook mogelijk dat de aansluiting minder goed is omdat schoolverlaters in een ander vakgebied zijn gaan werken dan waarvoor ze zijn opgeleid. In het vorige hoofdstuk bleek al dat schoolverlaters van ECABO, het orgaan dat opleidt voor economische en administratieve beroepen, zelden in een andere vakrichting werkzaam zijn, maar wel vaak in beroepen waarvoor geen specifieke vakrichting vereist is. Het is dus mogelijk dat LLW-schoolverlaters uit economische en administratieve richtingen inderdaad vaak werkzaam zijn in beroepen waar ze niet voor zijn opgeleid.

Leerlingwezenopleidingen zijn over het algemeen vakspecifieker van aard dan MBO-opleidingen. Een leerlingwezenopleiding bevat voornamelijk beroepsvoorbereidende vakken en veel minder algemeen vormende vakken zoals vreemde talen, wiskunde of maatschappijleer. MBO-opleidingen bevatten naast de beroepsvoorbereidende vakken wel veel meer algemene vakken. MBO'ers hebben echter in tegenstelling tot LLWers veel minder mogelijkheden gehad om vakspecifieke vaardigheden in de praktijk te leren. Als een MBO'er en een LLWer in eenzelfde beroep werkzaam zijn, is het te verwachten dat een LLWers meer knelpunten ervaart ten aanzien van tekortschietende algemene vaardigheden. Een MBO'er zal meer knelpunten ervaren door tekortschietende vakspecifieke vaardigheden.

KMBO'ers en MBO'ers zullen echter vaak in andere beroepen werkzaam zijn dan LLW-schoolverlaters. De beroepenspreiding is voor MBO'ers groter dan voor LLWschoolverlaters. Een tekort aan algemene vaardigheden uit zich daardoor wellicht eerder in het feit dat slechts een beperkt aantal banen toegankelijk zijn voor LLWers en minder in de aansluiting tussen de gevolgde opleiding en het beroep waarin men werkzaam is. Ook op langere termijn kan deze geringe flexibiliteit een belemmering voor de carrière vormen. Het tegenovergestelde geldt voor MBO'ers. Ze beheersen de vaktechnische vaardigheden wellicht minder goed dan mensen met een leerlingwezenopleiding, maar zijn ook minder vaak in zuivere vaktechnische functies werkzaam. MBO'ers zijn daardoor minder afhankelijk van deze specifieke functies.

Om een beeld te krijgen van het verband tussen opleiding en gevraagde kwalificatie wordt in tabel 5.8 gekeken naar het percentage van de schoolverlaters dat vindt dat tijdens de opleiding meer aandacht had moeten worden besteed aan praktijkorientatie of stage. Gelet op het meer theoretisch karakter van de opleiding mag verwacht worden dat met name KMBO'ers en MBO'ers vaak zullen zeggen dat meer aandacht had moeten worden besteed aan praktijkoriëntatie of stage. MBO'ers zeggen dat inderdaad vaker dan LLWers, hoewel het verschil opvallend klein is. Voor het KMBO is dit percentage zelf gelijk aan dat voor het leerlingwezen. Het percentage van de LLWers dat van mening is dat meer aandacht aan praktijk oriëntatie of stage had moeten worden geschonken is overigens verrassend hoog. 
Dat geldt met name voor LLW-schoolverlaters uit de richtingen metaaltechniek en grafische techniek.

Opvallend is ook dat LLW-schoolverlaters uit de richting economische \& administratieve beroepen niet vaker dan gemiddeld aangegeven dat meer aandacht aan praktijk-oriëntatie en stage moet worden geschonken, terwijl ze wel veel vaker ontevreden zijn over de aansluiting van hun studie op hun beroep. Blijkbaar ervaren deze schoolverlaters met name een tekort aan algemene vaardigheden die niet in de praktijk aangeleerd kunnen worden. Uit achterliggende cijfers blijkt ook dat LLWschoolverlaters uit deze richting vaak aangeven dat tijdens hun opleiding meer aandacht had moeten worden geschonken aan zaken als foutloos schrijven en rapporten schrijven. Dit zijn aspecten die over het algemeen beter in theorielessen aangeleerd kunnen worden. Toch missen MBO'ers uit deze opleidingsrichting vaak de praktijkoriëntatie voor de beroepen waarvoor ze zijn opgeleid. Dat duidt erop dat het leerlingwezen wel een nuttige opleidingsvorm is voor economische en administratieve beroepen maar dat theoretische vakken niet genoeg aandacht krijgen zodat er knelpunten in de aansluiting opleiding en beroep ontstaan.

Tabel 5.8

Percentage van de gediplomeerde schoolverlaters dat vind dat meer aandacht had moeten worden besteed aan praktijkorientatie of stage, 1994

\begin{tabular}{|c|c|c|c|}
\hline & $\begin{array}{l}\text { LLW } \\
\%\end{array}$ & $\begin{array}{l}\text { KMBO } \\
\%\end{array}$ & $\begin{array}{l}\text { MBO } \\
\%\end{array}$ \\
\hline \multicolumn{4}{|l|}{ Opleidingsrichting } \\
\hline $\begin{array}{l}\text { Technisch: metaaltechniek } \\
\text { Technisch: elektrotechniek } \\
\text { Technisch: installatietechniek } \\
\text { Technisch: consumptieve techniek } \\
\text { Technisch: grafische techniek } \\
\text { Technisch: overig } \\
\text { Ec-adm: detailhandel } \\
\text { Ec-adm: econ. \& adm. beroepen } \\
\text { Verz: verz.\& dienstverlenende beroepen } \\
\text { Verz: haarkappen }\end{array}$ & $\begin{array}{r}60 \\
40 \\
20 \\
- \\
45 \\
45 \\
35 \\
40 \\
20 \\
40\end{array}$ & $\begin{array}{r}45 \\
55 \\
- \\
45 \\
45 \\
40 \\
30 \\
45 \\
-\end{array}$ & $\begin{array}{r}50 \\
45 \\
- \\
30 \\
55 \\
40 \\
45 \\
65 \\
35 \\
60\end{array}$ \\
\hline Totaal & 40 & 40 & 45 \\
\hline
\end{tabular}

Bron: ROA (RUBS) 


\section{De instroom van schoolverlaters uit het leerlingwe- zen, 1995-2000}

\subsection{Inleiding}

In de in 1995 door het ROA uitgebrachte studie De arbeidsmarkt naar opleiding en beroep tot 2000 (ROA, 1995a) worden de arbeidsmarktperspectieven voor (K)MBO en leerlingwezen gezamenlijk gepresenteerd. In het vorige hoofdstuk bleek echter dat schoolverlaters van het leerlingwezen een arbeidsmarktpositie hebben die soms sterk afwijkt van de positie van (K)MBO'ers. Dit wordt veroorzaakt doordat het leerlingwezen zich deels op andere beroepen richt dan het MBO en doordat tijdens de opleiding andere kwalificaties meer accent kregen. In dit rapport zullen daarom de prognoses uit ROA (1995a) worden toegespitst op het leerlingwezen. Er doen zich bij deze toespitsing echter een tweetal complicaties voor. Ten eerste worden $\mathrm{KMBO}, \mathrm{MBO}$ en leerlingwezen in de Enquête Beroepsbevolking (EBB) van het CBS - die een belangrijke bron vormt voor de genoemde prognoses - niet van elkaar onderscheiden. Dit betekent dat het niet direct mogelijk is de drie groepen uit elkaar te halen.

Een tweede complicatie is van meer fundamentele aard. Het MBO en het leerlingwezen richten zich - voor zover het dezelfde vakgebieden betreft - vaak niet zozeer op een ander beroepsdomein, maar leiden personen voor eenzelfde domein op een andere wijze op. Dit betekent in principe dat er bij werkgevers niet op zich vraag naar een MBO'er of vraag naar iemand uit het leerlingwezen zal bestaan, maar dat beide in principe in dezelde behoefte kunnen voorzien. Uiteraard is het mogelijk dat een werkgever de voorkeur geeft aan iemand met een bepaalde opleiding. Dit laat echter onverlet dat bij afwezigheid van sollicitanten uit deze opleiding, kandidaten met de andere achtergrond aangenomen zullen worden.

De arbeidsmarktperspectieven voor een opleiding worden verkregen door de vraag naar schoolverlaters met deze opleiding te confronteren met de verwachte arbeidsmarktinstroom van schoolverlaters. De vraag naar schoolverlaters is opgebouwd uit een vraag als gevolg van het ontstaan van nieuwe banen (uitbreidingsvraag) en de vervangingsvraag. De beschreven complicaties hebben met name betrekking op de bepaling van de vraag. In dit hoofdstuk zal echter allereerst worden ingegaan op het verwachte aanbod van schoolverlaters uit het leerlingwezen. Daartoe worden de instroomprognoses uit opleidingen op MBO/LLW niveau uit (ROA, 1995a,b) voor de periode 1995-2000 verbijzonderd voor het leerlingwezen. De opleidingsrichtingen die in dit hoofdstuk gepresenteerd worden zijn de oplei- 
dingsrichtingen zoals die worden onderscheiden in ROA (1995a, b) ${ }^{8}$. Deze opleidingsrichtingen komen niet precies overeen met de opleidingsrichtingen uit hoofdstuk 5 die gebaseerd zijn op de indeling die in RUBS wordt gehanteerd. De cijfers die in dit hoofdstuk en de hierop volgende hoofdstukken worden gepresenteerd hebben betrekking op zowel primaire als voortgezette leerlingwezenopleidingen.

De opbouw van dit hoofdstuk is als volgt. In paragraaf 6.2 wordt de arbeidsmarktinstroom per landelijk orgaan gepresenteerd. Paragraaf 6.3 geeft vervolgens de instroom naar opleidingsrichting MBO/LLW.

\subsection{De arbeidsmarktinstroom van gediplomeerde schoolverlaters per landelijk orgaan}

De arbeidsmarktinstroomprognoses voor het leerlingwezen zijn gebaseerd op de Opgave van het leerlingwezen 1992 van het Ministerie van OC\&W. Op basis van de prognoses per opleidingsrichting is door ROA de arbeidsmarktinstroom per landelijk orgaan bepaald. Tabel 6.1 geeft het aantal gediplomeerde schoolverlaters voor de periode 1990-1994 en het verwachte aantal gediplomeerde schoolverlaters voor de periode 1995-2000 per landelijk orgaan. De totale uitstroom zal de komende jaren fors afnemen vergeleken met voorgaande jaren.

De grootste arbeidsmarktinstroom wordt verwacht vanuit de SOM en de VEV. Vanuit deze organen zal in de periode 1995-2000 naar verwachting respectievelijk ruim 13.000 en ruim 12.000 gediplomeerde schoolverlaters uitstromen hoewel de instroom lager is dan in de afgelopen periode. Ook de uitstroom vanuit de Innovam en SVB is vrij hoog. In de komende vijf jaar zullen ongeveer 9.800 gediplomeerde schoolverlaters van de SVB en 9.300 gediplomeerde schoolverlaters van INNOVAM de opleiding verlaten.

De laagste uitstroom van schoolverlaters wordt verwacht voor de VAS en KOFS. De toekomstige arbeidsmarktinstroom van de VAS bedraagt ongeveer 100 gediplomeerde schoolverlaters en de arbeidsmarktinstroom van KOFS ongeveer 200. De instroom vanuit de SLHV en VOC/BETEX is eveneens laag. Het aantal gediplomeerde schoolverlaters van de SLHV en VOC/BETEX dat in de periode 1995-2000 de arbeidsmarkt betreedt is respectievelijk 800 en 400 .

8. Er wordt geen onderscheid gemaakt tussen KMBO- en MBO-opleidingen. 
Tabel 6.1

Totale arbeidsmarktinstroom schoolverlaters uit het leerlingwezen (primaire en secundaire opleidingen) per orgaan voor de perioden 1990-1995 en 1995-2000

\begin{tabular}{lrr}
\hline & $1990-1995$ & $1995-2000$ \\
\hline & & \\
LOBAS & 6.400 & 6.100 \\
SOBB & 3.000 & 2.800 \\
SVO & 3.200 & 2.900 \\
VOC/BETEX & 900 & 800 \\
VAS & 100 & 100 \\
SH\&M & 3.900 & 3.500 \\
GOC & 3.300 & 3.000 \\
VAPRO & 3.200 & 2.900 \\
SOM & 14.200 & 13.100 \\
VEV & 13.200 & 12.100 \\
VOC-CAR & 2.100 & 1.900 \\
SVB & 10.700 & 9.800 \\
SBW & 1.900 & 1.800 \\
Intechnium & 7.900 & 7.200 \\
SVS & 4.400 & 4.100 \\
INNOVAM & 10.100 & 9.300 \\
SWW/SLW & 2.600 & 2.400 \\
KOF & 200 & 200 \\
SLHV & 400 & 400 \\
SVGB & 1.700 & 1.600 \\
SVK & 7.900 & 7.300 \\
OCH & 8.000 & 7.400 \\
OVD & 6.000 & 5.500 \\
ECABO & 6.000 & 5.500 \\
OVDB & 8.000 & 8.100 \\
& & \\
Totaal & 133.000 & 122.200 \\
inclusief LLW-opleidingen op VBO-niveau & & \\
& & \\
\hline & & \\
\hline
\end{tabular}

Bron: ROA

\subsection{De arbeidsmarktinstroom naar opleidingsrichting}

De arbeidsmarktinstroom van leerlingen naar verschilt sterk per opleidingsrichting. In de richtingen MBO technisch laboratorium, MBO toerisme en recreatie, MBO/LLW commercieel, MBO bestuurlijk juridisch, MBO sociaal cultureel, MBO/LLW uiterlijke verzorging ${ }^{\circ}$ en MBO/LLW politie en defensie komen geen

9. De opleidingen van SVK (kappers) en $\mathrm{OCH}$ (horeca) zijn ingedeeld bij de opleidingsrichting MBO/LLW verzorging. De reden hiervoor is dat volgens de SOl-classificatie van het CBS deze opleidingen ook onder de verzorgende richtingen vallen. De MBO kappers- en horecaopleidingen vallen wel onder MBO/LLW uiterlijke verzorging. Deze inconsistente indeling heeft als gevolg dat de arbeidsmarktperspectieven van LLW- en MBO-schoolverlaters van kappers en horecaopleidingen niet met elkaar vergeleken kunnen worden. 
leerlingwezenopleidingen voor. Deze richtingen zullen in het vervolg buiten beschouwing worden gelaten.

Tabel 6.2

Arbeidsmarktinstroom schoolverlaters uit het leerlingwezen (primaire en secundaire opleidingen) naar opleidingsrichting, 1990-1995 en 1995-2000

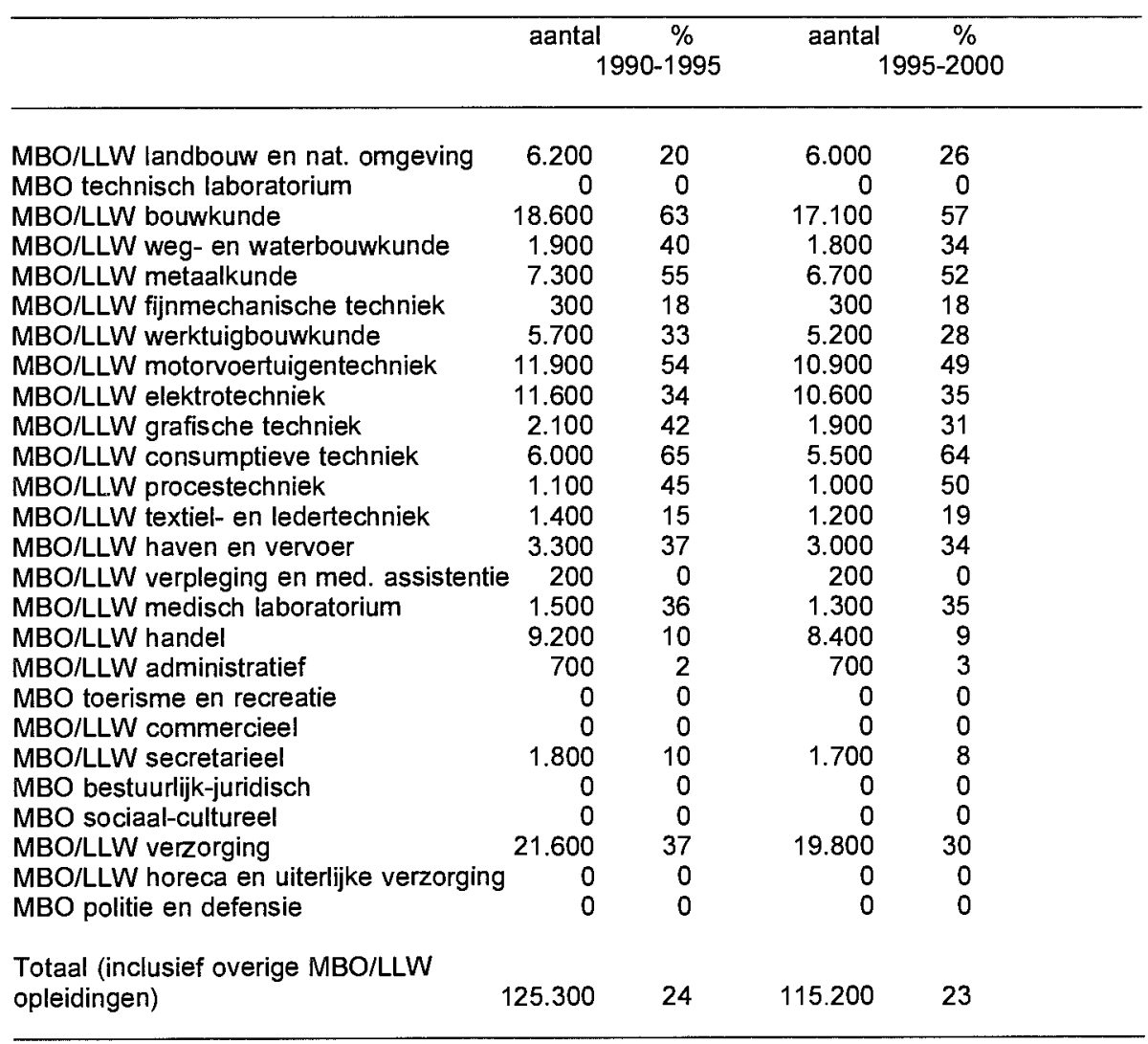

Bron: ROA

* De percentages zijn genomen van de totale arbeidsmarktinstroom voor MBO/LLW

In totaal zal ongeveer $23 \%$ van de schoolverlaters op MBO/LLW-niveau afkomstig zijn uit het leerlingwezen. Het aandeel van het leerlingwezen in de totale arbeidsmarktinstroom op $\mathrm{MBO} / L \mathrm{LW}$-niveau lag in de afgelopen periode overigens iets hoger, namelijk op $24 \%$. Het aandeel van het leerlingwezen in de totale arbeidsmarktinstroom is het grootst voor de opleidingstypen MBO/LLW consumptieve techniek en MBO/LLW bouwkunde. In beide richtingen maken LLW-schoolverlaters meer dan de helft van de totale instroom uit. Het aandeel van het leerlingwezen in de opleidingsrichting MBO/LLW bouwkunde zal overigens wel flink dalen van $63 \%$ in de periode 1990-1994 naar 57\% in de periode 1995-2000. In de richtingen MBO/LLW metaalkunde, MBO/LLW motorvoertuigentechniek en MBO/LLW proces- 
techniek zal ongeveer de helft van de schoolverlaters uit het leerlingwezen komen. In de richting $M B O / L L W$ procestechniek neemt het aandeel van het leerlingwezen toe terwij! in de richtingen MBO/LLW metaalkunde en motorvoertuigentechniek het aandeel juist zal dalen ten opzichte van de afgelopen jaren. Het aandeel van LLWschoolverlaters in de richtingen MBO/LLW verpleging en medische assistentie, $\mathrm{MBO} / \mathrm{LLW}$ handel, MBO/LLW administratief en MBO/LLW secretarieel is zeer gering. $\mathrm{Bij} \mathrm{MBO/LLW} \mathrm{verpleging} \mathrm{en} \mathrm{medische} \mathrm{assistentie} \mathrm{is} \mathrm{er} \mathrm{slechts} \mathrm{één} \mathrm{opleiding}$ die in het leerlingwezen wordt gegeven namelijk de opleiding tot apothekersassistent, de overige opleidingen die onder deze richting vallen bijvoorbeeld opleidingen tot verpleegkundigen worden alleen op het $M B O$ gegeven ${ }^{10}$. Bij de opleidingen MBO/LLW administratief, MBO/LLW secretarieel en MBO/LLW handel valt overigens op dat terwijl de instroom vanuit de organen die deze opleidingen verzorgen (ECABO en OVD) relatief groot is, dit aantal vergeleken met de MBO-instroom in deze richtingen juist erg klein is.

Geconcludeerd kan worden dat het leerlingwezen het grootst aandeel in de technische opleidingen heeft, gevolgd door de verzorgende opleidingen. Het aandeel van het leerlingwezen in economisch/administratieve opleidingen blijkt zeer gering.

10. De in-service-opleidingen worden hier tot het MBO gerekend. 


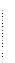




\section{De vraag naar schoolverlaters uit het leerlingwezen}

\subsection{Inleiding}

In dit hoofdstuk worden de vraagprognoses voor MBO/LLW-opleidingen voor de periode 1995-2000 (zie ook ROA, 1995a,b) per opleidingsrichting verbijzonderd naar de vraag naar leerlingwezenschoolverlaters en (K)MBO-schoolverlaters afzonderlijk. De vraagprognoses bestaan uit twee componenten: de uitbreidingsvraag en de vervangingsvraag. De uitbreidingsvraag geeft de ontwikkeling van de werkgelegenheid voor een bepaald opleidingstype. De vervangingsvraag is de vraag die ontstaat als gevolg van (vervroegde) pensionering, tijdelijke uittreding van de arbeidsmarkt, beroepsmobiliteit e.d. Bij een toename van de werkgelegenheid vormen de uitbreidingsvraag en vervangingsvraag tezamen de baanopeningen voor nieuwkomers op de arbeidsmarkt. Om deze baanopeningen op te splitsen naar baanopeningen voor LLW-schoolverlaters en (K)MBO-schoolverlaters, moeten de beroepsdomeinen voor LLWers en (K)MBO'ers in kaart worden gebracht. In paragraaf 7.2 wordt eerst kort ingegaan op de wijze van verbijzonderen van de vraagprognoses. In paragraaf 7.3 zullen de beroepsdomeinen per opleidingstype worden besproken. Vervolgens zal in paragraaf 7.4 het verwachte aantal baanopeningen vanuit deze beroepsdomeinen worden gepresenteerd.

\subsection{Het verbijzonderen van de vraagprognoses}

De uitbreidingsvraagprognoses naar opleidingstype zijn gebaseerd op de uitbreidingsvraag per ROA-beroepssegment ${ }^{11}$. Op basis van de opleidingsstructuur van de beroepen wordt de voorspelde uitbreidingsvraag per beroepssegment vertaald naar een uitbreidingsvraag per opleidingstype. Daarbij wordt ook rekening gehouden met de verwachte veranderingen in de opleidingsstructuur gedurende de prognoseperiode als gevolg van 'upgradingsprocessen'. Om de uitbreidingsvraag per MBO/LLWopleidingsrichting te verbijzonderen naar een afzonderlijke vraag voor (K)MBO'ers en LLWers moet bepaald worden welke beroepssegmenten relevant zijn voor LLWers en welke relevant zijn voor (K)MBO'ers. Er zijn echter geen gegevens beschikbaar over de beroepenstructuur van (K)MBO'ers en LLWers voor de beroepsbevolking als geheel ${ }^{12}$. Wel kan op basis van RUBS bepaald worden hoe de werkgelegenheid van schoolverlaters uit het leerlingwezen en het $(K) M B O$ over de

11. De ROA-beroepssegmentindeling is een indeling op een hoger aggregatie-niveau dan de ROA-beroepsklasseindeling die wordt gebruikt in hoofdstuk 3 .

12. In de EBB worden (K)MBO en leerlingwezen immers niet van elkaar onderscheiden. 
ROA-beroepssegmenten is verdeeld ${ }^{13}$. Een beroepsdomein voor LLWers en (K)MBO'ers wordt dan bepaald door het aandeel van LLWers en (K)MBO'ers in een bepaald beroepssegment te vergelijken. Als het aandeel van LLWers in een beroepssegment naar verhouding veel groter is dan dat van (K)MBO'ers dan behoort dat beroepssegment tot het leerlingwezenberoepsdomein. $\mathrm{Er}$ is dan vanuit dit beroepssegment alleen sprake van vraag naar mensen met een leerlingwezenopleiding. Er zullen echter ook beroepssegmenten zijn die niet duidelijk alleen voor LLWers of alleen voor (K)MBO'ers relevant zijn. Dat is dan het gezamenlijke beroepsdomein van (K)MBO'ers en LLWers. De beroepssegmenten kunnen daarom in drie categorieën worden verdeeld: beroepen die alleen relevant zijn voor het leerlingwezen ( $L L W$-domein), beroepen die alleen relevant zijn voor het (K)MBO (MBO-domein) en beroepen die zowel relevant zijn voor het LLW als het (K)MBO (MBO/LLW-domein).

De ROA-prognoses met betrekking tot de vraag per beroepssegment hebben echter betrekking op alle werkenden met een bepaalde opleidingsachtergrond. De verdeling van deze groep wijkt af van de verdeling van alleen de schoolverlaters over de beroepssegmenten. Er zijn immers beroepen waarin men niet direct gaat werken na het verlaten van de opleiding, maar die wel relevant zijn voor leerlingwezen- of MBO-schoolverlaters in de loop van hun carrière. Dat geldt met name voor enkele middelbare en hogere beroepssegmenten, in het bijzonder enkele leidinggevende functies. Uitbreidingsvraag in deze beroepen voor een (K)MBO- of leerlingwezenopleiding betekent niet automatisch dat een schoolverlater in deze beroepen gaat werken. Het kan ook betekenen dat een (K)MBO'er of LLWer die zich al langer op de arbeidsmarkt bevindt promotie maakt en zo ruimte maakt voor een schoolverlater in een beroepssegment waar schoolverlaters wel direct kunnen gaan werken. $\mathrm{Er}$ kan dus sprake zijn van een keten van vacatures waarvan alleen de laatste door een schoolverlater wordt bezet.

Als de uitbreidingsvraag voor (K)MBO'ers en LLWers dus uitsluitend wordt bepaald op basis van beroepssegmenten waarin schoolverlaters werkzaam zijn wordt een deel van de uitbreidingsvraag ten onrechte niet meegenomen. Dit probleem kan worden opgelost door bij het bepalen van het totaal aantal baanopeningen per opleiding (dat is de som van de positieve uitbreidingsvraag en de vervangingsvraag) ook rekening te houden met vervangingsvraag als gevolg van baan-baanmobiliteit. Als er sprake is van uitbreidingsvraag voor een bepaalde opleiding in een beroep

13. Omdat de steekproef onder LLW-schoolverlaters niet representatief is moet de beroepenstructuur voor LLW'ers bepaald worden op basis van personen die op het moment van enquête een leerlingwezenopleiding volgden. De veronderstelling is dat de relevante beroepssegmenten na afloop van de opleiding gelijk zijn aan de beroepssegmenten waarin men gedurende de opleiding werkzaam was. Zie ook appendix $C$. 
waarin schoolverlaters niet kunnen starten dan wordt deze vraag niet opgevuld door een schoolverlater met deze opleiding maar door iemand die al langer werkzaam is. Er ontstaat dan een vacature in het beroep waar deze 'doorstromer' voorheen werkzaam was. Als deze vacature weer zou worden opgevuld door iemand met dezelfde opleidingsachtergrond dan is er sprake van een vervangingsvraag naar deze opleiding vanuit het betreffende beroep. De uitbreidingsvraag vanuit een beroep waarin schoolverlaters niet kunnen starten leidt daarom tot een vervangingsvraag in beroepen waarin schoolverlaters wel kunnen starten.

Natuurlijk zijn er ook beroepen waarin zowel schoolverlaters kunnen gaan werken als mensen die al zich al langer op de arbeidsmarkt bevinden. Van belang is op te merken dat vanwege de invalshoek beroep, een deel van de vraag gezien wordt als vervangingsvraag, dat vanuit de invalshoek opleiding als uitbreidingsvraag zou worden aangemerkt. Het gaat echter alleen om een herschikking, zodat het totaal aantal baanopeningen gelijk blijft. Appendix $C$ gaat dieper in op de technische aspecten van het verbijzonderen van de ROA-arbeidsmarktprognoses.

\subsection{Het beroepsdomein van MBO- en LLW-schoolverlaters}

In hoofdstuk 5 werden al aanwijzingen gevonden dat (K)MBO'ers een wijder beroepsdomein hebben dan LLWers. Zij hebben meer uitwijkmogelijkheden naar andere beroepen. Ook lijkt het dat algemene vaardigheden van groter belang zijn in beroepen waar (K)MBO'ers werken dan in beroepen waar LLWers werken. Dat duidt er op dat (K)MBO'ers ook vaker in niet vakspecifieke functies werkzaam zijn dan LLWers.

Per opleidingsrichting MBO/LLW is op basis van de schoolverlatersenquête RUBS een afzonderlijk domein voor (K)MBO'ers (MBO-domein) en LLWers ( $L L W$-domein) bepaald. Daarnaast wordt een gemeenschappelijk beroepsdomein onderscheiden ( $M B O / L L$-domein) (zie ook appendix C). Het domein geldt voor zowel primaire als voortgezette leerlingwezenopleidingen. Bedacht moet worden dat onder veel opleidingsrichtingen meer (K)MBO-opleidingen vallen dan LLW-opleidingen. Dat leidt mogelijk tot een groter beroepsdomein voor $(K)$ MBO'ers. De tabellen met de beroepsdomeinen staan weergegeven in appendix $D$.

\section{MBO/LLW landbouw en natuurlijke omgeving}

Bij de opleidingsrichting $M B O / L L W$ landbouw en natuurlijk omgeving zijn geen beroepssegmenten gevonden die alleen relevant zijn voor het leerlingwezen. Wel zijn er beroepen die voornamelijk van belang zijn voor (K)MBO-schoolverlaters. Het blijkt dat het hier voor een groot deel inderdaad gaat om enkele bredere functies zoals de middelbare technische-, ambachts- en industrieberoepen en de middelbare 
administratieve functies. Tot deze beroepen worden onder andere ondernemers, uitvoerders en bedrijfskundigen gerekend ${ }^{14}$. De werkgelegenheid in deze beroepen zal naar verwachting de komende jaren flink toenemen.

Opmerkelijk is dat de hogere medische en paramedische beroepen tot het beroepsdomein behoren van (K)MBO-schoolverlaters uit de richting landbouw en natuurlijke omgeving. Het blijkt hier te gaan om biologische laboranten.

Beroepen die zowel relevant zijn voor schoolverlaters met een leerlingwezenopleiding als schoolverlaters met een (K)MBO-opleiding zijn de meer vakspecifieke beroepen zoals de lager agranische beroepen en de middelbare kunst- en vormgevende beroepen (voornamelijk bloemschikken). De werkgelegenheid in de lagere agranische beroepen zal overigens de komende vijf jaren naar verwachting gaan afnemen.

\section{MBO/LLW bouwkunde}

Ook in de richting bouwkunde blijken (K)MBO-schoolverlaters vaker in meer bredere functies werkzaam te zijn dan mensen met een leerlingwezenopleiding. Het gaat ook bij deze opleidingsrichting met name om de middelbare technische-, ambachts en industrieberoepen en de middelbare administratieve beroepen. Verder blijkt dat (K)MBO'ers ook in middelbare bouw- en installatieberoepen werkzaam zijn, terwijl mensen met een leerlingwezenopleiding voornamelijk in lager technische beroepen werken, zoals de lagere bouw- en installatieberoepen. De werkgelegenheid in beide beroepssegmenten zal in de toekomst naar verwachting gaan dalen. Het leerlingwezen heeft in deze richting niet een specifiek eigen beroepsdomein.

\section{MBO/LLW weg- en waterbouwkunde}

In de richting weg-en waterbouwkunde werken (K)MBO-schoolverlaters meer in de middelbare beroepen zoals de middelbare technische ambachts- en industrieberoepen en de middelbare bouw- en installatieberoepen. De lagere technische ambachts- en industrieberoepen zijn alleen relevant voor mensen met een leerlingwezenopleiding. Deze beroepen zullen de komende jaren naar verwachting licht groeien. Tot de lagere technische ambachts- en industrieberoepen worden gere-

14. Hier speelt mogelijk overigens wel dat het beroepsdomein voor LLWers is bepaald op basis van de werkgelegenheidsverdeling van mensen die de opleiding volgen en niet op basis van de werkgelegenheidsverdeling van schoolverlaters uit het leerlingwezen. Voor enkele richtingen is daarom ook naar schoolverlaters uit het leerlingwezen gekeken en het blijkt dat ook dan deze beroepen niet tot het beroepsdomein van LLW'ers kunnen worden gerekend. 
kend heftruckrijders en machinisten bouw en industrie. De krimpende lagere bouwen installatieberoepen zijn zowel voor het $(\mathrm{K}) \mathrm{MBO}$ als het leerlingwezen van belang.

\section{MBO/LLW metaalkunde}

Omdat in RUBS geen goed onderscheid gemaakt kan worden tussen de opleidingen MBO/LLW metaalkunde, MBO/LLW fijnmechanische techniek en MBO/LLW werktuigbouwkunde zijn deze opleidingen samen genomen bij het bepalen van de beroepsdomeinen. Omdat de uiteindelijke selectie van beroepen ook op basis van de EBB, waarin deze opleidingen uiteraard wel kunnen worden onderscheiden, gemaakt is, verschillen de domeinen toch iets tussen de genoemde opleidingsrichtingen (zie ook appendix D).

Ook voor de richting metaalkunde geldt dat (K)MBO'ers vaker in niet vakspecifieke beroepen werkzaam zijn. Verder geldt dat er geen specifiek eigen beroepsdomein voor mensen met een leerlingwezenopleiding is. De middelbare metaalberoepen behoren tot het domein van (K)MBO-schoolverlaters, terwijl de lager metaalberoepen tot het gezamenlijke domein behoren. De werkgelegenheid zal voor zowel de lagere als de middelbare metaalberoepen krimpen. Hetzelfde patroon bleek ook al op te gaan bij de opleidingsrichting weg- en waterbouwkunde voor de bouw-en installatieberoepen. Verder zijn ook de middelbare elektrotechnische en de lagere bouw- en installatieberoepen voor zowel (K)MBO- als leerlingwezenschoolverlaters van belang. Terwijl de werkgelegenheid in de middelbare elektrotechnische beroepen min of meer constant blijft zal de werkgelegenheid in de lagere bouwberoepen naar verwachting dalen. Ook de werkgelegenheid in de lagere metaalberoepen en de middelbare metaalberoepen zal de komende jaren dalen.

\section{$M B O / L L W$ fijnmechanische techniek}

Het leerlingwezen heeft in de richting fijnmechanische techniek geen specifiek eigen beroepsdomein. Tot het beroepsdomein voor MBO'ers en KMBO'ers in deze richting behoren de lagere en middelbare commerciële beroepen en de middelbare administratieve beroepen. De commerciële beroepen zullen de komende jaren een flinke groei doormaken terwijl de werkgelegenheid in de middelbare administratieve beroepen juist zal dalen.

Tot het gezamenlijke beroepsdomein behoren de krimpende lagere en middelbare metaalberoepen. Opvallend is ook dat de middelbare technisch, ambachts en industrieberoepen tot het gezamenlijke domein kunnen worden gerekend. 
$M B O / L L W$ werktuigbouwkunde

Ook (K)MBO'ers uit de richting werktuigbouwkunde hebben een vrij groot beroepsdomein. Naast enkele technische beroepen zoals de middelbare technische, ambachts- en industrieberoepen en de middelbare metaalberoepen behoren ook enkele niet technische beroepen zoals de middelbare administratieve en de lagere commerciële beroepen tot het $\mathrm{MBO}$-domein. Het leerlingwezen heeft in deze richting geen eigen domein. Tot het MBO/LLW-domein behoren de lagere metaalberoepen, de middelbare elektrotechnische beroepen en de lagere bouw- en installatieberoepen. Dat zijn allemaal technische beroepen waarvan de werkgelegenheid naar verwachting zal dalen.

\section{MBO/LLW motorvoertuigentechniek}

Bij de richting motorvoertuigentechniek geldt eveneens dat het leerlingwezen in tegenstelling tot het (K)MBO, geen specifiek eigen domein van betekenis heeft. Tot het specifiek MBO-domein behoren niet vaktechnische beroepen zoals de midde/bare administratieve beroepen en de lagere commerciële beroepen. In de eerstgenoemde beroepen zal de werkgelegenheid naar verwachting dalen in de laatstgenoemde beroepen zal de werkgelegenheid daartentegen juist toenemen. Tot het gezamenlijke domein behoren de krimpende lagere en middelbare metaalberoepen.

\section{MBO/LLW elektrotechniek}

Personen met een leerlingwezenopleiding in de richting elektrotechniek hebben in tegenstelling tot veel leerlingwezenopleidingen in de andere technische richtingen wel een specifiek eigen beroepsdomein. De licht groeiende lagere elektrotechnische beroepen zijn alleen relevant voor het leerlingwezen. De constant blijvende middelbare elektrotechnische beroepen zijn daarentegen zowel voor het leerlingwezen als het (K)MBO van belang. Tot het specifieke beroepsdomein van het (K)MBO behoren de middelbare technische ambachts- en industrieberoepen, de lagere metaalberoepen en de lagere commerciële beroepen. Terwijl de werkgelegenheid in de middelbare technische ambachts- en industrieberoepen en de lagere commerciële beroepen flink zal groeien neemt de werkgelegenheid in de metaalberoepen naar verwachting af.

\section{MBO/LLW grafische techniek}

In de richting grafische techniek behoren de lagere grafische beroepen en de middelbare kunst- en vormgevende beroepen tot het gezamenlijke beroepsdomein van het (K)MBO en het LLW. In beide beroepssegmenten zal de werkgelegenheid 
de komende jaren naar verwachting toenemen. Het beroepsdomein van (K)MBO'ers in deze richting omvat een groot aantal beroepen, waaronder ook een aantal nietvakspecifieke beroepen zoals de middelbare commerciële beroepen, de middelbare technische ambachts- en industrieberoepen en de middelbare administratieve beroepen. Het leerlingwezen heeft ook in deze richting geen specifiek eigen beroepsdomein.

$M B O / L L W$ consumptieve techniek

In de richting consumptieve techniek heeft het leerlingwezen wel een eigen beroepsdomein. Zowel de lagere voedings- en genotmiddelenberoepen als de lagere commerciële beroepen behoren tot het LLW-domein. De werkgelegenheid in de lagere voedings- en genotmiddelenberoepen zal zoals opgemerkt de komende jaren overigens sterk afnemen. Opvallend is dat het (K)MBO in deze richting geen eigen beroepsdomein van enige betekenis heeft. De sterk groeiende middelbare medische en paramedische beroepen behoren tot het gezamenlijke beroepsdomein.

\section{MBO/LLW procestechniek}

Voor mensen met een leerlingwezenopleiding in de richting procestechniek zijn met name de lagere hout- en papierberoepen relevant. Dat zijn beroepen met een krimpende werkgelegenheid. De lagere chemische en de lagere elektrotechnische beroepen zijn voor zowel het (K)MBO als het leerlingwezen van belang. Het MBOdomein bevat alleen de lagere metaalberoepen.

\section{MBO/LLW textiel- en ledertechniek}

De lagere textielberoepen en de lagere commerciële beroepen behoren tot het gezamenlijke beroepsdomein van (K)MBO'ers en LLWers in de opleidingsrichting textiel- en ledertechniek. De lagere textielberoepen zullen in de toekomst een grote werkgelegenheidsdaling doormaken. Het MBO-domein is vrij divers en omvat onder andere de groeiende middelbare kunst- en vormgevende beroepen en de krimpende middelbare administratieve beroepen. Ook de lagere verzorgende beroepen (schoonmaakpersoneel) behoren tot dit domein. Het lijkt hier echter te gaan om uitwijksegmenten. Het beroepsdomein van het leerlingwezen is zo klein dat de beroepen in dit domein niet onderscheiden kunnen worden.

\section{$M B O / L L W$ haven en vervoer}

Bij de opleidingsrichting haven en vervoer vormen de naar verwachting groeiende lagere rail- en wegtransportberoepen het LLW-domein. De groeiende lagere transportberoepen en krimpende lagere manitieme en andere waterwegtransportberoepen 
horen tot het MBO/LLW-beroepsdomein, terwijl de middelbare maritieme en andere waterwegtransportberoepen alleen van belang zijn voor mensen met een (K)MBO opleiding in de richting haven en vervoer. De werkgelegenheid in de middelbare maritieme en andere waterwegtransportberoepen zal naar verwachting toenemen. Opvallend is overigens dat het (K)MBO en het LLW in deze opleidingsrichting een vrij groot gezamenlijk beroepsdomein hebben. Beroepen die zowel relevant zijn voor het leerlingwezen als voor het (K)MBO zijn onder andere nog de krimpende lagere metaalberoepen en de middelbare metaalberoepen. Ook de middelbare administratieve beroepen zijn zowel voor het leerlingwezen als voor het (K)MBO relevant.

MBO/LLW verpleging en medische assistentie

Alleen de middelbare medische en paramedische beroepen zijn relevant voor deze opleidingsrichting. Deze beroepen zijn echter niet relevant voor het leerlingwezen. Dat komt omdat er in RUBS geen schoolverlaters voorkomen die een leerlingwezenopleiding volgen in deze richting. Er bestaan echter wel leerlingwezenopleidingen voor deze richting. De voortgezette opleiding voor apothekersassistent van de OVDB zou hier onder moeten vallen. Er kan voor deze opleidingsrichting dus geen vergelijking worden gemaakt tussen (K)MBO- en LLW-schoolverlaters. Deze opleidingsrichting zal daarom verder buiten beschouwing worden gelaten.

\section{MBO/LLW medisch laboratorium}

Tot het specifiek beroepsdomein van het leerlingwezen in deze richting horen de krimpende lagere metaalberoepen (bijvoorbeeld instrumentenmakers) en de groeiende middelbare medische en paramedische beroepen (onder andere opticiens). Tot het gezamenlijke beroepsdomein kunnen de hogere medische en paramedische beroepen worden gerekend. Naar verwachting zal de werkgelegenheid in deze beroepen de komende tijd flink toenemen. Middelbare technische ambachts en industrieberoepen (naast ondememers omvatten deze beroepen ook technische en medische vertegenwoordigers en laboranten) en middelbare administratieve beroepen zijn alleen van belang voor (K)MBO-schoolverlaters.

\section{MBO/LLW handel}

$\mathrm{Er}$ is geen eigen beroepsdomein voor het leerlingwezen in deze opleidingsrichting. De lagere commerciële beroepen behoren tot het gezamenlijke beroepsdomein van (K)MBO en leerlingwezen terwijl de middelbare commerciële beroepen tot het

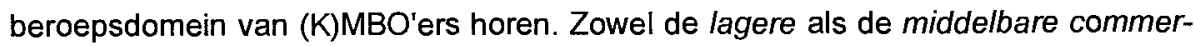
ciële beroepen zullen naar verwachting groeien. Verder kunnen ook de lagere transportberoepen en de middelbare administratieve beroepen tot het gezamenlijke beroepsdomein worden gerekend. Voor (K)MBO'ers in deze richting zijn verder van 
belang de lagere horecaberoepen, de lagere administratieve beroepen en de lagere rail- en wegtransportberoepen.

\section{MBO/LLW administratief en MBO/LLW secretanieel}

De opleidingsrichtingen MBO/LLW administratief en secretarieel kunnen in RUBS niet apart worden onderscheiden voor de leerlingwezenopleidingen. Daarom zijn deze opleidingsrichtingen samengenomen bij het bepalen van de beroepenstructuur ${ }^{15}$.

Opvallend is dat bij de opleidingsrichtingen MBO/LLW administratief de hogere administratieve beroepen alleen relevant zijn voor het leerlingwezen. Het gaat hier om systeemanalisten. De werkgelegenheid voor systeemanalisten zal in de toekomst naar verwachting fors toenemen. De naar verwachting krimpende lagere en middelbare administratieve beroepen en de groeiende lagere commerciële beroepen worden tot het gezamenlijke beroepsdomein gerekend. De lagere transportberoepen, en de middelbare commerciële beroepen vallen in het MBO-domein.

Bij de opleiding MBO/LLW secretarieel is er alleen een gezamenlijk beroepsdomein voor (K)MBO'ers en LLW'ers. Tot dit gezamenlijke domein behoren de middelbare administratieve beroepen.

\section{$M B O / L L W$ verzorging}

In de richting verzorging zijn het (K)MBO en het leerlingwezen wat moeilijker te vergelijken omdat de horecaopleidingen en de kappersopleidingen op LLW-niveau tot deze opleidingsrichting worden gerekend. Dezelfde opleidingen op (K)MBOniveau worden echter tot de richting MBO/LLW uiterlijke verzorging en horeca gerekend. Dat verklaart tevens waarom de lagere horecaberoepen en de middelbare verzorgende beroepen (kappers en schoonheidsspecialisten) hier tot het LLWdomein behoren. Naar verwachting zal de werkgelegenheid in de lagere horecaberoepen de komende jaren toenemen maar zal de werkgelegenheid in de middelbare verzorgende beroepen afnemen. Tot het MBO-beroepsdomein behoren de naar verwachting groeiende middelbare medische en paramedische beroepen, de lagere commerciële beroepen en de hogere sociaal-culturele beroepen. De lagere verzorgende beroepen vallen onder het gezamenlijke beroepsdomein.

15. Omdat de uiteindelijke selectie van het beroepsdomein ook op basis van de EBB is gebeurd verschillen de domeinen toch enigszins (zie appendix D). 
Het blijkt dat in het algemeen het beroepsdomein van (K)MBO-schoolverlaters inderdaad groter is dan het beroepsdomein van het leerlingwezen. Verder behoren niet-vaktechnische beroepen zoals commerciële of administratieve beroepen vaak tot het MBO-domein en zelden tot het LLW-domein. Tevens lijkt het erop dat er in het LLW-domein, en het MBO/LLW domein vaker krimpende beroepen voorkomen. De tendenzen op de arbeidsmarkt zijn in de meeste richtingen dusdanig dat de vraag naar vakspecifieke functies vermindert, ten koste van meer algemene beroepen. Deze ontwikkeling werkt in het nadeel van het leerlingwezen.

\subsection{Baanopeningen voor MBO en LLW verbijzonderd naar beroepsdomein}

Op basis van de voorspelde groei per beroepssegment en rekening houdend met de veranderende opleidingsstructuur in de prognoseperiode kan nu de uitbreidingsvraag naar schoolverlaters met een (K)MBO- of LLW-opleiding worden verbijzonderd naar een vraag per beroepsdomein. Het gaat hier, zoals gezegd, om beroepsdomeinen voor schoolverlaters. Een deel van de uitbreidingsvraag kan niet verbijzonderd worden, omdat de verdeling van LLW'ers en (K)MBO'ers over beroepen waar men niet direct gaat werken niet bekend is. De uitbreidingsvraag vanuit deze beroepen wordt dus buiten beschouwing gelaten. Daar wordt echter voor gecompenseerd door de hogere vervangingsvraag als gevolg van baan-baanmobiliteit.

Tabel 7.1 geeft de uitbreidingsvraag per opleidingrichting vanuit achtereenvolgens het LLW-domein, het MBO-domein en het MBO/LLW domein. In de vorige paragraaf bleek al dat bij de meeste opleidingsrichtingen LLW'ers geen specifiek eigen beroepsdomein hebben. Daarom is er bij veel opleidingsrichtingen geen specifieke vraag voor het leerlingwezen. Echter ook bij veel opleidingen waar het leerlingwezen wel een eigen beroepsdomein heeft is er geen uitbreidingvraag vanuit dat domein. Dat geldt bijvoorbeeld voor de opleidingsrichtingen MBO/LLW procestechniek en MBO/LLW verzorging.

Specifieke leerlingwezenberoepen blijken vaak een ongunstige werkgelegenheidsontwikkeling te hebben. Dat geldt bijvoorbeeld sterk voor de middelbare verzorgende beroepen. Deze beroepen vallen bij de opleiding MBO/LLW verzorgend onder het domein van het leerlingwezen. Voor deze beroepen wordt in de komende jaren een werkgelegenheidsdaling van gemiddeld $2,3 \%$ per jaar verwacht ${ }^{16}$.

16. Een dalende werkgelegenheid van beroepen in het beroepsdomein leidt overigens niet per definitie tot een negatieve uitbreidingsvraag vanuit dat domein omdat er ook sprake kan zijn van verschuivingen in de gevraagde opleidingsachtergrond. 
Ook de uitbreidingsvraag vanuit het gezamelijke beroepsdomein is absoluut gezien vrij laag. De absoluut grootste uitbreidingsvraag doet zich bij de meeste opleidingsrichtingen voor in het MBO-beroepsdomein. Dat geldt met name bij de opleidingsrichting MBO/LLW handel.

Tabel 7.1

Uitbreidingsvraag naar opleidingsrichting, $1995-2000^{*}$

\begin{tabular}{|c|c|c|c|c|c|c|}
\hline & \multicolumn{2}{|c|}{$\begin{array}{l}\text { LLW-domein } \\
\text { aantal \% }\end{array}$} & \multicolumn{2}{|c|}{$\begin{array}{l}\text { MBO-domein } \\
\text { aantal } \%\end{array}$} & \multicolumn{2}{|c|}{$\begin{array}{l}\text { MBO/LLW-domein } \\
\text { aantal } \%\end{array}$} \\
\hline MBO/LLW landbouw en natuurlijke omgeving & $\mathrm{ng}$ & - & 0 & 0 & -2.100 & -2 \\
\hline MBO/LLW bouwkunde & - & & 3.900 & 8 & 100 & 0 \\
\hline MBO/LLW weg-en waterbouwkunde & 200 & 11 & 700 & 7 & 0 & 0 \\
\hline MBO/LLW metaalkunde & - & - & 1.300 & 9 & 500 & 1 \\
\hline MBO/LLW fijnmechanische techniek & - & - & 600 & 9 & 400 & 4 \\
\hline MBO/LLW werktuigbouwkunde & - & & 3.000 & 9 & 400 & 1 \\
\hline MBO/LLW motorvoertuigentechniek & - & - & 600 & 7 & 0 & 0 \\
\hline MBO/LLW elektrotechniek & 300 & 10 & 3.400 & 8 & 1.200 & 2 \\
\hline MBO/LLW grafische techniek & - & - & 1.000 & 8 & 900 & 5 \\
\hline MBO/LLW consumptieve techniek & 800 & 3 & 300 & 10 & 0 & 2 \\
\hline MBO/LLW procestechniek & 0 & 0 & 200 & 6 & 400 & 5 \\
\hline MBO/LLW textiel- en ledertechniek & 100 & 9 & 200 & 2 & 800 & 7 \\
\hline MBO/LLW haven en vervoer & 900 & 9 & 700 & 6 & 500 & 3 \\
\hline MBO/LLW medisch laboratorium & 1.800 & 10 & 300 & 9 & 400 & 14 \\
\hline MBO/LLW handel & & & 13.600 & 9 & 8.400 & 5 \\
\hline MBO/LLW administratief & 1.700 & 25 & 400 & 7 & 0 & 0 \\
\hline MBO/LLW secretarieel & - & - & - & - & 0 & 0 \\
\hline MBO/LLW verzorging & 0 & 0 & 5.200 & 10 & 1.500 & 2 \\
\hline
\end{tabular}

Bron: ROA

De percentages zijn genomen van de totale werkgelegenheid van MBO'ers en LLW'ers in het betreffende beroepsdomein volgens de EBB (gehele beroepsbevolking)

Toch zijn er enkele opleidingsrichtingen waarbij de uitbreidingsvraag in het LLWdomein wel vrij hoog is. Dat geldt bijvoorbeeld voor de opleidingsrichtingen MBO/LLW administratief, MBO/LLW weg- en waterbouwkunde, MBO/LLW medische laboratorium en MBO/LLW elektrotechniek. De opleidingsrichtingen met de grootste relatieve uitbreidingsvraag in het MBO-beroepsdomein zijn $\mathrm{MBO} / L L W$ verzorging en MBO/LLW consumptieve techniek. Verder is er voor de richting MBO/LLW medisch laboratorium een relatief grote uitbreidingsvraag in het MBO/LLW-domein.

Tabel 7.2 geeft de vervangingsvraag per opleidingsrichting en per beroepsdomein. De absoluut hoogste vervangingvraag vanuit het LLW-domein is te vinden bij de opleidingsrichting MBO/LLW verzorging. Ook bij de richtingen MBO/LLW consumptieve techniek en MBO/LLW medisch laboratorium is sprake van een redelijk grote absolute vervangingsvraag in het LLW-domein. De vervangingsvraag vanuit het MBO-domein is, absoluut gezien, in de meeste richtingen groter dan in de andere beroepsdomeinen. Vooral in de richtingen MBO/LLW handel en MBO/LLW verzor- 
ging is sprake van een hoge absolute vervangingsvraag in het MBO-beroepsdomein. $\mathrm{Er}$ is bij enkele richtingen eveneens sprake van een hoge vervangingsvraag vanuit het gezamenlijke beroepsdomein. Dat geldt onder andere voor de richtingen MBO/LLW handel en MBO/LLW bouwkunde.

Tabel 7.2

Vervangingsvraag naar opleidingsrichting, $1995-2000^{\circ}$

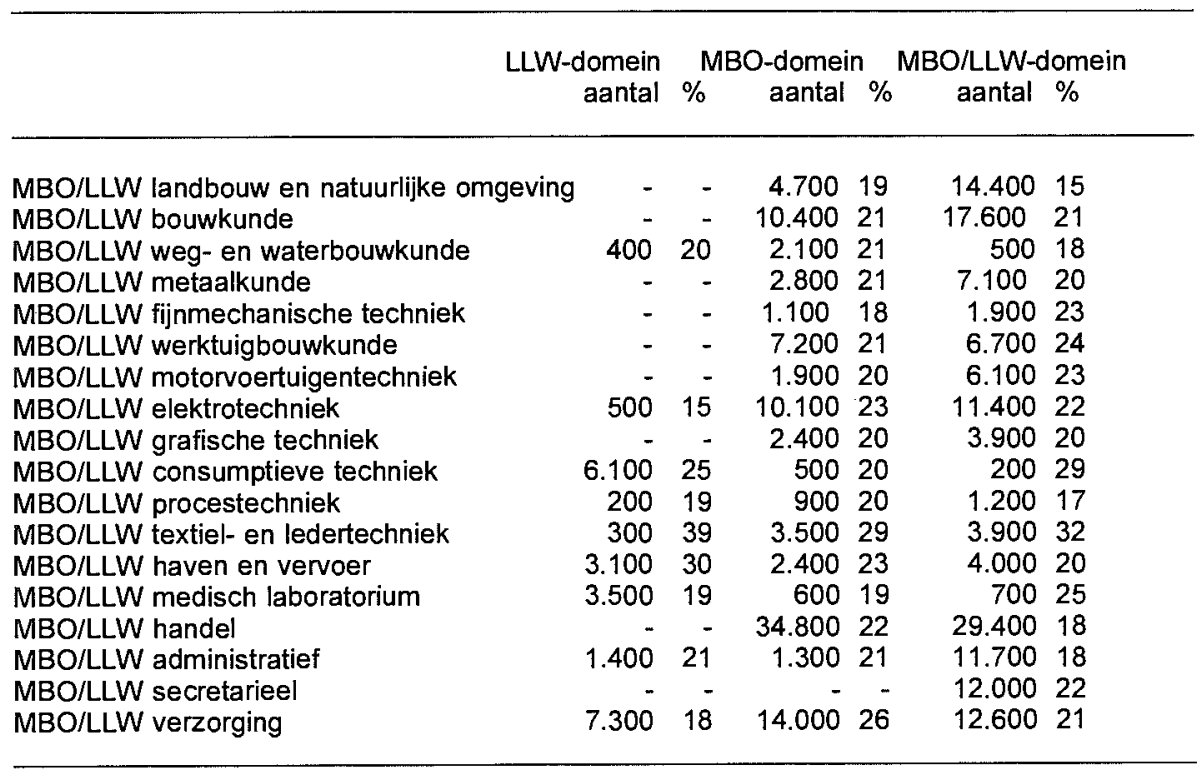

Bron: ROA

De percentages zijn genomen van de totale werkgelegenheid van MBO'ers en LLW'ers in het betreffende beroepsdomein volgens de EBB (gehele beroepsbevolking)

De relatief hoogste vervangingsvraag vanuit het LLW-domein komt voor bij de opleidingsrichtingen MBO/LLW haven en vervoer, MBO/LLW textiel- en ledertechniek en MBO/LLW grafische techniek. Bij de twee laatst genoemde richtingen is de vervangingsvraag overigens absoluut gezien erg klein. Verder is de vervangingsvraag in het MBO-domein relatief hoog bij de opleidingsrichting MBO/LLW elektrotechniek. De vervangingsvraag vanuit het gezamenlijke beroepsdomein is relatief hoog bij de richtingen MBO/LLW medisch laboratorium en MBO/LLW werktuigbouwkunde.

Het totaal van de vervangingsvraag en de (positieve) uitbreidingvraag geeft het aantal baanopeningen per richting en per beroepsdomein. Tabel 7.3 geeft het aantal baanopeningen per opleidingsrichting en domein. Tabel 7.4 geeft daarnaast het aandeel van elk domein in het totaal aantal baanopeningen per opleidingsrichting. 
Tabel 7.3

Baanopeningen naar opleidingsrichting, $1995-2000^{*}$

\begin{tabular}{|c|c|c|c|c|c|c|}
\hline \multirow{2}{*}{\multicolumn{2}{|c|}{ MBO/LLW landbouw en natuurlijke omgeving }} & $\begin{array}{l}\text { LLW-domein } \\
\text { aantal } \%\end{array}$ & \multicolumn{3}{|c|}{$\begin{array}{l}\text { MBO-domein } \\
\text { aantal \% }\end{array}$} & $\begin{array}{l}\text { MBO/LLW-domein } \\
\text { aantal } \%\end{array}$ \\
\hline & & - & 4.700 & 19 & 14.400 & 15 \\
\hline MBO/LLW bouwkunde & 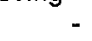 & - & 14.200 & 29 & 17.700 & 21 \\
\hline MBO/LLW weg- en waterbouwkunde & 600 & 31 & 2.800 & 28 & 500 & 18 \\
\hline MBO/LLW metaalkunde & - & - & 4.100 & 30 & 7.600 & 22 \\
\hline MBO/LLW fijnmechanische techniek & - & - & 1.700 & 27 & 2.300 & 28 \\
\hline MBO/LLW werktuigbouwkunde & - & - & 10.200 & 29 & 7.100 & 25 \\
\hline MBO/LLW motorvoertuigentechniek & - & - & 2.600 & 27 & 6.100 & 23 \\
\hline MBO/LLW elektrotechniek & 900 & 25 & 13.500 & 30 & 12.600 & 24 \\
\hline MBO/LLW grafische techniek & & & 3.400 & 28 & 4.800 & 24 \\
\hline MBO/LLW consumptieve techniek & 6.900 & 28 & 800 & 29 & 200 & 31 \\
\hline MBO/LLW procestechniek & 200 & 19 & 1.100 & 26 & 1.500 & 23 \\
\hline MBO/LLW textiel- en ledertechniek & 400 & 48 & 3.700 & 31 & 4.800 & 39 \\
\hline MBO/LLW haven en vervoer & 4.000 & 39 & 3.000 & 29 & 4.500 & 22 \\
\hline MBO/LLW medisch laboratorium & 5.300 & 29 & 900 & 28 & 1.100 & 38 \\
\hline MBO/LLW handel & - & - & 48.300 & 31 & 37.700 & 23 \\
\hline MBO/LLW administratief & 3.100 & 46 & 1.700 & 28 & 11.700 & 18 \\
\hline MBO/LLW secretarieel & - & - & - & - & 12.000 & 22 \\
\hline MBO/LLW verzorging & 7.300 & 18 & 19.200 & 36 & 14.100 & 24 \\
\hline
\end{tabular}

Bron: ROA

De percentages zijn genomen van de totale werkgelegenheid van MBO'ers en LLW'ers in het betreffende beroepsdomein volgens de EBB (gehele beroepsbevolking)

Tabel 7.4

Aandeel baanopeningen per domein naar opleidingsrichting

\begin{tabular}{|c|c|c|c|}
\hline LLW-dor & & $\begin{array}{r}\text { MBO-domein } \\
\%\end{array}$ & $\begin{array}{r}\text { MBO/LLW-domein } \\
\%\end{array}$ \\
\hline MBO/LLW landbouw en natuurlijke omgeving & - & 25 & 75 \\
\hline MBO/LLW bouwkunde & - & 44 & 55 \\
\hline MBO/LLW weg-en waterbouwkunde & 15 & 72 & 13 \\
\hline MBO/LLW metaalkunde & - & 35 & 65 \\
\hline MBO/LLW fijnmechanische techniek & - & 42 & 57 \\
\hline MBO/LLW werktuigbouwkunde & - & 59 & 41 \\
\hline MBO/LLW motorvoertuigentechniek & - & 29 & 70 \\
\hline MBO/LLW elektrotechniek & 3 & 50 & 47 \\
\hline MBO/LLW grafische techniek & - & 41 & 58 \\
\hline MBO/LLW consumptieve techniek & 87 & 10 & 3 \\
\hline MBO/LLW procestechniek & 7 & 40 & 53 \\
\hline MBO/LLW textiel- en ledertechniek & 5 & 41 & 54 \\
\hline MBO/LLW haven en vervoer & 35 & 26 & 39 \\
\hline MBO/LLW medisch laboratorium & 72 & 13 & 15 \\
\hline MBO/LLW handel & - & 56 & 44 \\
\hline MBO/LLW administratief & 19 & 11 & 71 \\
\hline MBO/LLW secretarieel & - & - & 100 \\
\hline MBO/LLW verzorging & 18 & 47 & 35 \\
\hline
\end{tabular}

Bron: ROA 
Het blijkt dat het aantal baanopeningen in het LLW-domein in de meeste opleidingsrichtingen ver achter blijft bij het aantal baanopeningen in het $\mathrm{MBO}$ - en het MBO/LLW-domein. Er zijn echter enkele uitzonderingen. Bij de opleidingsrichting MBO/LLW consumptieve techniek komt ongeveer $87 \%$ van het totaal aantal baanopeningen uit het LLW-domein, 10\% uit het MBO-domein en 3\% uit het MBO/LLW-domein. Ook in de richting MBO/LLW medische laboratorium is het aandeel van het LLW-domein in het totaal aantal baanopeningen erg groot, ruim $70 \%$. Bij MBO/LLW secretarieel zijn er alleen baanopeningen in het gezamenlijke beroepsdomein. In de richting MBO/LLW weg- en waterbouwkunde komt ruimt $70 \%$ van het totaal aantal baanopeningen uit het MBO-domein. Andere richtingen waar een groot deel van het totaal aantal baanopeningen uit het (K)MBO-domein afkomstig is, zijn MBO/LLW werktuigbouwkunde en MBO/LLW handel. Bij de richtingen MBO/LLW metaalkunde, MBO/LLW motorvoertuigentechniek en MBO/LLW administratief is het aandeel van het gezamenlijke domein in het totaal aantal baanopeningen vrij groot.

$\mathrm{Bij}$ de meeste opleidingsrichtingen is de vraag vanuit het MBO- en het MBO/LLWdomein het grootst. De vraag vanuit het MBO/LLW-domein betreft een vraag voor zowel (K)MBO'ers als LLWers. In het volgende hoofdstuk zal worden bekeken hoe deze vraag wordt verdeeld over schoolverlaters uit het (K)MBO en het leerlingwezen. 


\section{Confrontatie van vraag en aanbod}

\subsection{Inleiding}

In de vorige twee hoofdstukken werd achtereenvolgens ingegegaan op aanbod en vraag voor (K)MBO en leerlingwezen. In dit hoofdstuk wordt de instroom vanuit het leerlingwezen en het (K)MBO geconfronteerd met de vraag. Om vraag en aanbod voor het (K)MBO en het leerlingwezen elk afzonderlijk te kunnen confronteren moet de vraag die voor zowel het leerlingwezen als het $(\mathrm{K}) \mathrm{MBO}$ bestemd is, dus de vraag vanuit het gezamenlijke beroepsdomein verdeeld worden. Zoals reeds eerder werd aangegeven lijkt het niet zinvol te veronderstellen dat er in dit domein sprake is van een afzonderlijke vraag naar (K)MBO'ers en een afzonderlijke vraag naar LLW'ers. Beide opleidingen richten zich immers in principe op dezelfde kwalificaties, maar verschilen juist in de wijze waarop deze kwalificaties tot stand komen. $\mathrm{Er}$ is dus eerder sprake van vraag voor (K)MBO of leerlingwezen, hoewel werkgevers uiteraard hun voorkeur kunnen hebben. Er moeten daarom veronderstellingen worden gemaakt over deze voorkeuren van werkgevers. Er zal een drietal scenario's worden uitgewerkt die elk uitgaan van andere veronderstellingen over het selectiegedrag van werkgevers. In paragraaf 8.2 zullen deze scenario's worden besproken. In paragraaf 8.3 zal worden ingegaan op de arbeidsmarktperspectieven voor LLW'ers en (K)MBO'ers onder de verschillende scenario's.

\subsection{De vraag vanuit het gezamenlijke beroepsdomein}

De vraag per opleidingsrichting MBO/LLW is in hoofdstuk 7 opgesplitst naar een vraag voor (K)MBO'ers, een vraag voor LLWers en een vraag voor zowel (K)MBO'ers als LLW'ers. Bij de laatstgenoemde gaat het om de vraag vanuit het gezamenlijke beroepsdomein van het (K)MBO en het leerlingwezen. Om deze vraag te confronteren met het aanbod moeten veronderstellingen worden gemaakt over de voorkeuren van werkgevers. Het gaat dan wel om een vraag vanuit beroepen waar in principe zowel (K)MBO als LLW-schoolverlaters kunnen gaan werken, maar het is bijvoorbeeld mogelijk dat werkgevers een sterke voorkeur hebben voor (K)MBO'ers. In dat geval neemt een werkgever alleen een LLW-schoolverlater aan als hij geen (K)MBO-schoolverlater kan krijgen. Aan de andere kant is het ook mogelijk dat werkgevers juist een voorkeur hebben voor schoolverlaters uit het leerlingwezen. Een andere mogelijkheid is dat werkgevers geen onderscheid maken tussen LLW'ers en (K)MBO'ers. In dat geval hebben (K)MBO- en LLW-schoolverlaters gelijke kansen bij vraag vanuit het gezamenlijke beroepsdomein.

De voorkeuren van werkgevers voor (K)MBO- of LLW-schoolverlaters zullen verschillen per opleidingsrichting. In hoofdstuk 5 bleek al dat de arbeidsmarktpositie 
van (K)MBO'ers op sommige punten nogal verschilt van de arbeidsmarktpositie van schoolverlaters uit het leerlingwezen. Zo is de werkloosheid onder leerlingwezenschoolverlaters in de meeste opleidingsrichtingen beduidend lager dan de werkloosheid onder (K)MBO-schoolverlaters. Dat heeft voor een deel te maken met het feit dat veel leerlingwezenschoolverlaters na het verlaten van de opleiding bij het leerbedrijf kunnen blijven werken. Bovendien krijgen veel leerlingen bij de aanvang van de opleiding al een vaste baan aangeboden. In dat geval is er bij werkgevers indirect sprake van een voorkeur voor leerlingwezenschoolverlaters. Leerlingwezenschoolverlaters hoeven dan niet te concurreren met (K)MBO-schoolverlaters, omdat ze al verzekerd zijn van een baan.

In hoofdstuk 4 bleek dat met name leerlingwezenschoolverlaters uit enkele technische richtingen vaak bij het verlaten van de opleiding nog bij hetzelfde bedrijf werkzaam bleven. Uitschieters waren schoolverlaters van de organen GOC en Intechnium. Vooral voor schoolverlaters uit de richtingen MBO/LLW grafische techniek en MBO/LLW bouwkunde is een voorkeur van werkgevers voor leerlingwezenschoolverlaters daarom een vrij plausibele veronderstelling. Er zijn echter meerdere organen die opleidingen in de richting bouwkunde verzorgen. Het is niet bekend of schoolverlaters van de andere organen die op de bouw gericht zijn na het voltooien van de opleiding ook bij het leerbedrijf blijven werken. Schoolverlaters van de VEV en SOM blijven wat minder vaak dan gemiddeld bij hetzelfde bedrijf werken. Voor schoolverlaters uit de richtingen MBO/LLW elektrotechniek en MBO/LLW metaaltechniek zijn er daarom minder aanwijzingen dat werkgevers een voorkeur hebben voor leerlingwezenschoolverlaters. Toch is ook hier deze veronderstelling niet implausibel omdat toch een deel van de schoolverlaters bij hetzelfde bedrijf blijft werken. Voor de andere technische richtingen zijn geen gegevens over leerlingwezenschoolverlaters beschikbaar.

Voor de richting MBO/LLW handel is een voorkeur voor leerlingwezenschoolverlaters eveneens een redelijk scenario omdat leerlingwezenschoolverlaters uit deze richting ook relatief vaak nog bij hetzelfde bedrijf blijven werken. Dat geldt ook voor LLW-schoolverlaters uit de richting MBO/LLW verzorgend, hoewel de aanwijzingen hier wat minder sterk zijn.

Leerlingwezenschoolverlaters uit de economische administratieve richtingen blijven echter veel minder vaak bij het leerbedrijf werken na het voltooien van de opleiding. Voor de opleidingsrichtingen MBO/LLW administratief en secretarieel is een voorkeur van werkgevers voor schoolverlaters uit het leerlingwezen daarom niet zo voor de hand liggend. Er zijn voor deze opleidingsrichtingen eerder aanwijzingen voor een voorkeur voor (K)MBO-schoolverlaters. Voorbeelden daarvan zijn de slechtere aansluiting tussen de opleiding op het huidige beroep voor schoolverlaters uit het leerlingwezen en een veel hoger percentage onderbenutting. 
De arbeidsmarktperspectieven van (K)MBO'ers en LLW'ers afzonderlijk hangt in sterke mate af van de voorkeur die werkgevers hebben als ze kunnen kiezen tussen beide opleidingsgroepen. De mogelijke consequenties van het selectiegedrag zijn uitgewerkt in een drietal scenario's. In het eerste scenario hebben werkgevers een voorkeur voor (K)MBO'ers. Dat betekent dat de totale vraag vanuit het gezamenlijke domein een vraag voor (K)MBO'ers is. De totale vraag naar (K)MBO'ers is dan de som van de vraag vanuit het (K)MBO-domein en de vraag vanuit het gezamenlijke domein. Er wordt verondersteld dat er alleen vraag naar mensen met een leerlingwezenopleiding vanuit het gezamenlijke beroepsdomein is, als het aanbod van (K)MBO'ers op dit domein tekort schiet. De totale vraag naar mensen met een leerlingwezenopleiding is gelijk aan de som van de vraag vanuit het LLW-domein en de onvervulde vraag uit het MBO/LLW-domein. Daarbij wordt overigens steeds verondersteld dat (K)MBO'ers en mensen met een leerlingwezenopleiding een voorkeur hebben voor beroepen in hun eigen beroepsdomein en zich pas aanbieden voor banen buiten dit domein als de vraag in hun eigen domein ontoereikend is.

Volgens het tweede scenario zijn werkgevers indifferent tussen (K)MBO- en LLWschoolverlaters. (K)MBO-schoolverlaters en LLW-schoolverlaters hebben daarom gelijke kansen op het gezamenlijke domein. De vraag naar LLW-schoolverlaters vanuit het gezamenlijke domein is dan afhankelijk van zowel het (K)MBO- als het LLW-aanbod op dit domein.

In het derde scenario hebben werkgevers een voorkeur voor schoolverlaters uit het leerlingwezen. Dit is het meeste gunstige scenario voor leerlingwezenschoolverlaters. De totale vraag voor leerlingwezenschoolverlaters is dan de som van de vraag uit het LLW-domein en de vraag uit het gezamenlijke domein. De vraag voor (K)MBO'ers is de vraag vanuit het (K)MBO-domein en het positieve verschil van de vraag vanuit het gezamenlijke domein en het aanbod van mensen met een leerlingwezenopleiding op dit domein.

Uiteraard zullen in de praktijk de voorkeuren van werkgevers minder uitgesproken liggen dan in deze drie scenario's wordt aangenomen. De drie gevallen duiden dan ook als het ware op het interval waarbinnen het arbeidsmarktperspectief van de schoolverlaters zal liggen. Informatie over de relatieve positie van LLWers en (K)MBO'ers, zoals die in hoofdstuk 5 werd gepresenteerd, geeft aanwijzigingen over de positie die de opleiding feitelijk inneemt binnen dit interval. 


\subsection{Arbeidsmarktperspectieven voor LLW'ers en MBO'ers volgens drie scena- rio's}

Alvorens de arbeidsmarktperspectieven volgens de drie scenario's voor (K)MBO en leerlingwezen afzonderlijk worden besproken, zal kort worden ingegaan op de arbeidsmarktperspectieven voor (K)MBO en LLW te zamen, zoals deze beschreven zijn in De arbeidsmarkt naar Opleiding en Beroep tot 2000 (ROA, 1995a,b). Tabel 8.1 geeft de arbeidsmarktperspectieven per MBO/LLW-opleidingsrichting. Er zijn een aantal technisch opleidingen met redelijke tot goede arbeidsmarktperspectieven. Dat zijn MBO/LLW fijnmechanische techniek, MBO/LLW grafische techniek, MBO/LLW textiel- en ledertechniek, MBO/LLW bouwkunde en MBO/LLW procestechniek. Voor de overige technische opleidingen zijn de perspectieven matig tot slecht. Dat lijkt ongunstig voor het leerlingwezen omdat het leerlingwezen zich vooral richt op technische opleidingen. Verder hebben de opleidingen MBO/LLW medisch laboratorium en MBO/LLW haven en vervoer goede perspectieven. Goede of slechte perspectieven voor het (K)MBO en leerlingwezen tezamen duiden echter niet per definitie op goede of slechte perspectieven voor het (K)MBO en leerlingwezen afzonderlijk. Het is immers mogelijk dat de werkgelegenheid in de afzonderlijke beroepsdomeinen van het $(\mathrm{K}) \mathrm{MBO}$ en leerlingwezen zich verschillend ontwikkelt.

Tabel 8.1

Indicator toekomstige arbeidsmarktsituatie (ITA) naar opleiding in 2000

\begin{tabular}{lll}
\hline Opleidingstype & ITA & $\begin{array}{l}\text { typering } \\
\text { arbeidsmarktsituatie }\end{array}$ \\
\hline MBO/LLW landbouw en natuurlijke omgeving & 1,11 & matig \\
MBO/LLW bouwkunde & 1,03 & redelijk \\
MBO/LLW weg- en waterbouwkunde & 1,07 & matig \\
MBO/LLW metaalkunde & 1,07 & matig \\
MBO/LLW fijnmechanische techniek & 0,93 & goed \\
MBO/LLW werktuigbouwkunde & 1,06 & matig \\
MBO/LLW motorvoertuigentechniek & 1,22 & slecht \\
MBO/LLW elektrotechniek & 1,06 & matig \\
MBO/LLW grafische techniek & 0,99 & goed \\
MBO/LLW consumptieve techniek & 1,06 & matig \\
MBO/LLW procestechniek & 1,03 & redelijk \\
MBO/LLW textiel- en ledertechniek & 1,00 & goed \\
MBO/LLW haven en vervoer & 0,98 & goed \\
MBO/LLW medisch laboratorium & 0,94 & goed \\
MBO/LLW handel & 1,05 & redelijk \\
MBO/LLW administratief & 1,12 & matig \\
MBO/LLW secretarieel & 1,11 & matig \\
MBO/LLW verzorging & 1,14 & matig \\
\hline
\end{tabular}

Bron: ROA (1995, b) 
De arbeidsmarktperspectieven voor (K)MBO'ers en LLW'ers volgens de verschillende scenario's die in deze paragraaf zullen worden gepresenteerd, zijn overigens niet direct te vergelijken met de Indicator Toekomstig Arbeidsmarktperspectief (ITA) uit tabel 8.1. Ten eerste zijn de arbeidsmarktperspectieven die hier worden gepresenteerd iets anders gedefinieerd namelijk als de verhouding tussen de instroom en de vraag. Bij de ITA wordt de omvang van de werkzame beroepsbevolking verdisconteerd in de indicator. Aangezien deze cijfers niet bekend zijn voor het (K)MBO en leerlingwezen afzonderlijk is dat hier niet het geval. Verder is bij de instroom geen rekening gehouden met extra instroom als gevolg van het aanschaffen van de dienstplicht. De kortdurende werkloosheid is eveneens niet meegenomen. Uitgaande van een kortdurende werkloosheid onder (K)MBO'ers en LLWers van $6 \%$ duidt een indicator met een waarde kleiner dan 0,94 op goede arbeidsmarktperspectieven. Tenslotte is hier ook geen rekening gehouden met de substitutievraag. De indicatoren die worden gepresenteerd zijn daarom vooral van belang om de arbeidsmarktperspectieven van (K)MBO'ers en LLWers onderling te vergelijken.

Tabe/ 8.2

Arbeidsmarktindicator als werkgevers een voorkeur voor MBO'ers hebben

\begin{tabular}{|c|c|c|c|c|}
\hline & indicator & $\begin{array}{l}\text { LLW } \\
\text { typering }\end{array}$ & indicator & $\begin{array}{l}\mathrm{MBO} \\
\text { typering }\end{array}$ \\
\hline MBO/LLW landbouw en natuurlijke omgeving & 2,83 & slecht & 0,89 & goed \\
\hline MBO/LLW bouwkunde & 0,96 & redelijk & 0,40 & goed \\
\hline MBO/LLW weg-en waterbouwkunde & 3,02 & slecht & 1,05 & redelijk \\
\hline MBO/LLW metaalkunde & 1,22 & matig & 0,53 & goed \\
\hline MBO/LLW fijnmechanische techniek & 0,13 & goed & 0,35 & goed \\
\hline MBO/LLW werktuigbouwkunde & 1,48 & matig & 0,80 & goed \\
\hline MBO/LLW motorvoertuigentechniek & $\infty$ & slecht & 1,29 & matig \\
\hline MBO/LLW elektrotechniek & 1,45 & matig & 0,75 & goed \\
\hline MBO/LLW grafische techniek & 0,47 & goed & 0,52 & goed \\
\hline MBO/LLW consumptieve techniek & 0,80 & goed & 2,99 & slecht \\
\hline MBO/LLW procestechniek & 0,57 & goed & 0,37 & goed \\
\hline MBO/LLW textiel- en ledertechniek & 0,35 & goed & 0,63 & goed \\
\hline MBO/LLW haven en vervoer & 0,54 & goed & 0,79 & goed \\
\hline MBO/LLW medisch laboratorium & 0,25 & goed & 1,21 & matig \\
\hline MBO/LLW handel & 2,12 & slecht & 0,95 & redelijk \\
\hline MBO/LLW administratief & 0,22 & goed & 1,95 & matig \\
\hline MBO/LLW secretarieel & $\infty$ & slecht & 1,61 & matig \\
\hline MBO/LLW verzorging & 2,73 & slecht & 1,37 & matig \\
\hline
\end{tabular}

Bron: ROA

Tabel 8.2 geeft de arbeidsmarktperspectieven voor (K)MBO- en LLW-schoolverlaters als werkgevers een voorkeur hebben voor (K)MBO-schoolverlaters. Dit is het meest negatieve scenario voor schoolverlaters uit het leerlingwezen. Als het leerlingwezen in een bepaalde opleidingsrichting dan toch een goed perspectief heeft dan kan gesteld worden dat het leerlingwezen in deze richting goede arbeids- 
marktperspectieven heeft, ongeacht de voorkeuren van werkgevers. Dat zal voornamelijk het geval zijn als de vraag vanuit het LLW-domein groot is, als de arbeidsmarktinstroom van LLW-schoolverlaters klein is of als de arbeidsmarktinstroom van (K)MBO-schoolverlaters relatief klein is.

Voor de richting MBO/LLW fijnmechanische techniek geldt dat zowel de instroom van (K)MBO- als LLW-schoolverlaters relatief klein is. De Instroom van het (K)MBO schiet tekort om aan de totale vraag vanuit het (K)MBO-domein te voldoen, zodat de vraag naar LLW-schoolverlaters gelijk is aan de totale vraag vanuit het gezamenlijke domein. Daarom heeft het leerlingwezen in deze richting goede arbeidsmarktperspectieven. Ook bij de opleiding MBO/LLW grafische techniek heeft het leerlingwezen evenals het (K)MBO een goed perspectief. De vraag vanuit het gezamenlijke domein is zo groot dat ook als werkgevers de voorkeur aan (K)MBO'ers geven er nog genoeg banen voor LLW-schoolverlaters overblijven. In de richting consumptieve techniek heeft het leerlingwezen een goed perspectief en het (K)MBO een slecht perspectief. De meeste vraag komt hier vanuit het LLW-domein. Bij de richting MBO/LLW procestechniek verschilt het arbeidsmarktperspectief voor LLW'ers niet zoveel van dat van (K)MBO'ers. Ook bij de opleidingsrichting MBO/LLW textiel- en ledertechniek hebben zowel het (K)MBO als het leerlingwezen een goed arbeidsmarktperspectief. De instroom vanuit het leerlingwezen is klein ten opzichte van de (K)MBO-instroom, terwijl de vraag uit het gezamenlijk beroepsdomein vrij groot is. Leerlingwezenschoolverlaters uit de richting MBO/LLW haven en vervoer hebben zelfs een beter perspectief dan (K)MBO-schoolverlaters. De vraag vanuit het LLW-domein is in deze richting relatief groot.

Bij opleidingsrichtingen MBO/LLW medisch laboratorium en MBO/LLW administratief hebben leerlingwezenschoolverlaters in dit scenario eveneens een beter perspectief dan (K)MBO-schoolverlaters. Bij MBO/LLW medisch laboratorium wordt dat veroorzaakt door een grote vraag vanuit het LLW-domein. De betere perspectieven voor MBO/LLW schoolverlaters in de richting MBO/LLW administratief komen voort uit de relatieve kleine instroom van leerlingwezenschoolverlaters van nog geen $3 \%$ van de totale arbeidsmarktinstroom.

Richtingen waarbij in dit scenario de perspectieven voor het leerlingwezen in verhouding tot het (K)MBO vrij slecht zijn, zijn MBO/LLW landbouw en natuurlijke omgeving, MBO/LLW weg- en waterbouwkunde, MBO/LLW metaalkunde, MBO/LLW werktuigbouwkunde, MBO/LLW motorvoertuigentechniek, MBO/LLW elektrotechniek, MBO/LLW handel en MBO/LLW secretarieel. Bij de meeste van deze richtingen heeft het leerlingwezen geen eigen beroepsdomein.

Uit tabel 8.3 blijkt dat als (K)MBO'ers en LLW'ers gelijke kansen hebben het perspectief voor LLW-schoolverlaters in deze richtingen verbetert. $\mathrm{Bij}$ al deze 
richtingen blijft het perspectief voor LLW-schoolverlaters echter slechter dan het perspectief voor (K)MBO'ers. In de meeste richtingen is er voor (K)MBO'ers immers sprake van een vraag uit het (K)MBO-domein terwijl LLW'ers vaak geen specifiek eigen beroepsdomein hebben. Bij de opleidingsrichting MBO/LLW secretarieel hebben (K)MBO'ers en LLW'ers exact gelijke perspectieven. Dat komt omdat in deze richting alleen sprake is van vraag vanuit het gezamenlijke beroepsdomein. Bij gelijke kansen voor het (K)MBO en het leerlingwezen leidt dat tot gelijke arbeidsmarktperspectieven.

Tabel 8.3

Arbeidsmarktindicator als werkgevers geen voorkeur hebben

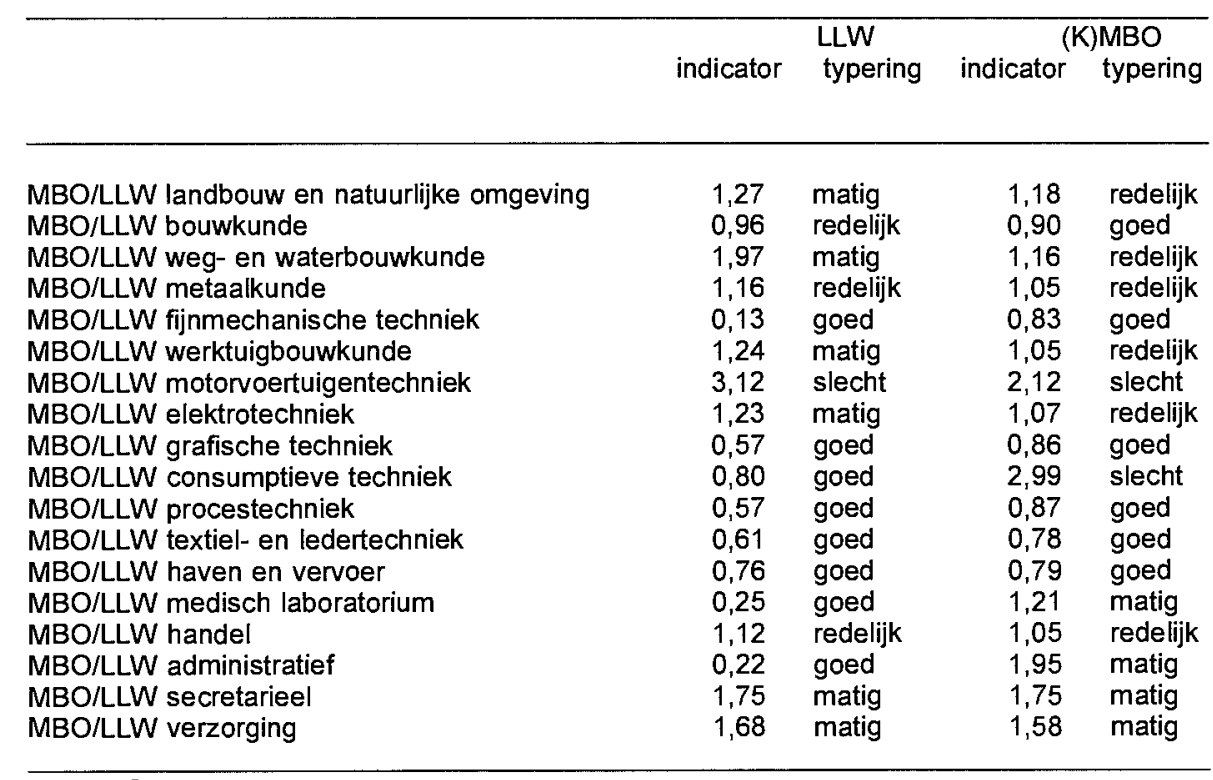

Bron: ROA

Tabel 8.4 laat zien dat als werkgevers een voorkeur zouden hebben voor LLWschoolverlaters boven (K)MBO-schoolverlaters de perspectieven voor schoolverlaters uit het leerlingwezen bij bijna alle opleidingsrichtingen beter zijn dan de perspectieven voor (K)MBO-schoolverlaters. Alleen de perspectieven voor leerlingwezenschoolverlaters uit de richting MBO/LLW weg- en waterbouwkunde zijn ook in dit scenario slechter dan die van (K)MBO'ers. Dat komt doordat bijna de gehele vraag naar schoolverlaters uit deze richting zich in het MBO-domein concentreert. Voor LLW-schoolverlaters uit de richting motorvoertuigentechniek verbetert het perspectief wel ten opzichte van dat van (K)MBO'ers, maar blijft het perspectief matig. 
Tabel 8.4

Arbeidsmarktindicator als werkgevers een voorkeur voor LLW'ers hebben

\begin{tabular}{|c|c|c|c|c|}
\hline & indicator & $\begin{array}{l}\text { LLW } \\
\text { typering }\end{array}$ & indicator & $\begin{array}{l}\text { MBO } \\
\text { typering }\end{array}$ \\
\hline MBO/LLW landbouw en natuurlijke omgeving & 0,41 & goed & 1,29 & matig \\
\hline MBO/LLW bouwkunde & 0,96 & redelijk & 0,85 & goed \\
\hline MBO/LLW weg- en waterbouwkunde & 1,66 & matig & 1,24 & matig \\
\hline MBO/LLW metaalkunde & 0,87 & goed & 1,24 & matig \\
\hline MBO/LLW fijnmechanische techniek & 0,13 & goed & 0,38 & goed \\
\hline MBO/LLW werktuigbouwkunde & 0,74 & goed & 1,14 & redelijk \\
\hline MBO/LLW motorvoertuigentechniek & 1,76 & matig & 4,36 & slecht \\
\hline MBO/LLW elektrotechniek & 0,79 & goed & 1,20 & redelijk \\
\hline MBO/LLW grafische techniek & 0,38 & goed & 0,66 & goed \\
\hline MBO/LLW consumptieve techniek & 0,78 & goed & 3,76 & slecht \\
\hline MBO/LLW procestechniek & 0,57 & goed & 0,53 & goed \\
\hline MBO/LLW textiel- en ledertechniek & 0,24 & goed & 0,70 & goed \\
\hline MBO/LLW haven en vervoer & 0,36 & goed & 0,79 & goed \\
\hline MBO/LLW medisch laboratorium & 0,21 & goed & 2,69 & slecht \\
\hline MBO/LLW handel & 0,22 & goed & 1,06 & redelijk \\
\hline MBO/LLW administratief & 0,05 & goed & 1,95 & matig \\
\hline MBO/LLW secretarieel & 0,14 & goed & 1,87 & matig \\
\hline MBO/LLW verzorging & 0,93 & goed & 2,37 & slecht \\
\hline
\end{tabular}

Bron: ROA

Tabel 8.5 geeft een overzicht van arbeidsmarktperspectieven voor het leerlingwezen en het (K)MBO op basis van de verschillende scenario's. Als het leerlingwezen of het $(\mathrm{K}) \mathrm{MBO}$ in een bepaalde opleidingsrichting in al deze scenario's een goed of redelijk perspectief heeft dan kan met zekerheid worden gezegd dat het leerlingwezen of het $(K) M B O$ in die richting redelijk tot goede perspectieven heeft. Als de perspectieven sterk verschillen in de onderscheiden scenario's dan is het niet mogelijk om met een redelijke zekerheid het arbeidsmarktperspectief van de betreffende leerlingwezen- of (K)MBO-opleiding te typeren. Wel kan bij sommige van deze opleidingen worden aangegeven welke scenario het meest plausibel is.

Het arbeidsmarktperspectief voor het leerlingwezen in de richting MBO/LLW landbouw en natuurlijke omgeving is alleen goed als werkgevers altijd een voorkeur voor LLW-schoolverlaters zouden hebben. Er is echter a priori geen reden om te veronderstellen dat werkgevers de voorkeur geven aan LLW-schoolverlaters. Het is daarom niet mogelijk om betrouwbare uitspraken te doen over de positie van het leerlingwezen in deze richting.

Het leerlingwezen heeft in de richting bouwkunde in alle scenario's een redelijk perspectief. Voor het $(\mathrm{K}) \mathrm{MBO}$ in deze richting zijn de perspectieven daarentegen in alle scenario's goed. In de richting weg- en waterbouwkunde heeft het leerlingwezen in alle scenario's een matig tot slecht arbeidsmarktperspectief terwijl het 
(K)MBO een redelijk tot matig perspectief heeft. Het arbeidsmarktperspectief voor LLW-schoolverlaters in de richting metaalkunde is goed als werkgevers een voorkeur hebben voor LLW-schoolverlaters boven (K)MBO-schoolverlaters. Een voorkeur van werkgevers voor LLW-schoolverlaters is bij deze opleidingsrichting niet onwaarschijnlijk.

Tabel 8.5

Arbeidsmarktperspectieven voor het leerlingwezen en (K)MBO in $2000^{\circ}$

LLW $\quad$ (K)MBO

\begin{tabular}{lll} 
MBO/LLW landbouw en natuurlijke omgeving & - & - \\
MBO/LLW bouwkunde & redelijk & goed \\
MBO/LLW weg- en waterbouwkunde & matig/slecht & redelijk/matig \\
MBO/LLW metaalkunde & - & - \\
MBO/LLW fijnmechanische techniek & goed & goed \\
MBO/LLW werktuigbouwkunde & - & redelijk/goed \\
MBO/LLW motorvoertuigentechniek & matig/slecht & matig/slecht \\
MBO/LLW elektrotechniek & - & redelijk/goed \\
MBO/LLW grafische techniek & goed & goed \\
MBO/LLW consumptieve techniek & goed & slecht \\
MBO/LLW procestechniek & goed & goed \\
MBO/LLW textiel- en ledertechniek & goed & goed \\
MBO/LLW haven en vervoer & goed & goed \\
MBO/LLW medisch laboratorium & goed & matig/slecht \\
MBO/LLW handel & - & redelijk \\
MBO/LLW administratief & goed & matig \\
MBO/LLW secretarieel & - & matig \\
MBO/LLW verzorging & - & matig/slecht \\
\hline Bron: ROA & & \\
'-' = geen typering mogelijk omdat de arbeidsmarktperspectieven & te & sterk verschillen \\
tussen de scenario's. & &
\end{tabular}

Zowel het leerlingwezen als het (K)MBO hebben in de richting fijnmechanische techniek onder alle scenario's goede arbeidsmarktperspectieven. Bij de richting MBO/LLW werktuigbouwkunde verschillen de perspectieven voor het leerlingwezen tussen de scenario's. Alleen als werkgevers een voorkeur hebben voor LLWschoolverlaters dan is het arbeidsmarktperspectief voor het leerlingwezen goed. Dit scenario is redelijk plausibel voor LLW-schoolverlaters uit de richting werktuigbouwkunde omdat tenminste een gedeelte van schoolverlaters van de SOM bij het leerbedrijf in dienst blijft na het voltooien van de opleiding. Het (K)MBO heeft in deze richting redelijk tot goede perspectieven.

Voor zowel (K)MBO-schoolverlaters als LLW-schoolverlaters uit de richting motorvoertuigentechniek geldt dat hun arbeidsmarktperspectieven onder alle scenario's matig tot slecht zijn. LLW-schoolverlaters uit de richting elektrotechniek hebben 
alleen dan goede perspectieven als werkgevers een voorkeur hebben voor LLWschoolverlaters. Anders zijn de perspectieven voor het leerlingwezen in deze richting matig. Ook hier geldt dat voor een deel van de LLW-schoolverlaters uit deze richting deze veronderstelling met betrekking tot de voorkeuren van werkgevers redelijk plausibel is. De perspectieven voor het (K)MBO zijn in deze richting redelijk tot goed.

De opleidingsrichting grafische techniek doet het goed. Het leerlingwezen en het (K)MBO hebben in deze richting beiden onder alle scenario's een goed perspectief. Dat geldt niet voor de opleidingsrichting MBO/LLW consumptieve techniek. Terwij! het perspectief voor het (K)MBO slecht is, is het perspectief voor het LLW juist goed. In de richting procestechniek zijn de perspectieven voor zowel het leerlingwezen als het (K)MBO onder alle scenario's goed. Dat geldt eveneens voor de opleidingsrichtingen MBO/LLW haven en vervoer en MBO/LLW textiel- en ledertechniek. Bij de opleidingsrichtingen MBO/LLW medisch laboratorium en MBO/LLW administratief heeft alleen het leerlingwezen goede perspectieven terwijl de perspectieven voor het $(\mathrm{K}) \mathrm{MBO}$ in de richting administratief matig zijn en in de richting medisch laboratorium zelfs matig tot slecht. Bij MBO/LLW handel, MBO/LLW secretarieel en MBO/LLW verzorging is daarentegen alleen sprake van goede arbeidsmarktperspectieven voor het leerlingwezen als er sprake is van een voorkeur voor LLW-schoolverlaters. Alleen voor de opleidingsrichtingen MBO/LLW handel en MBO/LLW verzorging is een voorkeur voor LLW-schoolverlaters een redelijke veronderstelling. (K)MBO'ers hebben in de genoemde richtingen matig of slechte perspectieven 


\section{Conclusies}

Het leerlingwezen is een onderwijsvorm die een belangrijke bijdrage kan leveren aan een adequate scholing voor leerlingen die zich meer aangesproken voelen door een werksituatie dan door voltijds dagonderwijs. Ten einde het niveau van ongediplomeerden, VBO'ers en MAVO'ers op het door de overheid nagestreefde startkwalificatieniveau te brengen kan deze onderwijsvorm een belangrijke taak vervullen. Voor het succes van het leerlingwezen is het echter van belang dat leerlingen worden opgeleid voor beroepen waar in de toekomst vraag naar is en dat - binnen de werkzaamheden die een leerling bij zijn leerbedrijf verricht - voldoende plaats wordt gevonden voor de opleidingscomponent. In dit rapport werd daarom onderzocht welke ontwikkelingen de arbeidsmarkt in voor het leerlingwezen relevante beroepsdomeinen zal doormaken en welke positie het leerlingwezen hierbij, met name in vergelijking met het (K)MBO, inneemt. In dit hoofdstuk worden de belangrijkste conclusies nogmaals op een rij gezet. Allereerst volgen enkele algemene bevindingen over de positie van het leerlingwezen. Daarna wordt per landelijk orgaan een kort overzicht gegeven van de belangrijkste resultaten van het onderzoek.

Vanwege het duale leersysteem bevindt het leerlingwezen zich in een geheel andere situatie met betrekking tot de aansluiting onderwijs-arbeidsmarkt dan het voltijdse dagonderwijs, zoals het MBO en KMBO. Doordat de leer-arbeidsplaats een belangrijke plaats in het onderwijs inneemt wordt de leerling reeds bij het begin van zijn opleiding met de arbeidsmarkt geconfronteerd. Dat heeft tot gevolg dat er zich reeds bij het begin van de studie aansluitingsproblemen kunnen voordoen tussen de vraag naar leerlingen door bedrijven en het aantal leerlingen dat wil instromen in het leerlingwezen. Met name als het gaat om een conjunctuurgevoelige bedrijfstak ontstaan er mogelijke problemen in de aansluiting. Als bedrijven vooral juist veel plaatsen openstellen voor leerlingen op het moment dat het goed gaat in het bedrijf, ontstaat het gevaar van pro-cyclisch beleid dat tot gevolg heeft dat er veel gediplomeerde vaklui beschikbaar komen op het moment dat het minder goed gaat. Het blijkt overigens dat de meeste technische opleidingen voor het leerlingwezen - waar het gevaar voor conjunctuurgevoeligheid het grootst is - een relatief stabiele instroom weten te bewerkstelligen.

In het ideale geval zou het vroegtijdige contact met de arbeidsmarkt aan het begin van de opleiding, tot een verbeterde aansluiting aan het einde van de opleiding moeten leiden. Uit de analyse blijkt echter doorgaans dat een dergelijke soepele aansluiting na afloop van de opleiding alleen wordt aangetroffen als het leerbedrijf zelf een concrete opleidingsbehoefte in de toekomst lijkt te hebben. Dit komt vooral tot uiting in het feit dat deze leerlingen vaak betere arbeidscontracten hebben 
gedurende hun opleiding en hun dienstverband veelal wordt voortgezet als de opleiding is voltooid. Omgekeerd blijken juist de leerlingen die een 'goedkope' aanstelling hebben, bijvoorbeeld een stageplaats, na afloop van de opleiding veelal niet terecht te kunnen bij hun huidige werkgever en juist zij veel moeite hebben om een geschikte plek op de arbeidsmarkt te vinden.

Vanuit twee gezichtspunten is het van belang dat ook het leerbedrijf een goede opleiding van de leerling als belangrijk ervaart doordat deze opleiding in de eigen behoefte aan vaklui moet voorzien. Ten eerste bevordert een dergelijk parallel belang dat leerlingen juist voor die vakgebieden worden opgeleid waarvoor een concrete toekomstige behoefte bestaat. Hierdoor loopt het onderwijs, zonder ingrijpen van buitenaf, reeds vooruit op de arbeidsmarktontwikkelingen. Daarnaast lijkt ook de kwaliteit van de opleiding het meest gebaat bij een duidelijk belang van de onderneming bij een goede opleiding. Indien het bedrijf vooral korte-termijnbaten heeft bij de arbeid van de leerling ontstaat er mogelijk een spanning tussen werken en leren die ten koste gaat van het scholingsproces. Voor situaties waarin het belang van de leerling en het bedrijf verder uiteenlopen lijken institutionele maatregelen, zoals bijvoorbeeld GOA's een belangrijke bijdrage te kunnen leveren.

Naast mogelijke problemen bij bepaalde richtingen in het leerlingwezen die voortkomen uit een spanning tussen werkbelang en leerbelang is het in het algemeen een zwakte van het leerlingwezen in vergelijking met het $\mathrm{MBO}$, dat de opleiding zich richt op een veel specifieker beroepsdomein. De gediplomeerde leerlingen zijn daardoor veel kwetsbaarder voor tegenvallende vraag in deze specifieke beroepen. Voor een verdere stimulering van het leerlingwezen is het derhalve van groot belang - voor zowel de beleidsinstanties als overheid en de landelijke organen, als voor de bedrijven - om inzicht te hebben in de verwachte marktontwikkelingen. Geconstateerd moet worden dat juist de sterk vakgerichte beroepen waar het leerlingwezen zich op richt qua vraagontwikkeling de komende vijf jaren naar verwachting achterblijven bij meer algemene beroepen waarin het MBO sterker is vertegenwoordigd. Stimulerende maatregelen ter bevordering van het leerlingwezen zullen dan ook rekening moeten houden met de arbeidsmarktontwikkelingen op de middellange termijn.

\section{Belangnijkste resultaten per landelijk orgaan}

\section{LOBAS (Landelijke Organisatie Beroepsopleidingen Agrarische Sectoren)}

Leerlingen die zijn aangesloten bij LOBAS zijn zowel in de landbouw en visserij als in de handel werkzaam. Ze zijn werkzaam als uitvoerend agranische personeel of als verkooppersoneel. De werkgelegenheid voor uitvoerend agranisch personeel zal de komende jaren naar verwachting afnemen. De werkgelegenheid voor verkooppersoneel zal daarentegen flink groeien. Leerlingen hebben vrijwel altijd betaald 
werk in het kader van het leerlingwezen. Minder dan de helft van de leerlingen heeft een vaste aanstelling. In de periode 1995-2000 zullen ongeveer 6.100 schoolverlaters van LOBAS op de arbeidsmarkt instromen. Hoewel deze arbeidsmarktinstroom lager is dan de arbeidsmarktinstroom in de periode 1990-1995 zal het aandeel van het leerlingwezen in de totale arbeidsmarktinstroom uit de richting MBO/LLW landbouw en natuurijke omgeving toenemen. Het totaal aantal baanopeningen voor schoolverlaters uit de richting MBO/LLW landbouw en natuurlijke omgeving is laag. Bovendien is ongeveer een kwart van deze baanopeningen vrijwel alleen voor MBO-schoolverlaters bestemd. Het arbeidsmarktperspectief voor het leerlingwezen in deze richting is sterk afhankelijk van de voorkeuren die werkgevers hebben voor (K)MBO'ers of mensen die een opleiding in het leerlingwezen hebben afgerond.

\section{SOBB (Stichting opleidingen Brood en Banket)}

De belangrijkste bedrijfssectoren voor SOBB zijn de handel en de voedings- en genotmiddelenindustrie. De werkgelegenheid voor bakkers en chocolademakers zal naar verwachting de komende vijf jaar gaan dalen. Vrijwel alle leerlingen van SOBB hebben betaald werk in het kader van het leerlingwezen. Het bruto uurloon van leerlingen is gemiddeld vrij hoog. De instroom in het leerlingwezen is niet zo conjunctuurgevoelig bij dit orgaan. Naar verwachting zullen de komende vijf jaar 2.800 gediplomeerden schoolverlaters van SOBB op de arbeidsmarkt instromen. Het leerlingwezen levert ongeveer tweederde van de totale arbeidsmarktinstroom uit de richting MBO/LLW consumptieve techniek. Niet alleen opleidingen van SOBB vallen hier overigens onder maar ook opleidingen van SVO. Het verwachte aantal baanopeningen voor schoolverlaters uit deze opleidingsrichting is gemiddeld. Een groot deel hiervan is voornamelijk voor mensen met een leerlingwezenopleiding bestemd. Daarom zijn de arbeidsmarktperspectieven voor mensen met een leerlingwezenopleiding in deze richting goed te noemen.

\section{SVO (Stichting voor de Vleessector)}

De werkgelegenheid van leerlingen van SVO is geconcentreerd in de handel. De leerlingen zijn werkzaam als voedings- en genotmiddelenbereiders en als verkooppersoneel. Terwijl de werkgelegenheid voor verkooppersoneel de komende jaren flink zal toenemen wordt voor de voedings- en genotmiddelenbereiders een afname van de werkgelegenheid verwacht. Leerlingen hebben bijna altijd betaald werk. In slechts een enkel geval heeft een leerling geen betaald werk maar een stageplaats. Verwacht wordt dat in de periode 1995-2000 ongeveer 2.800 leerlingen van SVO hun opleiding afronden en op de arbeidsmarkt instromen. Het leerlingwezen levert ongeveer tweederde van de totale arbeidsmarktinstroom uit de richting MBO/LLW consumptieve techniek. Niet alleen opleidingen van SVO vallen hier onder maar ook opleidingen van SOBB. Het verwachte aantal baanopeningen voor schoolverlaters uit deze opleidingsrichting is gemiddeld. Een groot deel hiervan is voornamelijk voor mensen met een leerlingwezenopleiding bestemd. Daarom zijn de arbeidsmarktper- 
spectieven voor mensen met een leerlingwezenopleiding in deze richting toch goed te noemen.

\section{VOC/BETEX (Onderwijscentrum voor Textiel en Confectie)}

VOC/Betex richt zich hoofdzakelijk op de textielindustrie die is ondergebracht in de categorie overige industrie, en in iets mindere mate ook op de handel. De meeste leerlingen zijn werkzaam als patroonmakers, naaiers en zeilmakers. De werkgelegenheid in deze beroepsklassen zal in de periode 1995-2000 naar verwachting dalen. De instroom in het leerlingwezen is bij dit orgaan vrij conjunctuurgevoelig. Naar verwachting zullen de komende vijf jaar ongeveer 800 gediplomeerden schoolverlaters van VOC/Betex op de arbeidsmarkt instromen. Het aandeel van het leerlingwezen in de totale arbeidsmarktinstroom uit de richting MBO/LLW textiel- en ledertechniek is vrij klein maar zal in de komende periode wel wat toenemen; van $15 \%$ naar $19 \%$. Het verwachte aantal baanopneningen voor schoolverlaters uit deze richting is gemiddeld. Een flink deel hiervan is voornamelijk voor (K)MBO-schoolverlaters bestemd. Toch zijn ook de arbeidsmarktperspectieven voor de leerlingwezenopleidingen in deze richting goed te noemen.

\section{VAS (Stichting Vakopleiding Schoen- en Lederwarenindustrie)}

Omdat dit orgaan slechts weinig leerlingen opleidt zijn er in RUBS te weinig waarnemingen beschikbaar voor dit orgaan om uitspraken te kunnen doen over de positie van mensen die een opleiding bij VAS volgen of hebben gevolgd. De conjunctuurgevoeligheid van de instroom in het leerlingwezen is gemiddeld. Er zullen de in de periode 1995-2000 ongeveer 100 gediplomeerden schoolverlaters van VAS de arbeidsmarkt betreden.

\section{SH\&M (Stichting Hout en Meubel)}

Leerlingen die zijn aangesloten bij SH\&M werken hoofdzakelijk in de overige industrie. Ze zijn werkzaam als timmerlieden en als stoffeerders en lederwarenmakers. In beide beroepsklassen zal de werkgelegenheid de komende jaren afnemen. De conjunctuurgevoeligheid van de instroom in het leerlingwezen is laag te noemen. De verwachte arbeidsmarktinstroom van gediplomeerden zal in de periode 19952000 ongeveer 3.500 bedragen. Het aandeel van het leerlingwezen in de totale arbeidsmarktinstroom uit de opleidingsrichting MBO/LLW bouwkunde zal de komende jaren dalen tot $57 \%$, in de afgelopen jaren was dit aandeel nog $63 \%$. Naast de opleidingen van SH\&M vallen overigens ook opleidingen van SVB en SVS onder deze opleidingsrichting. Het verwachte aantal baanopeningen voor schoolverlaters uit deze richting voor de komende jaren is gemiddeld. lets minder dan de helft van deze baanopeningen is voornamelijk voor (K)MBO'ers bestemd. Daarom zijn de arbeidsmarktperspectieven voor (K)MBO'ers in deze richting wat beter dan voor mensen met een leerlingwezenopleiding. Toch is ook het perspectief voor het leerlingwezen redelijk te noemen. 


\section{GOC (Grafisch Opleidingscentrum)}

De belangrijkste bedrijfssector voor het GOC is de overige industrie waaronder ook de grafische industrie valt. De meeste leerlingen van de GOC zijn werkzaam in de lagere grafische beroepen (produktiepersoneel grafische industrie). Leerlingen hebben vrijwel altijd betaald werk en de lonen van leerlingen liggen gemiddeld vrij hoog. De instroom van leerlingen bij dit orgaan is niet bijzonder conjunctuurgevoelig. Leerlingen van de GOC blijven na het voltooien van de opleiding relatief vaak bij hetzelfde bedrijf werken. Het percentage van de schoolverlaters met betaald werk is hoger dan gemiddeld. Bovendien is er voor de meeste schoolverlaters ook sprake van vast werk. Het werkloosheidspercentage is lager dan gemiddeld. Daar staat tegenover dat schoolverlaters uit de opleidingsrichting grafische techniek relatief weinig uitwijkmogelijkheden naar andere beroepen hebben. De komende jaren zullen ongeveer 7.400 schoolverlaters van het GOC de arbeidsmarkt betreden. De arbeidsmarktinstroom is daarmee wat lager dan in de afgelopen jaren. Bovendien zal het aandeel van het leerlingwezen in de arbeidsmarktinstroom uit de richting grafische techniek afnemen ten opzichte van het $\mathrm{K}(\mathrm{MBO})$. Het aantal baanopeningen voor schoolverlaters uit de richting grafische techniek is gemiddeld. Een groot deel, ongeveer $40 \%$, is echter alleen bestemd voor MBO-schoolverlaters. Dit betreft onder andere baanopeningen vanuit de middelbare technische ambachts- en industrieberoepen. Toch is ook het aantal baanopeningen vanuit beroepen die ook relevant zijn voor LLW-schoolverlaters uit deze richting, zoals de lagere grafische beroepen, voldoende groot. De arbeidsmarktperspectieven voor LLW-schooiverlaters uit de richting grafische techniek zijn daarom goed te noemen.

\section{VAPRO (Stichting Vakopleiding Procesindustrie)}

De belangrijkste bedrijfssector voor de VAPRO is de chemische industrie. Daarnaast zijn ook de overige industrie en de metaal en elektro-industrie van belang. Leerlingen zijn voornamelijk werkzaam in de beroepsklasse produktiepersoneel chemische industrie. De werkgelegenheid in deze beroepsklasse zal de komende jaren iets toenemen. De conjunctuurgevoeligheid van de instroom in het leerlingwezen is hoog. De verwachte arbeidsmarktinstroom van gediplomeerden voor de komende vijf jaar zal ongeveer 2.900 bedragen. Het leerlingwezen zal ongeveer de helft van de totale arbeidsmarkt instroom voor de richting MBO/LLW procestechniek leveren. De afgelopen vijf jaar bedroeg het aandeel van het leerlingwezen in deze richting nog $45 \%$. Het verwachte aantal baanopeningen voor de komende jaren is gemiddeld. Hoewel een aanzienlijk gedeelte van de baanopeningen voornamelijk voor (K)MBO schoolverlaters is bestemd is het arbeidsmarktperspectief van het leerlingwezen in deze richting toch goed. 


\section{SOM (Stichting Opleidingen Metaal)}

De SOM richt zich voornamelijk op de metaal- en elektro-industrie. Leerlingen van de SOM zijn werkzaam in de beroepsklasses lassers, constructeurs en edelsmeden, machinebank-, plaatwerkers en smeden en instrumentenmakers en onderhoudsmonteurs. De werkgelegenheid in deze beroepen zal naar verwachting de komende jaren afnemen. Slechts ongeveer de helft van de leerlingen heeft betaald werk. Veel leerlingen hebben alleen een stageplaats. Wel heeft meer dan de helft van de leerlingen met betaald tevens een vaste aanstelling. De conjunctuurgevoeligheid van de instroom van leerlingen is bij dit orgaan erg laag. Het percentage van de leerlingen dat na het voltooien van de opleiding bij het zelfde bedrijf werkzaam blijtt is lager dan gemiddeld. Met name leerlingen die geen betaald werk hadden tijdens de opleiding kunnen zelden bij hun leerbedrijf blijven. Leerlingen die betaald werk hadden tijdens de opleiding blijven wel redelijk vaak bij hun opleidingsbedrijf werkzaam. Het percentage van de gediplomeerden met betaald werk is bij dit orgaan lager dan gemiddeld. De werkloosheid is dan ook relatief hoog. Wel hebben schoolverlaters van de richting metaaltechniek relatief veel uitwijkmogelijkheden naar andere beroepen. De komende 5 jaar zullen ongeveer 13.100 schoolverlaters van de SOM op de arbeidsmarkt instromen, dat is iets minder dan de afgelopen vijf jaar. Het aandeel van het leerlingwezen in de totale arbeidsmarktinstroom in de richtingen MBO/LLW metaalkunde en werktuigbouwkunde zal licht afnemen ten opzichte van het (K)MBO. Het aandeel in de richting MBO/LLW fijnmechanische techniek zal gelijk blijven. Het aantal baanopeningen voor schoolverlaters uit de richting metaalkunde is gemiddeld. Een deel daarvan is echter voornamelijk voor MBO'ers bestemd. Voor leerlingwezen schoolverlaters uit de richting fijnmechanische techniek zijn de arbeidsmarktperspectieven goed. Voor LLW-schoolverlaters uit de richtingen metaalkunde en werktuigbouwkunde zijn de perspectieven sterk afhankelijk van de voorkeuren die werknemers hebben voor LLWers dan wel (K)MBO'ers.

\section{VEV (Vereniging Elektrotechnisch Vakonderwijs)}

De werkgelegenheid voor leerlingen die zijn aangesloten bij de VEV concentreert zich met name in de bouwnijverheid. Ook is een deel van de leerlingen werkzaam in de metaal- en elektro-industrie. De leerlingen worden voornamelijk opgeleid voor monteurs en controleurs elektrotechnische installaties. De werkgelegenheid in deze beroepen zal de komende jaren naar verwachting nauwelijks toenemen. Leerlingen hebben over het algemeen wat moeite om een leer-arbeidsplaats te vinden. Dat blijkt met name uit het feit dat veel leerlingen die recent met de opleiding zijn begonnen alleen het theoriegedeelte volgen. Wel liggen de lonen van leerlingen bij de VEV hoger dan gemiddeld. De conjunctuurgevoeligheid van de instroom in het leerlingwezen is laag. Het percentage van de leerlingen dat na het voltooien van de opleiding bij het leerbedrijf blijft werken is gemiddeld. Het percentage van de schoolverlaters met betaald werk is iets lager dan gemiddeld en de werkloosheid is 
dan ook vrij hoog. Daar staat tegenover dat de lonen van afgestudeerden gemiddeld hoog zijn. Bovendien zijn er ook veel uitwijkmogelijkheden naar andere beroepen voor LLW-schoolverlaters die een opleiding bij de VEV gevolgd hebben. Er zullen de komende vijf jaar ongeveer 12.000 schoolverlaters van de VEV op de arbeidsmarkt instromen. Het aandeel van het leerlingwezen in de totale arbeidsmarktinstroom van de opleidingsrichting MBO/LLW elektrotechniek zal de komende vijf jaar licht toenemen ten opzichte van de afgelopen vijf jaar. Het verwachte aantal baanopeningen voor schoolverlaters in deze richting is gemiddeld. Ongeveer de helft van de baanopeningen zal echter naar verwachting alleen voor MBO'ers en KMBO'ers bestemd zijn. De arbeidsmarktperspectieven voor LLW-schoolverlaters uit de richting MBO/LLW elektrotechniek zijn daarom erg onzeker en strek afhankelijk van de voorkeuren van werknemers.

\section{VOC-car (Stichting Vakopleiding Carrosseriebedrijf)}

De meeste leerlingen van VOC-car werken in de overige commerciële dienstverlening. Ook werkt een aantal leerlingen in de metaal- en elektrotechniek. Ze zijn werkzaam in de beroepsklassen machinebank-, plaatwerkers en smeden, automonteurs en herstellers en produktiepersoneel aardewerk- en glasindustrie. Voor al deze beroepsklassen wordt een werkgelegenheidsdaling verwacht. De instroom in het leerlingwezen is bij dit orgaan nogal conjunctuurgevoelig. Naar verwachting zullen in de periode 1995-2000 ongeveer 1.900 gediplomeerden op de arbeidsmarkt instromen. Het aandeel van het leerlingwezen in de totale arbeidsmarktinstroom uit de richting MBO/LLW motorvoertuigentechniek zal dalen van $54 \%$ in de periode 1990-1995 naar 49\% in de periode 1995-2000. Niet alleen opleidingen van VOC-car vallen overigens onder de richting MBO/LLW motorvoertuigentechniek maar ook opleidingen van INNOVAM. Het verwachte aantal baanopeningen voor schoolverlaters uit deze richting is laag. Bovendien is een aanzienlijk gedeelte hiervan voornamelijk voor (K)MBO-schoolverlaters bestemd. Daarom zijn de arbeidsmarktperspectieven voor het leerlingwezen in deze richting matig tot slecht.

\section{SVB (Stichting Vakopleiding Bouwbedrijf)}

De belangrijkste bedrijfssector is de bouwnijverheid. Leerlingen van de SVB zijn werkzaam als timmerlieden en als metselaars en stukadoors. Dat zijn beroepen waarvoor een afnemende werkgelegenheid wordt verwacht. De meeste leerlingen hebben een betaalde leer-arbeidsplaats. Het percentage van de leerlingen dat tevens een vaste aanstelling heeft is lager dan gemiddeld. De instroom in het leerlingwezen is nauwelijks conjunctuurgevoelig. Verwacht wordt dat rond de 9.800 gediplomeerden van SVB in de periode 1995-2000 op de arbeidsmarkt zullen instromen. Het aandeel van het leerlingwezen in de totale arbeidsmarktinstroom uit de opleidingsrichting MBO/LLW bouwkunde zal de komende jaren dalen tot $57 \%$, in de afgelopen jaren was dit aandeel nog $63 \%$. Naast de opleidingen van SVB vallen overigens ook opleidingen van SH\&M en SVS onder de opleidingsrichting 
MBO/LLW bouwkunde. Het verwachte aantal baanopeningen voor schoolverlaters voor de komende jaren is gemiddeld. lets minder dan de helft van deze baanopeningen is voornamelijk voor (K)MBO'ers bestemd. Daarom zijn de arbeidsmarktperspectieven voor (K)MBO'ers in deze richting wat beter dan voor mensen met een leerlingwezenopleiding. Toch is ook het perspectief voor het leerlingwezen redelijk te noemen.

\section{SBW (Stichting Beroepsopleidingen Weg- en Waterbouw)}

De werkgelegenheid van leerlingen die aangesloten zijn bij de SBW concentreert zich in de bouwnijverheid. Ze zijn werkzaam als machinisten bouw en industrie, metselaars en stukadoors en wegenbouwkrachten en buizenleggers. Alleen voor de machinisten bouw en industrie wordt een toename van de werkgelegenheid verwacht. De werkgelegenheid voor metselaars en stukadoors en wegenbouwkrachten en buizenleggers zal gaan dalen. De conjunctuurgevoeligheid van de instroom in het leerlingwezen is bij dit orgaan gemiddeld. Naar verwachting zullen de komende vijf jaar rond de 1.800 schoolverlaters van SBW de arbeidsmarkt betreden. Het leerlingwezen zal ongeveer $34 \%$ van de totale arbeidsmarktinstroom in de richting MBO/LLW weg- en waterbouwkunde leveren. In de afgelopen vijf jaar was dat nog $40 \%$. Het verwachte aantal baanopeningen voor schoolverlaters uit deze richting is gemiddeld. Het merendeel van deze baanopeningen is echter voor (K)MBO'ers bestemd. De arbeidsmarktperspectieven voor het leerlingwezen in deze richting zijn daarom matig tot slecht.

\section{Intechnium}

De belangrijkste bedrijfssector voor Intechnium is de bouwnijverheid. Meer dan $93 \%$ van de werkgelegenheid van leerlingen van Intechnium is geconcentreerd in deze sector. Intechnium leidt met name loodgieters en installateurs op. De werkgelegenheid voor loodgieters en installateurs zal naar verwachting de komende jaren sterk dalen. Toch hebben leerlingen van Intechnium vrij vaak een betaalde leerarbeidsplaats. Het percentage van de leerlingen die na het voltooien van de opleiding bij het leerbedrijf blijft werken is hoog. Om die reden is ook het percentage van de schoolverlaters met betaald werk erg hoog. Bovendien heeft vrijwel iedereen ook een vaste aanstelling. Het bruto uurloon van schoolverlaters ligt hoger dan gemiddeld. Wel geldt dat de schoolverlaters relatief weinig uitwijkmogelijkheden hebben naar andere beroepen. De komende vijf jaar zullen ongeveer 7.000 gediplomeerde schoolverlaters van Intechnium op de arbeidsmarkt instromen.

\section{SVS (Stichting Vakopleiding Schilders en stukadoorsbedrijf)}

Leerlingen van SVS werken hoofdzakelijk in de bouwnijverheid. De meesten zijn werkzaam als schilder. De komende jaren zal de werkgelegenheid voor schilders afnemen. De instroom in het leerlingwezen is bij dit orgaan niet zo conjunctuurgevoelig. Verwacht wordt dat de arbeidsmarktinstroom van gediplomeerden van de 
SVS de komende vijf jaar ongeveer 4.100 zal bedragen. Het aandeel van het leerlingwezen in de totale arbeidsmarktinstroom uit de opleidingsrichting MBO/LLW bouwkunde zal de komende jaren dalen naar $57 \%$, in de afgelopen jaren was dit aandeel nog $63 \%$. Naast de opleidingen van SVS vallen overigens ook opleidingen van SH\&M en SVB onder de opleidingsrichting MBO/LLW bouwkunde. Voor de komende jaren is het verwachte aantal baanopeningen voor schoolverlaters gemiddeld. lets minder dan de helft van deze baanopeningen is voornamelijk voor (K)MBO'ers bestemd. Daarom zijn de arbeidsmarktperspectieven voor (K)MBO'ers in deze richting wat beter dan voor mensen met een leerlingwezenopleiding. Toch is ook het perspectief voor het leerlingwezen redelijk te noemen.

INNOVAM (Innovatie- en Onderwijscentrum Motorvoertuigen en Tweewielersbranche)

De belangrijkste bedrijfssector voor INNOVAM is de overige commerciële dienstverlening. Leerlingen zijn voomamelijk werkzaam als automonteurs en herstellers. De werkgelegenheid in deze beroepsklasse zal in de periode 1995-2000 afnemen. Leerlingen hebben meestal een betaalde leer-arbeidsplaats. Toch komt het ook voor dat leerlingen in plaats van een betaalde arbeidsplaats een stageplaats hebben. Leerlingen die een betaalde arbeidsplaats hebben, hebben meestal ook een vaste aanstelling. De instroom in het leerlingwezen is erg conjunctuurgevoelig. De komende vijf jaar zullen ongeveer 9.000 gediplomeerden van INNOVAM op de arbeidsmarkt instromen. Het aandeel van het leerlingwezen in de totale arbeidsmarktinstroom uit de richting MBO/LLW motorvoertuigentechniek zal dalen van $54 \%$ in de periode $1990-1995$ naar $49 \%$ in de periode $1995-2000$. Niet alleen opleidingen van INNOVAM vallen overigens onder de richting MBO/LLW motorvoertuigentechniek maar ook opleidingen van VOC-car. Het verwachte aantal baanopeningen voor schoolverlaters uit deze richting is laag. Bovendien is een aanzienlijk gedeelte hiervan voornamelijk voor (K)MBO-schoolverlaters bestemd. Daarom zijn de arbeidsmarktperspectieven voor het leerlingwezen in deze richting matig tot slecht.

\section{SWWISLW (Vakopleiding Wegvervoer)}

De werkgelegenheid van leerlingen van SWWISLW is verdeeld over meerdere sectoren. De belangrijkste sectoren zijn transport, opslag en communicatie, de handel en de overige commerciële dienstverlening. Leerlingen zijn werkzaam in de beroepsklassen chauffeurs en spoorwegpersoneel, expeditiemedewerkers en automonteurs en herstellers. De werkgelegenheid voor chauffeurs en spoorwegpersoneel en expeditiemedewerkers zal naar verwachting toenemen terwijl de werkgelegenheid voor automonteurs en herstellers zal gaan dalen. Leerlingen hebben bijna altijd een betaalde leer-arbeidsplaats maar zelden een vaste aanstelling. Het bruto uurloon van leerlingen is gemiddeld genomen vrij laag. De conjunctuurgevoeligheid van de instroom is gemiddeld. De verwachte arbeidsmarktinstroom van gediplomeerden over de periode 1995-2000 bedraagt ongeveer 2.400 . Het leerlingwezen 
levert ongeveer èenderde van de totale arbeidmarktinstroom van schoolverlaters uit de richting MBO/LLW haven en vervoer. Naast de opleidingen van SWW/SLW vallen ook opleidingen van KOFS en SLHV onder deze richting. Het verwacht aantal baanopeningen voor schoolverlaters uit deze richting is gemiddeld. Meer dan èenderde hiervan is vooral bestemd voor mensen met een leerlingwezenopleiding. De perspectieven voor het leerlingwezen zijn in deze richting daarom goed te noemen.

\section{KOFS (Stichting Koninklijk Onderwijsfonds voor de Scheepvaart}

De werkgelegenheid van leerlingen aangeloten bij de KOFS is geconcentreerd in de sector transport, opslag en communicatie. Leerlingen werken voornamelijk als scheepsdek- en machinekamerpersoneel. De werkgelegenheid in deze beroepsklassen zal in de toekomst gaan dalen. Rond de 200 gediplomeerden van KOFS zullen de komende vijf jaar op de arbeidsmarkt instromen. Het leerlingwezen levert ongeveer eeenderde van de totale arbeidmarktinstroom van schoolverlaters uit de richting MBO/LLW haven en vervoer. Naast de opleidingen van KOFS vallen ook opleidingen van SWWISLW en SLHV onder deze richting. Het verwacht aantal baanopeningen voor schoolverlaters uit deze richting is gemiddeld. Meer dan èenderde hiervan is vooral bestemd voor mensen met een leerlingwezenopleiding. De perspectieven voor het leerlingwezen zijn in de richting MBO/LLW haven en vervoer daarom goed te noemen.

\section{SLHV (Stichting Leerlingwezen Haven- en Vervoersbedrijf)}

De belangrijkste bedrijfssector voor SLHV is de sector transport, opslag en communicatie. Ook werk een deel van de leerlingen in de handel. Leerlingen zijn werkzaam in de beroepsklassen commercieel administratieve medewerkers, expeditiemedewerkers en secretaressen en typisten. De werkgelegenheid voor expeditiemedewerkers zal toenemen terwijl de werkgelegenheid in de twee overige beroepsklassen zal gaan dalen. De conjunctuurgevoeligheid van de instroom is gemiddeld. Naar verwachting zullen de komende vijf jaar ongeveer 400 gediplomeerden schoolverlaters van SLHV de arbeidsmarkt betreden. Het leerlingwezen levert ongeveer èenderde van de totale arbeidmarktinstroom van schoolverlaters uit de richting MBO/LLW haven en vervoer. Naast de opleidingen van SLHV vallen ook opleidingen van SWW/SLW en KOFS onder deze richting. Het verwacht aantal baanopeningen voor schoolverlaters uit deze richting is gemiddeld. Meer dan èenderde hiervan is vooral bestemd voor mensen met een leerlingwezenopleiding. De perspectieven voor het leerlingwezen zijn in deze richting daarom goed te noemen.

\section{SVGB (Stichting Vakopleiding Gezondheidstechnische Beroepen)}

Leerlingen van de SVGB zijn voornamelijk in de handel werkzaam. Verder werkt ook een aantal leerlingen in de metaal- en elektrotechniek en in de kwartaire 
dienstverlening. Men is werkzaam in de beroepsklassen opticiens en apothekersassistenten en instrumentenmakers en onderhoudsmonteurs. Verwacht wordt dat de werkgelegenheid voor opticiens en apothekersassistenten zal toenemen terwijl de werkgelegenheid voor instrumentenmakers en onderhoudsmonteurs zal gaan dalen. De conjunctuurgevoeligheid van de instroom is gemiddeld te noemen. Rond de 1.600 gediplomeerde schoolverlaters van de SVGB zullen in de periode 1995-2000 op de arbeidsmarkt instromen. Ongeveer $35 \%$ van de totale arbeidsmarktinstroom vanuit de richting MBO/LLW medisch laboratorium komt uit het leerlingwezen. Het verwachte aantal baanopeningen voor schoolverlaters is gemiddeld. Het grootste gedeelte hiervan zal voornamelijk voor mensen met een leerlingwezenopleiding bestemd zijn. De arbeidsmarktperspectieven voor het leerlingwezen in deze richting zijn dan ook goed.

\section{SVK (Stichting Vakopleiding Kappersbedrijf)}

Zoals verwacht zijn leerlingen die zijn aangesloten bij SVK werkzaam in de overige commerciële dienstverlening. Hoewel de werkgelegenheid in deze sector de komende jaren flink zal groeien zal de werkgelegenheid voor kappers en schoonheidsspecialisten naar verwachting afnemen. Ook de vervangingsvraag vanuit deze beroepen is vrij laag. Leerlingen bij de SVK hebben altijd betaald werk, dit is echter een voorwaarde om de opleiding te kunnen volgen. Een verminderde vraag naar leerlingen wordt bij dit orgaan dus niet opgevangen door extra (onbetaalde) stageplaatsen in plaats van betaalde leerplaatsen en leidt daarom direct tot een daling van het aantal leerlingen. De conjunctuurgevoeligheid van de instroom is gemiddeld. Leerlingen van SVK hebben vaker dan gemiddeld een vaste aanstelling. Het gemiddeld bruto uurloon van de leerlingen is echter lager dan gemiddeld. $\mathrm{Na}$ het voltooien van de opleiding kunnen de leerlingen redelijk vaak bij hun leerbedrijf blijven werken. Vrijwel alle schoolverlaters van SVK hebben een krap jaar na het voltooien van de opleiding een betaalde baan. Wel is het percentage dat een vaste aanstelling heeft wat lager dan gemiddeld. Ook na het afstuderen blijt het loon van de kappers wat achter bij dat van schoolverlaters uit andere richtingen. De uitwijkmogelijkheden naar andere beroepen zijn voor schoolverlaters van SVK beperkt. De komende vijf jaar zullen iets meer 7.000 schoolverlaters van SVK op de arbeidsmarkt instromen.

\section{$\mathrm{OCH}$ (Onderwijscentrum Horeca)}

Leerlingen die zijn aangesloten bij $\mathrm{OCH}$ werken hoofdzakelijk in de overige commerciële dienstverlening in de beroepsklasse keuken- en serveerpersoneel. De werkgelegenheid voor keuken- en serveerpersoneel zal in de periode 1995-2000 toenemen. Vrijwel alle leerlingen hebben betaald werk in het kader van het leerlingwezen, maar men heeft vrijwel nooit een vaste aanstelling. De conjunctuurgevoeligheid van de instroom in het leerlingwezen is gemiddeld. Verwacht wordt dat 
ongeveer 7.400 gediplomeerden schoolverlaters van $\mathrm{OCH}$ de komende vijf jaar op de arbeidsmarkt zullen instromen.

OVD (Opleidingsinstituut voor de distributie)

De werkgelegenheid voor leerlingen van OVD is geconcentreerd in de handel. De OVD leidt voornamelijk verkooppersoneel op. De werkgelegenheid voor verkooppersoneel zal de komende jaren naar verwachting flink toenemen. De meeste leerlingen die een opleiding volgen bij OVD hebben betaald werk. Bovendien heeft men vrij vaak ook een vaste aanstelling. Daar staat tegenover dat het gemiddeld bruto uurloon van leerlingen bij de OVD wat lager ligt dan bij andere organen. De conjunctuurgevoeligheid van de instroom is gemiddeld. Na het behalen van het leerlingwezendiploma blijft men vrij vaak bij het leerbedrijf in dienst. Het percentage van de schoolverlaters dat betaald werk heeft is dan ook redelijk hoog. Het bruto uurloon van schoolverlaters is gemiddeld genomen echter wat aan de lage kant. Naar verwachting zullen de komende vijf jaar ongeveer 5.500 mensen die een opleiding bij OVD hebben voltooid op de arbeidsmarkt instromen. Het aandeel van leerlingwezenschoolverlaters op het totaal aantal schoolverlaters in de richting $\mathrm{MBO} / \mathrm{LLW}$ handel is overigens erg klein, namelijk nog geen $10 \%$. Het aantal baanopeningen voor schoolverlaters uit de richting MBO/LLW handel zal de komende periode naar verwachting gemiddeld zijn. Meer dan de helft van deze baanopeningen zal echter voornamelijk voor mensen met een opleiding op MBOniveau bestemd zijn. Het arbeidsmarktperspectief voor mensen die een leerlingwezenopleiding in de richting handel hebben gevolgd zal daarom sterk afhankelijk zijn van de voorkeuren van werknemers. Als werkgevers een voorkeur hebben voor leerlingwezenschoolverlaters boven MBO'ers of geen duidelijke voorkeuren hebben dan zijn de perspectieven redelijk tot goed.

ECABO (Stichting Landelijk Orgaan te bevordering van Opleidingen voor de Economische en Administratieve beroepen)

De werkgelegenheid van leerlingen die een opleiding bij ECABO volgen is verspreid over meerdere bedrijfssectoren. De belangrijkste sectoren zijn het bank- en verzekeringswezen, de overheid, de overige commerciële dienstverlening en de handel. ECABO leidt onder meer op voor secretaressen en typisten, administrateurs en bankpersoneel en programmeurs en systeemanalisten. Opvallend is dat leerlingen die aangesloten zijn bij ECABO meestal geen betaald werk hebben in het kader van het leerlingwezen maar een stageplaats zowel met als zonder onkostenvergoeding. Ook is de instroom in het leerlingwezen bij dit orgaan erg conjunctuurgevoelig. $\mathrm{Na}$ het voltooien van de opleiding blijft men in de meest gevallen ook niet bij het leerbedrijf werkzaam. Toch is het percentage van de schoolverlaters dat betaald werk heeft slechts iets lager dan gemiddeld. Het percentage dat ook vast werk heeft is wel veel lager dan gemiddeld. Bovendien is ook het bruto uurloon van schoolverlaters over het algemeen vrij laag. Verder valt op dat schoolverlaters van ECABO 
minder tevreden zijn over de aansluiting tussen de gevolgde opleiding en het huidige beroep dat schoolverlaters van andere organen. Schoolverlaters van ECABO hebben redelijk veel uitwijkmogelijkheden naar andere beroepen. In de periode 1995-2000 zullen ongeveer 5.500 gediplomeerden schoolverlaters van ECABO op de arbeidsmarkt instromen. Het aandeel van het leerlingwezen in de totale instroom MBO/LLW in de richting MBO/LLW administratief is slechts $3 \%$ en in de richting MBO/LLW secretarieel slechts $8 \%$. Het verwachte aantal baanopeningen voor schoolverlaters over de periode $1995-2000$ is gemiddeld voor de richting MBO/LLW administratief maar laag voor de richting MBO/LLW secretarieel. Het leerlingwezen heeft met name in de richting MBO/LLW secretarieel echter vrij veel concurrentie van het (K)MBO. De perspectieven voor het leerlingwezen in deze richting zijn daarom sterk afhankelijk van de voorkeuren van werknemers voor mensen met een leerlingwezenopleiding of een (K)MBO-opleiding. In de richting MBO/LLW administratief is het perspectief voor het leerlingwezen goed.

\section{OVDB (Landelijke Stichting Opleiding Verzorgende en Dienstverlenende Beroepen)}

De OVDB richt zich op de kwartaire dienstverlening. Het orgaan verzorgt opleidingen voor onder andere kinder-, gezins- en bejaardenverzorgdenden. Leerlingen die zijn aangesloten bij OVDB hebben vaak geen betaalde arbeidsplaats maar een stageplaats. Degenen met een stageplaats ontvangen bovendien meestal geen onkostenvergoeding. Waarschijnlijk is daardoor de conjunctuurgevoeligheid van de instroom bij dit orgaan laag. Degenen die tijdens de opleiding wel een betaalde plaats hadden blijven meestal in dienst van het leerbedrijf na het voltooien van de opleiding. Opvallend is dat vrijwel alle schoolverlaters van OVDB die werk hebben gevonden ook een vaste baan hebben. De lonen van schoolverlaters van OVDB liggen iets hoger dan gemiddeld. Wel geldt dat de uitwijkmogelijkheden naar andere beroepen beperkt zijn. Naar verwachting zullen de komende vijf jaar ongeveer 8.000 schoolverlaters die een leerlingwezenopleiding bij OVDB hebben voltooid de arbeidsmarkt betreden. Het aandeel van het leerlingwezen in de richting MBO/LLW verzorging zal overigens flink dalen. Het aantal baanopeningen voor schoolverlaters in deze richting is gemiddeld. Een klein deel van de baanopeningen zal vrijwel alleen voor mensen met een leerlingwezenopleiding bestemd zijn, bijna de helft van de baanopeningen is alleen voor (K)MBO-schoolverlaters bestemd en de rest voor zowel LLW-schoolverlaters als (K)MBO-schoolverlaters. Het arbeidsmarktperpectief is daarom onzeker en zal afhangen van de voorkeuren die werknemers hebben voor (K)MBO- of leerlingwezenschoolverlaters. 



\section{Literatuur}

Bjorn, Niels Hennning (1995), The Market for new apprentices, Causes and consequences of persistent unemployment,chapter 2, Working Paper 95-05, Centre for Labour market and Social research, University of Aarhus and Aarhus School of business.

Borghans, L., A. de Grip, R. Dekker, A. Matheeuwsen, W. Smits, E. Willems, (1995), Methodiek van het informatiesysteem Onderwijs-Arbeidsmarkt 1995, ROA-W-1995/3, Maastricht

Commissie Dualisering (1993), Beroepsvorming langs vele wegen, Ministerie van Onderwijs Onderwijs en Wetenschappen, Den Haag.

Commissie Peil (1994), Leerlingwezen in meervoud; verkenning van mogelijkheden en grenzen van groei.

Grip, A. de, H. Berendsen, L. Borghans, R.J.P. Dekker (1993), Toekomstverkenning leerling wezen, ROA-R-1993/4, Maastricht.

Killingsworth, M. R. (1982), "Learning by Doing" and "Investment in Training": A Synthesis of two "Rival" Models of the Life Cycle, Review of Economic Studies, XLIX, pp 263-271.

LDC, vereninging BVE, COLO, AOC-Raad (1994), Studiegids MBO en leerlingwezen 1995, alle opleidingen in het $M B O$ en leerlingwezen, Meppel.

Ministerie van Sociale Zaken en Werkgelegenheid (1993), Meer werk, meer werk, Den Haag.

ROA (1995a), De arbeidsmarkt naar opleiding en beroep tot 2000, ROA-R-1995/3, Maastricht.

ROA (1995b), De arbeidsmarkt naar opleiding en beroep tot 2000, Statistische bijlage, ROAR-1995/3B, Maastricht.

Smoorenburg, M.S.M., R.K.W van der Velden (1995a), Werken en leren in het leerlingwezen, de positie van het BBO: schooljaar 1992-1993, Stichting Landelijk Dienstverlenend Centrum voor Studie- en Beroepskeuzevoorlichting, Leeuwarden.

Smoorenburg, M.S.M., R.K.W van der Velden (1995b), Schoolverlaters op de arbeidsmarkt; de uitstroom en bestemming van het schooljaar 1992-1993, Stichting Landelijk Dienstverlenend Centrum voor Studie- en Beroepskeuzevoorlichting, Leeuwarden.

Smoorenburg, M.S.M., R.K.W van der Velden (1995c), Training en beloning van schoolverlaters, paper gepresenteerd op de Onderwijs Research Dagen, Groningen:19-21 juni 1995 Maastricht.

Velden, R. van der, B.Lodder (1995), Alternative Routes from Vocational Education to the Labour Market, Educational Research and Evaluation, Vol. 1, No. 2, pp. 109-128.

Vries, I. de, F. Heere (1993), Kosten en baten van het leerlingwezen bij bedrijen, Organisatie voor Strategisch Arbeidsmarktonderzoek, Den Haag. 


\section{Appendix A Lijst met afkortingen landelijke organen voor het leerlingwezen}

$\begin{array}{ll}\text { ECABO } & \text { Stichting Landelijk Orgaan ter Bevordering van Opleidingen voor } \\ & \text { de Economische en Administratieve Beroepen } \\ \text { GOC } & \text { Grafisch Opleidingscentrum } \\ \text { INNOVAM } & \text { Innovatie- en Onderwijscentrum Motorvoertuigen- en Tweewie- } \\ & \text { lersbranche } \\ \text { Intechnium } & \text { Voorheen: Stichting Opleidingen Installatietechniek (SOI) } \\ \text { KOFS } & \text { Stichting Koninklijk Onderwijsfonds voor de Scheepvaart } \\ \text { LOBAS } & \text { Landelijke Organisatie Beroepsopleidingen Agrarische Sectoren } \\ \text { OCH } & \text { Onderwijscentrum Horeca } \\ \text { OVD } & \text { Opleidingsinstituut voor de Distributie } \\ \text { OVDB } & \text { Landelijke Stichting Opleiding Verzorgende en Dienstverlenende } \\ & \text { Beroepen } \\ \text { SBW } & \text { Stichting Beroepsopleidingen Weg- en Waterbouw } \\ \text { SH\&M } & \text { Stichting Hout- \& Meubel } \\ \text { SLHV } & \text { Stichting Leerlingwezen Haven- en Vervoerbedrijf } \\ \text { SWWISLW } & \text { Vakopleiding wegvervoer } \\ \text { SOBB } & \text { Stichting Opleidingen Brood en Banket } \\ \text { SOM } & \text { Stichting Opleidingen Metaal } \\ \text { SVB } & \text { Stichting Vakopleiding Bouwbedrijf } \\ \text { SVGB } & \text { Stichting Vakopleiding Gezondheidstechnische Beroepen } \\ \text { SVK } & \text { Stichting Vakopleiding Kappersbedrijf } \\ \text { SVO } & \text { Stichting voor de vleessector } \\ \text { SVS } & \text { Stichting Vakopleiding Schilders- en Stukadoorsbedrijf } \\ \text { VAPRO } & \text { Stichting Vakopleiding Procesindustrie } \\ \text { VAS } & \text { Stichting Vakopleiding Schoen- en Lederwarenindustrie } \\ \text { VEV } & \text { Vereniging Elektrotechnisch Vakonderwijs } \\ \text { VOC (car) } & \text { Stichting Vakopleiding Carrosseriebedrijf } \\ \text { VOC/BETEX } & \text { Onderwijscentrum voor Textiel en Confectie (fusie van Stichting } \\ & \text { vakopleiding Confectie Industrie en Stichting Beroepsopleidingen } \\ & \text { Textielindustrie. } \\ & \end{array}$





\title{
Appendix B Opleidingsrichtingen uit hoofdstuk 4
}

\author{
Technisch: Metaaltechniek \\ Leerlingwezen \\ BBO Metaaltechniek | - combinatiedraaier \\ BBO Metaaltechniek I - instrumentdraaier/-frezer \\ BBO Metaaltechniek I - kotteraar \\ BBO Metaaltechniek I - profielslijper \\ BBO Metaaltechniek I - universeel slijper \\ BBO Metaaltechniek I - schaver \\ BBO Metaaltechniek I - machinewerker (verspan.bew) \\ BBO Metaaltechniek I - handvormer \\ BBO Metaaltechniek I - modelmaker (hout) \\ BBO Metaaltechniek I - modelmaker (metaal) \\ BBO Metaaltechniek I - fijnbankwerker \\ BBO Metaaltechniek I - instrumentmaker \\ BBO Metaaltechniek I - stempelbankwerker \\ BBO Metaaltechniek I - praktijkopleider \\ BBO Metaaltechniek I - draaier \\ BBO Metaaltechniek I - frezer \\ BBO Metaaltechniek I - machinaal verspaner \\ BBO Metaaltechniek I - machinebankwerker fijnmet. \\ BBO Metaaltechniek I - machinebankwerker werktuigb \\ BBO Metaaltechniek I - aspirant gieterijtechnicus \\ BBO Metaaltechniek I - bankwerker montage/onderh. \\ BBO Metaaltechniek I - machinewerker \\ BBO Metaaltechniek I - kotteraar \\ BBO Metaaltechniek I - machinewerker \\ BBO Metaaltechniek II - autogeenlasser \\ BBO Metaaltechniek II - lasser \\ BBO Metaaltechniek II - bankw. stalen ramen/deuren \\ BBO Metaaltechniek II - non-ferro ramen/deuren \\ BBO Metaaltechniek II - kunststofbewerk. app.bouw \\ BBO Metaaltechniek II - isoleerder/plaatwerker \\ BBO Metaaltechniek II- plaatwerker roestvrij staal \\ BBO Metaaltechniek II - fijnplaatwerker hand/mach. \\ BBO Metaaltechniek II - constructiewerker \\ BBO Metaaltechniek II - forceur \\ BBO Metaaltechniek II - booglasser \\ BBO Metaaltechniek II - constructiewerker - lasser
}


BBO Metaaltechniek II - plaat- en constructiewerk.

BBO Metaaltechniek II - plaatwerker

BBO Metaaltechniek II - booglassen

BBO Metaaltechniek II - constructiewerker

BBO Metaaltechniek II - fijnplaatwerker

KMBO

KMBO metaalbewerking

MBO

MTS fijnmechanische techniek

MTS fijnmechanische techniek + metaal-A

MTS fijnmechanische techniek + metaal-B

MTS metaal-A

MTS metaal-B

MTS metaalkunde

Technisch: Elektrotechniek

Leerlingwezen

BBO Elektrotechniek - mont. elektr. vliegtuiginst.

BBO Elektrotechniek- monteur telecommunicatie-inst

BBO Elektrotechniek - monteur elektrisch railvoert

BBO Elektrotechniek - ass. mont. elektr. montage

BBO Elektrotechniek-install. mont. meet/regeltech.

BBO Elektrotechniek-onderhoudsmont. meet/regeltech

BBO Elektrotechniek-monteur sterkstroominstallatie

BBO Elektrotechniek - mont. elektr. bedrijfsinstal

BBO Elektrotechn.-mont. elektr.\& elektron.bedr.app

BBO Elektrotechniek - monteur laagspanningsnetten

BBO Elektrotechniek - mont. elektrotechn. wikkelen

BBO Elektrotechniek - mont. elektrotechn. panelen

BBO Elektrotechniek - monteur TV- en radio-app.

BBO Elektrotechniek - mont. indust. electronica

BBO Elektrotechniek-ass. techn. sterkstroominstal.

BBO Elektrotechn.- ass. techn. elektr. bedr.instal

BBO Elektrotechn.- ass. techn. indust. electronica

BBO Elektrotechn.- ass.techn. TV- en radio-appar.

BBO Elektrotechniek - ass.techn.communicatiesyst.

BBO Elektrotechniek - ass.mont. sterkstroominstall

BBO Elektrotechniek - ass.mont. laagspanningsnet.

BBO Elektrotechn.- ass.mont. telecommunicatie ins

BBO Elektrotechniek - ass.techn. vliegtuiginstall. 
BBO Elektrotechn.- ass.techn.middenspanningsinstal

BBO Elektrotechniek - ass. indust. automatisering

BBO Elektrotechniek - ass. indust. automatisering

BBO Elektrotechniek - monteur sterkstroominst. MSI

BBO Elektrotechn.- monteur elektr. bedr.instal MBI

BBO Elektrotechn.- monteur communicatie-inst. $\mathrm{MCl}$

BBO Elektrotechn.- monteur communicatienetten $\mathrm{MCN}$

BBO Elektrotechn.- ass.mont.sterkstroominst. AMSI

BBO Elektrotechn.-ass.mont.electr.bedr.inst. AMBI

BBO Elektrotechniek - ass.mont. comm.-inst. AMCl

BBO Elektrotechn.-ass.mont.communicatienetten AMCN

KMBO

KMBO elektrotechniek

MBO

MTS elektrotechniek

MTS elektrotechniek commerciOle techniek

MTS elektrotechniek elektronica

MTS elektrotechniek energietechniek

MTS elektrotechniek technische computerkunde

MTS elektrotechniek besturingstechniek

MTS electrotechniek meet- en regeltechniek

MTS Elektrotechniek electr. installatietechniek

Technisch: Installatietechniek

Leerlingwezen

BBO Installatietechniek - installatietekenaar W

BBO Installatietechn. - montage ass.instal.techn.

BBO Installatietechniek - ass.installatietechnicus

BBO Installatietechn.- 2e mont. distr.techn. -gas

BBO Installatietechn.- 2e mont.distr.techn.-water

BBO Installatietechniek - installatiemonteur

BBO Installatietechniek - verwarmingsmonteur

BBO Installatietechniek - installatiemonteur

BBO Installatietechn.- ass.mont.distr.techn. water

BBO Installatietechn.- ass.mont. distr.techn. gas

BBO Installatietechn.- ass. installatiemonteur

BBO Installatietechniek - ass. verwarmingsmonteur

BBO Installatietechniek - onderhoudsmonteur

BBO Installatietechniek - ass. dakbedekkingsmont. 
BBO Installatietechniek - ass.distr.monteur gas

BBO Installatietechniek - ass.distr.monteur water

$K M B O$

KMBO installatietechniek

MBO

MTS werktuigbouwkunde installatietechniek

Technisch: Consumptieve techniek

Leerlingwezen

BBO Consumptieve techniek - brood/banketbakker

BBO Consumptieve techn.- 2e banketsbakkersbediende

BBO Consumptieve techn.- chocoladebereider/verwerk

BBO Consumptieve techniek - suikerwerkbereider

BBO Consumptieve techniek - restaurantkok

BBO Consumptieve techniek - kok in de instelling

BBO Consumptieve techn.-indust.bewerk.pluimv/vlees

BBO Consumptieve techniek - horecamedewerker

BBO Consumptieve techniek - gastheer/gastvrouw

BBO Consumptieve techn.-prod.med. be-en verw. ind.

BBO Consumptieve techniek - bake-off bakker

BBO Consumptieve techn.- gezel-winkelbed. slagerij

BBO Consumptieve techniek - gezel-slager

BBO Consumptieve techniek - assistent chocolatier

BBO Consumptieve techniek - broodbakker grootbedr.

BBO Consumptieve techniek - broodbakken

BBO Consumptieve techniek - brood- en banketbakken

BBO Consumpt.techn.-rec. hotel- en verbl.recreatie

KMBO

KMBO consumptieve techniek

KMBO consumptieve techniek kok/kelner

KMBO consumptieve techniek brood en banket

KMBO horeca

KMBO Horeca - gastheer

KMBO Horeca - koken

MBO

MTO overig brood- en banketbakken (BB)

MMO horecaschool (MHS) 
MMO slagersvakschool

MMO bakkerij

Technisch: Grafische techniek

Leerlingwezen

BBO Grafisch - grafisch assistent afwerking

BBO Grafisch - voorbereiding

BBO Grafisch - drukken

BBO Grafisch - nabewerking

BBO Grafisch - grafisch assistent voorbereiding

BBO Grafisch - grafisch assistent drukken

BBO Grafisch - grafisch assistent nabewerking

BBO Grafisch - boekbinden

KMBO

KMBO grafische techniek

MBO

MTO overig grafische techniek (G)

MTO overig grafische techniek grafisch/technisch

MTO overig grafische techniek admin./economisch

MTO overig grafische techniek esthetisch/technisch

Technisch: overig

Leerlingwezen

BBO Bouwtechniek timmerkracht

BBO Bouwtechniek Betonmodelmaker

BBO Bouwtechniek betontimmerkracht

BBO Bouwtechniek betonstaalvlechter

BBO Bouwtechniek natuursteenbewerker

BBO Bouwtechniek ovenbouwmetselaar

BBO Bouwtechniek metselaar

BBO Bouwtechniek tegelzetter

BBO Bouwtechniek voeger

VSO/LOM

VSO/MLK

BBO Bouwtechniek hulpvakkracht op de bouwplaats

BBO Bouwtechniek dakdekker

BBO Bouwtechniek tegelzetter 
BBO Motorvoertuigentechniek - auto-elektricien

BBO Motorvoertuigentechniek - luchtv.gasturb.mont.

BBO Motorvoertuigentechniek - hulpmonteur automob.

BBO Motorvoertuigentechniek-monteur personenautom.

BBO Motorvoertuigentechniek-mont.bedr.automobiel.

BBO Motorvoertuigentech.-mont.pers.auto;mbt-schak.

BBO Motorvoertuigentechn.-mont.bedr.auto;mbt-schak

BBO Motorvoertuigentechniek - auto-elektricien

BBO Motorvoertuigentechniek - monteur tweewielers

BBO Motorvoertuigentechniek - monteur motorfietsen

BBO Motorvoertuigentechniek-revisiemont.motorvoert

BBO Motorvoertuigentechniek - monteur dieselmotor.

BBO Motorvoertuigentechniek-magazijnmed.motorvoert

BBO Motorvoertuigentechniek - hulpmonteur

BBO Motorvoertuigentechniek - monteur pers.automob

BBO Motorvoertuigentechniek - monteur bedrijfsauto

BBO Motorvoertuigentechniek-assemblagemont.autoind

BBO Motorvoertuigentechniek-aank.verkoper tankstat

BBO Motorvoertuigentechniek - auto-demonteur

BBO Verfappl.techn.- indust.schilder hout/meubel.

BBO Verfappl.techn.- industrieschilder: luchtvaart

BBO Verfappl.techn.-industrieschilder:metaalindust

BBO Verfappl.techn.- schilder

BBO Verfappl.techn.- stukadoor

BBO Verfappl.techn. - autospuiter

BBO Verfappl.techn. - autospuiter

BBO Verfappl.techn.-asp.vloerafw.tech \& betonrepar

BBO Verfappl.techn. - glaszetter

BBO Verfappl.techn. - wand- en plafondsystemen

BBO Verfappl.techn.-industrieschilder hout/meubel.

BBO Verfappl.techn.-industrieschilder: metaalind.

BBO Verfappl.techn.-industrieschilder: luchtvaart

BBO Verfappl.techn.-industrieschilder: vervoermid.

BBO Procestechniek - mechanisch operator A

BBO Procestechniek - mechanisch operator B

BBO Procestechniek - analist (chemische richting)

BBO Procestechniek - laborant (chemische richting)

BBO Procestechniek - procesoperator A

BBO Procestechniek - mechanisch operator A

$K M B O$

KMBO bouw \& houtbewerking 
KMBO bouw en houtbewerking metselen

KMBO bouw en houtbewerking timmeren

KMBO bouw en houtbewerking schilderen

KMBO motorvoertuigentechniek

KMBO procestechniek

MBO

MTS bouwkunde

MTS motorvoertuigentechniek

MTS motorvoertuigentechniek motorvoertuigen (MVT)

MTS motorvoertuigentechniek vervolgopleiding (VMVT)

MTS motorvoertuigentechniek vervolgopleiding (VBBM)

MTS Motorvoertuigentechniek -landbouwwerkt.techn.

MTO overig schildertechniek (S)

MTO overig schildertechniek (S) praktisch/esthet.

MTO overig schildertechniek (S) technisch/chemisch

MTO overig schildertechniek (S) commercieel/techn.

MTS procestechniek

Economisch \& administratief: Economisch \& administratieve beroepen

Leerlingwezen

BBO Ec. \& adm. ber. - adm. medewerker overheid

BBO Ec. \& adm. ber. - administratief medewerker

BBO Ec. \& adm. ber. - applicatiegebruiker

BBO Ec. \& adm. ber. - adm. medewerker overheid

BBO Ec. \& adm. ber. - administratief medewerker

$K M B O$

KMBO administratie

KMBO Administratie - spec. administratie

KMBO Administratie - spec. secretarieel

MBO

MEAO bedrijfsadministratief

MEAO

MEAO administratief commercieel

MEAO assurantie

MEAO commercieel/secretariaats

MEAO bedrijfsadministratief/bestuurlijk

MEAO administratief/secretariaats

MEAO Bank- en verzekeringswezen 


\section{Economisch \& administratief: Detailhandel}

Leerlingwezen

BBO Detailhandel Ass. verkoopmedewerker BBO Detailhandel Verkoopmedewerker

BBO Detailhandel - aank.verkoopmed. $\mathrm{k} / \mathrm{m} / \mathrm{g}$-bedrijf BBO Detailhandel - verkoopmedewerker $\mathrm{k} / \mathrm{m}$-bedrijf BBO Detailhandel - verkoopmedewerker g-bedrijf BBO Detailhandel - magazijnmedewerker groothandel BBO Detailhandel - Magazijnmedewerker groothandel BBO Detailhandel - aank. verkoopmedew. $\mathrm{k} / \mathrm{m} / \mathrm{g}$-bedr. BBO Detailhandel - verkoopmedewerker $\mathbf{k} / \mathrm{m}$-bedrijf BBO Detailhandel - verkoopmedewerker g-bedrijf

KMBO

KMBO detailhandel

MBO

MMO

MMO detailhandelschool

MMO detailhandelschool MMO-BD branchedifferentiatie

MMO detailhandelschool MMO-C

MMO detailhandelschool MMO-G (groothandel)

Verzorging \& dienstverlening

Verzorging \& dienstverlening: verzorgende en dienstverlenende beroepen BBO Verz. \& dienstverl.ber. - verzorgingsassistent BBO Verz. \& dienstverl.ber.- voedingsassistent BBO Verz. \& Dienstverl. ber. Leider Kindercentra BBO Verz.\& dienstverl.ber.-bejaardenh. verzorg.teh BBO Verz.\&dienstverl.ber.-help.bij inst.gezinsverz BBO Verz. \& Dienstverl. ber. Bej.verz. in tehuis BBO Verz. \& Dienstverl. Verz. inst. Gezinsverzorg. BBO Verz.\& dienstverl.ber.- beveiligingsbeambte

$K M B O$

KMBO verzorgende beroepen

$M B O$

MDGO verzorging $\mathrm{VZ}$

MDGO assistenten gezondheidszorg AG 
MDGO assistenten gezondheidszorg $A G$

MDGO assistenten gezondheidszorg AG/AA apoth.-ass.

MDGO assistenten gezondheidszorg AG/DA doktersass.

MDGO assistenten gezondheidszorg $A G / T A$ tandartsass

Verzorging \& dienstverlening: Haarkappen

Leerlingwezen

BBO Haarkappen - dameskapper

BBO Haarkappen - herenkappen

BBO Haarkappen - dames- en herenkapper

KMBO

KMBO uiterlijke verzorging

MBO

MDGO UV/BDH bediende dames/herenkappen

MDGO UV/HV haarverzorging

MDGO UVIOD ondernemer dameskappen

MDGO UV/OH ondernemer herenkappen

MDGO UVND vakbekwaamheid dameskappen

MDGO UVIVH vakbekwaamheid herenkappen

MDGO UVIVDH vakbekwaamheid dames- \& herenkappen 



\section{Appendix C Verbijzonderen van ROA arbeidsmarkt- prognoses voor het MBO/LLW}

\section{C1. Het bepalen van de beroepsdomeinen}

Om de prognoses van de uitbreidingsvraag naar schoolverlaters van het MBO/LLW uit het Informatiesysteem Onderwijs-Arbeidsmarkt te kunnen verbijzonderen naar een afzonderlijke vraag naar (K)MBO'ers en een afzonderlijke vraag voor LLWers moet worden bepaald welke ROA-beroepssegmenten relevant zijn voor het leerlingwezen en welke relevant zijn voor het $(\mathrm{K}) \mathrm{MBO}$.

Op basis van RUBS kan bepaald worden hoe de werkgelegenheid van (K)MBO'ers en LLWers over de ROA beroepssegmenten is verdeeld ${ }^{17}$. Het volgende selectiecriterium kan dan worden toegepast om te bepalen of een beroep relevant is voor het leerlingwezen of voor het (K)MBO.

Als geldt dat:

(1a) $\left(a_{i j k} /\right.$ bsg $\left._{i j}\right) /\left(\right.$ tota $_{i k} /$ tota $\left._{i}\right)>0,1$

en

(1b) $a_{i j k} /$ tota $_{i k}>\beta_{i}$

$i=1, \ldots, 29$

$\mathrm{j}=1, \ldots, 49$

$\mathrm{k}=\| \mathrm{w}, \mathrm{mbo}$

waar:

$a_{i j k}=$ aantal werkenden met opleidingstype $k$ en opleidingsrichting $i$ in beroepssegment $j$

$b s g_{i j}=$ totaal aantal werkenden met opleidingsrichting $i$ in beroepssegment $j$

tota $_{l k}=$ totaal aantal werkenden met opleidingstype $k$ en opleidingsichting $i$

tota $_{i}=$ totaal aantal werkenden met opleidingsrichting $i$

dan is beroepssegment $j$ relevant voor opleidingstype $k$ in opleidingsrichting $i$. Het aandeel van het beroepssegment in de totale werkgelegenheid voor het betreffende opleidingstype moet groter zijn dan een bepaalde drempelwaarde $\beta_{i}$. Het aandeel van het opleidingstype in de totale werkgelegenheid van het beroepssegment mag niet meer dan 10 keer zo klein zijn als het aandeel van het opleidingstype in de

17. Het gaat om (K)MBO-schoolverlaters en personen die nu een LLW-opleiding doen. 
totale werkgelegenheid voor de betreffende opleidingsrichting. Dat betekent dus dat als het aandeel van het leerlingwezen in de totale werkgelegenheid van de opleidingsrichting $50 \%$ is. Het aandeel van het leerlingwezen in het beroepssegment minimaal $5 \%$ moet zijn om relevant te zijn voor het leerlingwezen. Deze grens is vrij ruim genomen.

De beroepssegmenten kunnen nu op basis van genoemde criteria per opleidingsrichting in drie categorieën worden verdeeld, beroepen die alleen relevant zijn voor schoolverlaters uit het leerlingwezen ( $L L W$-domein), beroepen die alleen van belang zijn voor schoolverlaters van het KMBO en MBO (MBO-domein), beroepen die van belang zijn voor zowel schoolverlaters van het $(\mathrm{K}) \mathrm{MBO}$ als van het LLW (MBO/LLW domein).

Nu worden echter niet alle beroepen die relevant zijn voor het (K)MBO of leerlingwezen waargenomen. Omdat de verdeling van (K)MBO'ers en mensen met een leerlingwezen opleiding gebaseerd is op schoolverlatersinformatie worden de beroepen die niet direct relevant zijn voor schoolverlaters, maar die wel relevant zijn voor $(\mathrm{K}) \mathrm{MBO}$ ers en mensen met een leerlingwezenopleidng die al langer werkzaam zijn, buiten beschouwing gelaten ${ }^{18}$. Deze beroepen noemen we hier eindberoepen. Als een $(\mathrm{K}) \mathrm{MBO}^{\prime}$ er of iemand met een leerlingwezenopleiding die zich al langer op de arbeidsmarkt bevindt promotie naar een eindberoep maakt en dan ruimte maakt voor een schoolverlater in een beroepssegment waar schoolverlaters wel direct kunnen gaan werken leidt dit tot een positieve uitbreidingsvraag voor schoolverlaters. Omdat het aandeel van (K)MBO'ers en LLW'ers in deze beroepen niet bekend is kan niet vastgesteld worden of het beroep relevant is voor alleen (K)MBO'ers, voor alleen LLW'ers of voor beiden. Als de eindberoepen niet in beschouwing worden genomen dan wordt ten onrechte een deel van de vraag naar (K)MBO'ers en LLW'ers niet meegeteld.

Dit probleem kan worden opgelost door de vervangingsvraag voor schoolverlaters van het $\mathrm{MBO} / \mathrm{LLW}$ te bepalen op basis van de vervangingsvraag vanuit het $M B O$-, $L L W$ - en het $M B O / L L W$-beroepsdomein ${ }^{19}$. De vervangingsvraag per opleidingsrichting $i$ vanuit beroepsdomein / wordt als volgt bepaald:

18. De verdeling van schoolverlaters over de beroepssegmenten wijkt dus af van de verdeling van de totale beroepsbevolking over de beroepssegmenten. De ROA-arbeidsmarktprognoses gaan wel uit van de verdeling van alle werkenden met een bepaalde opleidingsachtergrond (zie Borghans e.a., 1995).

19. De vervangingsvraag per opleiding komt dan niet overeen met de vervangingsvraag zoals gepresenteerd in ROA, 1995a,b. 


$$
W_{i}^{\prime}=\sum j_{\epsilon_{t}} a_{i j} / b k l_{j} \times W_{j}
$$

waar:

$1=\| l w, m b o, m b o / l w$

$a_{i j}=$ aantal werkenden met opleidingsrichting $i$ in beroepsklasse $j$.

$b k l_{j}=$ totaal aantal werkenden in beroepsklasse $j$

$W_{j}=$ vervangingsvraag vanuit beroepklasse $j$

Nu wordt in tegenstelling tot in het ROA-Informatiesysteem Onderwijs-Arbeidsmarkt baan-baan-mobiliteit tussen beroepen wel meegeteld als vervangingsvraag voor een opleiding $^{20}$. Waarbij overigens wel verondersteld is dat de baan-baan-mobiliteit binnen een een bepaalde beroepsdomein I te verwaarlozen is. Ook wordt verondersteld dat de opleidingsstructuur van een beroepsklasse constant is. Dat betekent dat als iemand met een bepaalde opleiding uit een beroep stroomt, hij wordt vervangen door iemand met dezelfde opleiding. Het aantal baanopeningen voor opleidingsrichting $i$ vanuit beroepsdomein / wordt gegeven door:

$B A A N_{i}^{\prime}=U V_{i}^{\prime}+W V_{i}^{\prime}$

Het bovenstaande wordt duidelijker met behulp van figuur C1. Er is een groep beroepen waarin schoolverlaters direkt naar het verlaten van de opleiding gaan werken, de startberoepen en een groep beroepen waarin men pas met enige tijd werkervaring kan gaan werken, de eindberoepen. De startberoepen worden in RUBS waargenomen, de overige beroepen waarin (K)MBO'ers en LLW'ers werkzaam zijn vormen de eindberoepen.

In de eindberoepen is sprake van een uitbreidingsvraag, $U V_{3}$, en een vervangingsvraag $W_{3}$. Deze vraag wordt vervuld door mensen aan te trekken vanuit de startberoepen. De vervangingsvraag vanuit de startberoepen is daarom gelijk aan de oorspronkelijke vervangingsvraag vanuit deze beroepen plus de totale vraag (uitbreidingsvraag en vervangingsvraag) vanuit de eindberoepen. De totale vraag vanuit de startberoepen wordt opgevuld door schoolverlaters. In het ROA informatiesysteem wordt het aantal baanopeningen voor schoolverlaters bepaald als $U V_{1}+U V_{3}+W_{1}+W_{3}$ Het aantal baanopeningen op basis van alleen de startberoepen wordt bepaald door

20. De ROA-beroepssegmenten kunnen verder uitgesplitst worden naar ROA-beroepsklassen. De vervangingsvraag per beroepsdomein (LLW, MBO, MBL/LLW) wordt bepaald op basis van de vervangingsvraag per beroepsklasse. Een beroepsklasse wordt dan tot hetzelfde beroepsdomein gerekend als het beroepssegment waar deze beroepsklasse onder valt. De uitbreidingsvraag per beroepsdomein wordt wel bepaald op basis van de uitbreidingsvraag per beroepssegment (zie Borghans e.a., 1995). 
$U V_{1}+W_{1}^{*}$. In principe zou het aantal baanopeningen voor (K)MBO'ers en LLW'ers dus kunnen worden bepaald door alleen te kijken naar beroepssegmenten die relevant zijn voor schoolverlaters. Immers $U V^{1}+W^{1 *}=U V^{1}+U V^{3}+W^{1}+W W^{3}$

Figuur C1

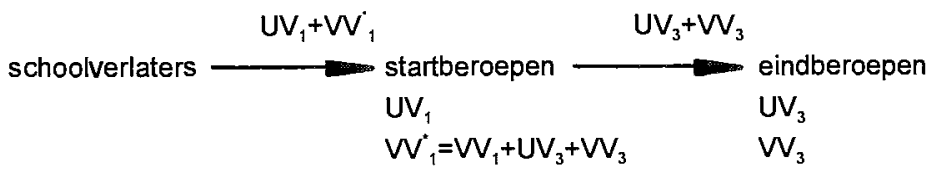

In werkelijkheid zal er echter ook een groep beroepen bestaan waarin zowel schoolverlaters als mensen die zich al langer op de arbeidsmarkt bevinden kunnen instromen: de doorstroomberoepen.

Figuur $\mathrm{C} 2$

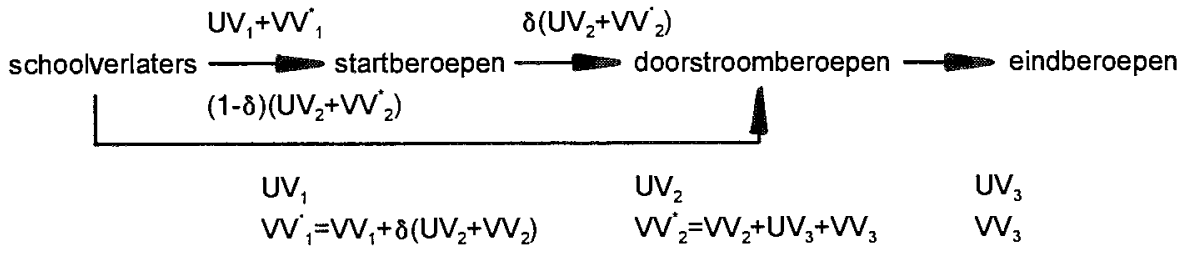

De totale vraag vanuit de eindberoepen wordt alleen opgevuld door mensen die voorheen in een doorstroomberoep werkzaam waren. Een deel, $\delta$, van de vraag vanuit de doorstroomberoepen wordt opgevuld door schoolverlaters en een deel $(1-\delta)$ van de vraag wordt opgevuld door personen die voorheen werkzaam waren in een startberoep. Het aantal baanopeningen voor schoolverlaters is nu: $U V_{1}+W_{1}^{*}+(1-\delta)\left(U V_{2}+W_{2}^{*}\right)$

Als nu ten onrechte een doorstroomberoep tot de eindberoepen worden gerekend, dan wordt het aantal baanopeningen voor schoolverlaters onderschat: $\left(U V_{1}+W_{1}^{*}\right)$

Als daarentegen wordt aangenomen dat een doorstroomberoep een startberoep is dan wordt het aantal baanopeningen voor schoolverlaters overschat: $\left(U V_{1}+U V_{2}+W_{1}^{*}+W V_{2}^{*}\right)$

Het probleem is nu deze doorstroomberoepen te identificeren en de waarde van $\delta$ te bepalen. Door per opleidingsrichting MBO/LLW de $\beta_{i}$ te variëren in het selectiecriterium (1b) kunnen de doorstroomberoepen worden bepaald. 
$\beta_{i}^{*}$ is de laagste waarde van $\beta_{i}$ waarvoor geldt:

$B A A N_{i}^{\text {roa }}<B A A N_{i}^{m b o}+B A A N_{i}^{l l w}+B A A N_{i}^{m b o l l w}$

en $\beta_{i}^{* *}$ is de hoogste waarde van $\beta_{i}$ waarvoor geldt:

$B A A N_{i}^{\text {rog }}>B A A N_{i}^{m b o}+B A A N_{i}^{l l w}+B A A N_{l}^{m b o l l w}$

$B A A N_{i}^{r o g}$ is het totaal aantal baanopeningen voor MBO/LLW opleidingsrichting $i$ volgens de ROA-arbeidsmarktprognoses (ROA, 1995, a,b), $B A A N_{i}^{m b o}$ is het aantal baanopeningen vanuit het $M B O-d o m e i n, B A A N_{i}^{l i W}$ het aantal baanopeningen vanuit het $L L W$-domein en $B A A N_{i}^{\text {mbollw }}$ het aantal baanopeningen vanuit het $M B O / L W$ beroepsdomein.

De beroepen die worden geselecteerd voor $\beta_{i}=\beta_{i}^{* *}$ vormen de startberoepen en beroepen die niet worden geselecteerd als $\beta_{i}=\beta_{i}^{* *}$ maar wel als $\beta_{i}=\beta_{i}^{*}$ vormen de doorstroomberoepen. 8 wordt nu zo gekozen dat geldt:

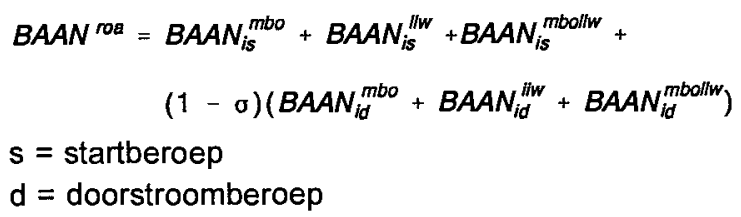

$\beta_{i}^{*}$ en $\beta_{i}^{* *}$ kunnen echter niet analytisch worden bepaald omdat als de uitbreidingsvraag voor een bepaalde beroepsdomein negatief is de vraag wordt aangevuld vanuit de overige beroepsdomeinen en worden daarom bepaald door middel van 'trial and error'21.

Voor enkele opleidingsrichtingen geldt dat als $\beta_{i}=0$

$B A A N_{i}^{\text {roa }}>B A A N_{i}^{\text {mbo }}+B A A N_{i}^{l l w}+b a a n_{i}^{\text {mbollww }}$.

21. In het ROA-informatiesysteem wordt verondersteld dat als iemand met een bepaalde opleiding zijn baan verliest hij kan uitwijken naar een ander beroepssegment waar de uitbreidingsvraag voor zijn opleiding positief is. Pas als de totale uitbreidingsvraag voor een opleiding negatief is raken mensen met die opleiding werkloos. Als er dus in éen of meer van de drie onderscheiden beroepsdomeinen sprake is van een negatieve uitbreidingsvraag terwijl de totale uitbreidingsvraag voor de betreffende opleidingsrichting positief is dan wordt het verschil van de positieve en negatieve uitbreidingsvraag verdeeld over de beroepsdomeinen met een negatieve uitbreidingsvraag. 
Het totaal aantal baanopeningen op basis van de startberoepen wordt dus onderschat. Dat kan betekenen dat er beroepssegmenten zijn die wel relevant zijn voor schoolverlaters uit deze richtingen maar die niet in RUBS voorkomen.

Ook blijkt dat in een aantal gevallen de vervangingsvraag vanuit de verschillende beroepsdomeinen wordt onderschat. Dat gebeurt bijvoorbeeld als schoolverlaters vanuit een bepaalde opleidingsrichting pas recent in een bepaald beroep zijn gaan werken. Echter, ook als de vervangingsvraag wordt bepaald op basis van de opleidingenstructuur voor werkzame personen die jonger zijn dan 25 jaar blijft dat probleem voor een aantal opleidingsrichtingen bestaan. Kennelijk spelen hier toch andere factoren een rol. Voor opleidingsrichtingen waar het aantal baanopeningen werd onderschat is daarom de vervangingsvraag vanuit de verschillende beroepsdomeinen evenredig opgehoogd. Dat is gebeurd bij de opleidingsrichtingen MBO/LLW consumptieve techniek, MBO/LLW textiel en ledertechniek, MBO/LLW haven en vervoer en MBO/LLW handel.

\section{C2 Confrontatie van vraag en aanbod}

Het aanbod van schoolverlaters is weliswaar opgesplitst naar een LLW en (K)MBO component maar een deel van de vraag is voor zowel MBO'ers als LLW'ers bestemd (de vraag vanuit het MBO/LLW domein). De vraag is dus niet altijd duidelijk afgebakend naar opleidingstype (MBO of LLW). Er moeten daarom veronderstellingen worden gemaakt over de voorkeur van werkgevers voor (K)MBO'ers of LLW'ers. Deze voorkeur kan verschillen per opleidingsrichting.

Er kunnen drie situaties bestaan:

1. Werkgevers hebben altijd een voorkeur voor MBO'ers en KMBO'ers

In dat geval is de vraag naar (K)MBO'ers gelijk aan de vraag vanuit het $M B O-$ domein en de vraag vanuit het $M B O / L L W$ domein. De vraag naar mensen die een opleiding in het leerlingwezen hebben voltooid is dan gelijk aan de vraag vanuit het $L L W$-domein plus de vraag vanuit het $M B O / L L W$-domein minus het aanbod van (K)MBO'ers voor het $M B O / L L W$ domein. Dus

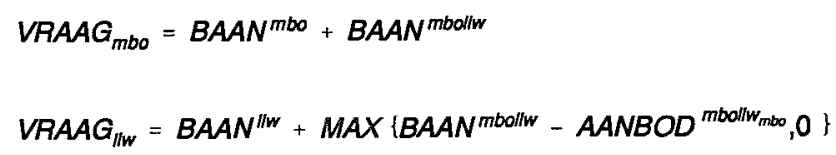

Waar:

$A A N B O D_{m b o}^{\text {mbollw }}=$ Het aanbod van MBO'ers op het gezamenlijke domein:

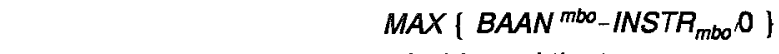

${I N S T R_{k}} \quad=\quad$ arbeidsmarktinstroom van schoolverlaters met opleiding $k, k=m b o, l l w$ 


$\begin{array}{lll}V R A A G_{k} & = & \begin{array}{l}\text { totale vraag naar schoolverlaters met opleidingstype } \mathrm{k}, \\ \mathrm{k}=\mathrm{mbo}, \mathrm{llw}\end{array} \\ B A A N^{\prime} & = & \begin{array}{l}\text { baanopeningen vanuit beroepsdomein I, I=mbo,llw, } \\ \text { mbollw }\end{array}\end{array}$

2. Werkgevers hebben altijd een voorkeur voor mensen met een leerlingwezen opleiding

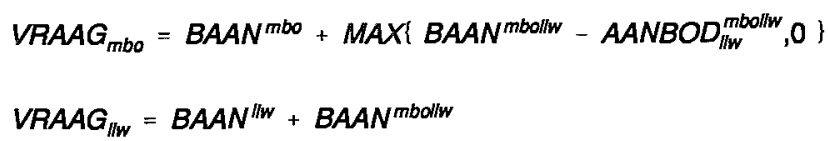

3. Werkgevers hebben geen voorkeur

In dat geval hebben (K)MBO'ers en LLW'ers gelijke kansen op een baan, de vraag naar (K)MBO'ers en mensen die een leerlingwezenopleiding hebben gevolgd wordt dan:

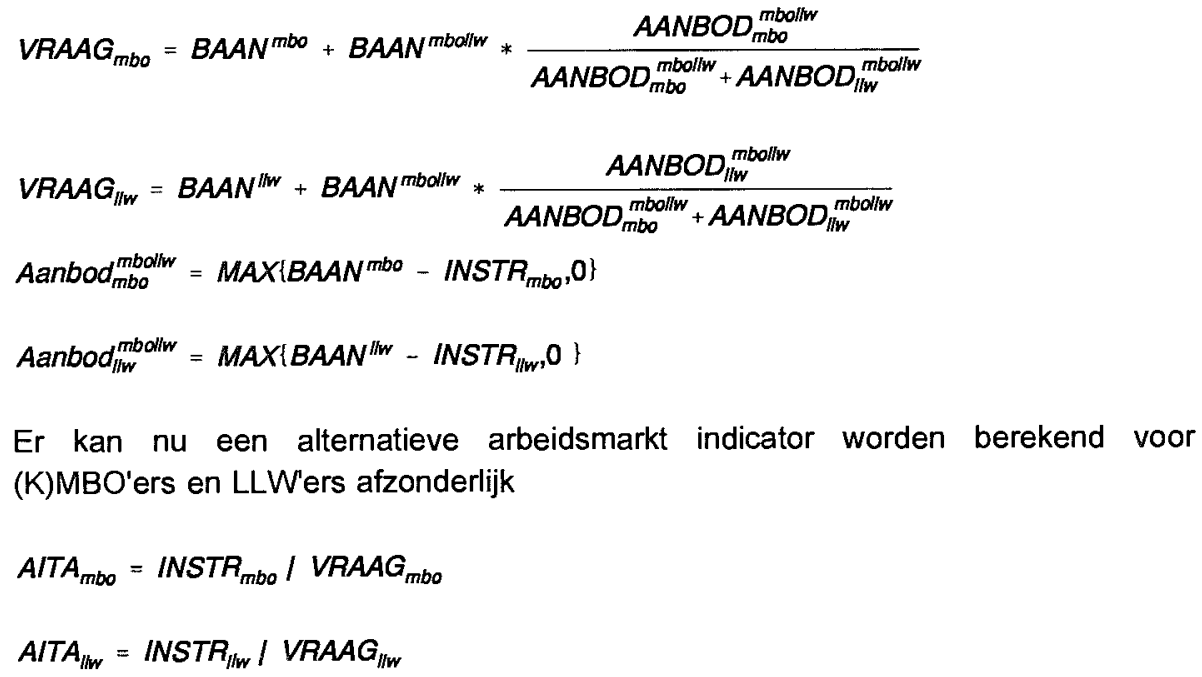

Er kan nu een alternatieve arbeidsmarkt indicator worden berekend voor (K)MBO'ers en LLW'ers afzonderlijk

$A I T A_{m b o}=I N S T R_{m b o} / V R A A G_{m b o}$

$A I T A_{l l w}=I N S T R_{l / w} / V R A A G_{l l w}$

Deze alternatieve indicator toekomstige arbeidsmarktperspectief (AITA) verschilt op verschillende punten van de Indicator toekomstig arbeidsmarktperspectief (ITA) die wordt gepresenteerd in De arbeidsmarkt naar opleiding en beroep tot 2000 (ROA, $1995 a, b)$. De AITA is gedefinieerd als verhouding tussen de instroom en vraag. $\mathrm{Bij}$ de ITA worden de vraag en aanbod prognoses echter gerelateerd aan de omvang van de werkzame beroepsbevolking met de betreffende opleidingsachtergrond. Bij de AITA gebeurt dat niet omdat deze cijfers niet bekend zijn voor het (K)MBO en leerlingwezen afzonderlijk. Verder wordt bij het bepalen van de ITA, ook de kortdurende werkloosheid bij het aanbod gerekend. De evenwichtswaarde (als de vraag gelijk is aan het aanbod) van de AITA ligt daarom lager dan van de ITA. De 
arbeidsmarktperspectieven voor leerlingwezen en (K)MBO worden getypeerd op basis van de volgende indeling:

\begin{tabular}{|c|c|c|c|c|c|}
\hline & & AITA & $<$ & 0,95 & goed \\
\hline 0,95 & $\leq$ & AITA & $<$ & 1,20 & redelijk \\
\hline 1,20 & $\leq$ & AITA & $<$ & 2,00 & matig \\
\hline 2,00 & $\leq$ & AITA & & & slecht \\
\hline
\end{tabular}




\title{
Appendix D De beroepsdomeinen
}

Tabel D.1

Beroepsdomeinen MBO/LLW landbouw en natuurlijke omgeving

\author{
LLW-domein \\ MBO-domein \\ middelbare technische, ambachts- en industrieberoepen \\ lagere voedings- en genotmiddelenberoepen \\ lagere transportberoepen \\ hogere medische en paramedische beroepen \\ middelbare administratieve beroepen
}

MBO/LLW-domein

middelbare kunst- en vormgevende beroepen

lagere agrarische beroepen

lagere commerciële beroepen

Tabe/ D. 2

Beroepsdomeinen MBO/LLW bouwkunde

\section{LLW-domein}

MBO-domein

middelbare technische, ambachts- en industrieberoepen

middelbare bouw- en installatieberoepen

lagere transportberoepen

middelbare administratieve beroepen

lagere commerciële beroepen

MBO/LLW-domein

lagere hout- en papierberoepen

lagere bouw- en installatieberoepen

Tabel D.3

Beroepsdomeinen MBO/LLW weg- en waterbouwkunde

LLW-domein

lagere technische, ambachts- en industrieberoepen

MBO-domein

middelbare technische, ambachts- en industrieberoepen

middelbare bouw- en installatieberoepen

MBO/LLW-domein

lagere bouw- en installatieberoepen 
Tabel D.4

Beroepsdomeinen MBO/LLW metaalkunde

\section{LLW-domein}

MBO-domein

middelbare technische, ambachts- en industrieberoepen

middelbare metaalberoepen

lagere transportberoepen

lagere rail- en wegtransportberoepen

middelbare administratieve beroepen

MBO/LLW-domein

lagere metaalberoepen

middelbare electrotechnische beroepen

lagere bouw- en installatieberoepen

Tabel D.5

Beroepsdomeinen MBO/LLW fijnmechanische techniek

\section{LLW-domein}

MBO-domein

lagere commerciele beroepen

middelbare commerciele beroepen

\section{MBO/LLW-domein}

middelbare technische, ambachts- en industrieberoepen

lagere hout- en papierberoepen

lagere metaalberoepen

middelbare metaalberoepen

middelbare electrotechnische beroepen 
Tabel D.6

Beroepsdomeinen MBO/LLW werktuigbouwkunde

\section{LLW-domein}

MBO-domein

middelbare technische, ambachts- en industrieberoepen

middelbare metaalberoepen

lagere transportberoepen

lagere rail- en wegtransportberoepen

middelbare administratieve beroepen

lagere commerciele beroepen

MBO/LLW-domein

lagere metaalberoepen

middelbare electrotechnische beroepen

lagere bouw- en installatieberoepen

Tabel D.7

Beroepsdomeinen MBO/LLW motorvoertuigentechniek

LLW-domein

MBO-domein

middelbare administratieve beroepen

lagere commerciele beroepen

MBO/LLW-domein

lagere metaalberoepen

middelbare metaalberoepen

Tabel D.8

Beroepsdomeinen MBO/LLW elektrotechniek

\section{LLW-domein}

lagere electrotechnische beroepen

MBO-domein

middelbare technische, ambachts- en industrieberoepen

lagere metaalberoepen

lagere commerciele beroepen

MBO/LLW-domein

middelbare electrotechnische beroepen 
Tabel D.9

Beroepsdomeinen MBO/LLW grafische techniek

\section{LLW-domein}

MBO-domein

middelbare technische, ambachts- en industrieberoepen

middelbare administratieve beroepen

middelbare commerciele beroepen

hogere sociaal-culturele beroepen

MBO/LLW-domein

middelbare kunst- en vormgevende beroepen

lagere grafische beroepen

Tabe/ D.10

Beroepsdomeinen MBO/LLW consumptieve techniek

LLW-domein

lagere voedings- en genotmiddelenberoepen

lagere commerciele beroepen

MBO-domein

MBO/LLW-domein

middelbare medische en paramedische beroepen

Tabel D.11

Beroepsdomeinen MBO/LLW procestechniek

LLW-domein

lagere hout- en papierberoepen

MBO-domein

lagere metaalberoepen

MBO/LLW-domein

lagere chemische beroepen

lagere electrotechnische beroepen 
Tabel D. 12

Beroepsdomeinen MBO/LLW textiel- en ledertechniek

\section{LLW-domein}

MBO-domein

middelbare kunst- en vormgevende beroepen

middelbare administratieve beroepen

lagere horecaberoepen

lagere verzorgende beroepen

MBO/LLW-domein

lagere textielberoepen

lagere commerciële beroepen

Tabe/ D.13

Beroepsdomeinen MBO/LW haven en vervoer

LLW-domein

lagere rail- en wegtransportberoepen

MBO-domein

middelbare technische, ambachts- en industrieberoepen

middelbare maritieme e.a. waterwegtransportberoepen

MBO/LLW-domein

lagere technische, ambachts- en industrieberoepen

lagere voedings- en genotmiddelenberoepen

lagere metaalberoepen

middelbare metaalberoepen

lagere bouw- en installatieberoepen

lagere transportberoepen

lagere maritieme e.a. waterwegtransportberoepen

middelbare administratieve beroepen

lagere commerciele beroepen 
Tabel D.14

Beroepsdomeinen MBO/LLW medisch laboratorium

\section{LLW-domein}

lagere metaalberoepen

middelbare medische en paramedische beroepen

MBO-domein

middelbare technische, ambachts- en industrieberoepen

middelbare administratieve beroepen

MBO/LLW-domein

hogere medische en paramedische beroepen

Tabel D. 15

Beroepsdomeinen MBO/LLW handel

LLW-domein

MBO-domein

lagere rail- en wegtransportberoepen

lagere administratieve beroepen

middelbare commerciele beroepen

lagere horecaberoepen

lagere verzorgende beroepen

MBO/LLW-domein

lagere agrarische beroepen

lagere voedings- en genotmiddelenberoepen

lagere hout- en papierberoepen

lagere bouw- en installatieberoepen

lagere transportberoepen

middelbare administratieve beroepen

lagere commerciële beroepen

Tabel D.16

Beroepsdomeinen MBO/LLW administratief

LLW-domein

hogere administratieve beroepen

MBO-domein

lagere transportberoepen

middelbare commerciële beroepen

MBO/LLW-domein

lagere administratieve beroepen

middelbare administratieve beroepen

lagere commerciele beroepen 
Tabel D.17

Beroepsdomeinen MBO/LLW secretarieel

LLW-domein

MBO-domein

MBO/LLW-domein

middelbare administratieve beroepen

Tabel D.18

Beroepsdomeinen MBO/LLW verzorging

LLW-domein

lagere horecaberoepen

middelbare verzorgende beroepen

MBO-domein

middelbare medische en paramedische beroepen

lagere commerciële beroepen

hogere sociaal-culturele beroepen

MBO/LLW-domein

lagere verzorgende beroepen 
